\title{
ESTUDO DOS LIXIVIADOS DAS FRAÇÕES DO ATERRO SANITÁRIO DE SÃO CARLOS - SP POR MEIO DA CARACTERIZAÇÃO FÍSICO-QUÍMICA
}

ADRIANA GONÇALVES FERREIRA

Dissertação apresentada à Escola de Engenharia de São Carlos da Universidade de São Paulo para Obtenção do título de mestre em Ciências

Orientador: Prof. Assoc. Valdir Schalch

São Carlos 2010 
AUTORIZO A REPRODUÇÃO E DIVULGAÇÃO TOTAL OU PARCIAL DESTE TRABALHO, POR QUALQUER MEIO CONVENCIONAL OU ELETRÔNICO, PARA FINS DE ESTUDO E PESQUISA, DESDE QUE CITADA A FONTE.

Ficha catalográfica preparada pela Seção de Tratamento da Informação do Serviço de Biblioteca - EESC/USP

\begin{tabular}{|c|c|}
\hline \multirow[t]{3}{*}{ F383e } & $\begin{array}{l}\text { Ferreira, Adriana Gonçalves } \\
\text { Estudo dos lixiviados das frações do aterro } \\
\text { sanitário de São Carlos-SP por meio da caracterização } \\
\text { físico- química / Adriana Gonçalves Ferreira ; } \\
\text { orientador Valdir Schalch. -- São Carlos, } 2010 .\end{array}$ \\
\hline & $\begin{array}{l}\text { Dissertação (Mestrado-Programa de Pós-Graduação e } \\
\text { Área de Concentração em Ciências da Engenharia } \\
\text { Ambiental) -- Escola de Engenharia de São Carlos da } \\
\text { Universidade de São Paulo, } 2010 \text {. }\end{array}$ \\
\hline & $\begin{array}{l}\text { 1. Resíduos sólidos. 2. Lixiviados de aterros } \\
\text { sanitários. 3. Caracterização físico-química. I. } \\
\text { Título. }\end{array}$ \\
\hline
\end{tabular}




\section{FOLHA DE JULGAMENTO}

\section{Candidato(a): Engenheira ADRIANA GONÇALVES FERREIRA}

Dissertação defendida e julgada em 14/05/2010 perante a Comissão Julgadora:
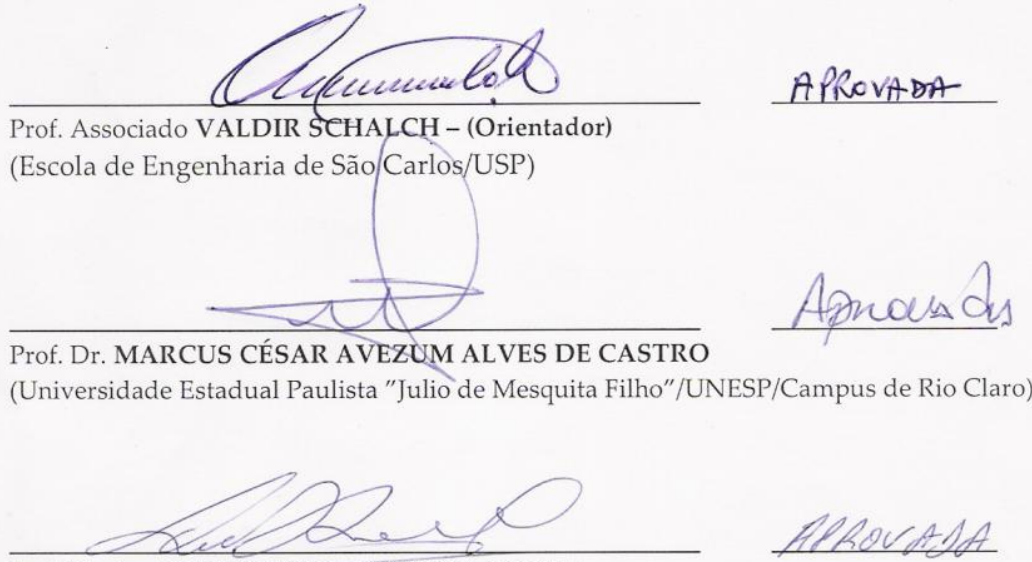

Prof. Titular ARISTIDES DE ALMEIDA ROCHA

(Faculdade de Saúde Pública/USP)
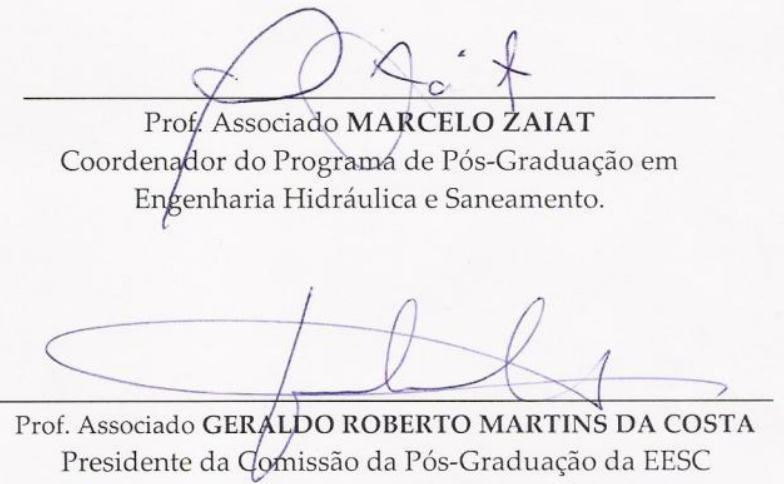
Página intencionalmente deixada em branco 
Aos meus pais Douglas e Eutália e a meus irmãos Heloísa e Gabriel que sempre me apoiaram em todos os momentos. 


\section{AGRADECIMENTOS}

A Deus pelo dom da vida.

Ao Prof. Dr. Valdir Schalch pela orientação e amizade cultivada durante este trabalho.

Ao Prof. Dr. Marcus César Avezum Alves de Castro pelas sugestões dispensadas na realização de meu trabalho.

Ao Dr. Ronan Cléber Contrera, que praticamente me co-orientou nesta pesquisa, sempre disponível a esclarecer os mais diversos questionamentos.

Ao CNPq e Capes pelas bolsas de estudo concedidas.

À Prefeitura Municipal de São Carlos, na pessoa do Sr. Douglas Minamisako, que autorizou minhas entradas no aterro sanitário municipal e forneceu um histórico de operações da área.

À Vega Engenharia Ambiental, através do Sr. Fábio Andrade, pelas fotos aéreas e informações sobre o aterro sanitário.

Às secretárias do SHS: Rose, Sá e Pavi pela ajuda sempre que necessária.

Aos técnicos e técnicas do Laboratório de Saneamento: Paulo, Júlio, Juliana e Natália por todo carinho e dedicação em me orientar nas análises.

Ao Fernando, pela ajuda nas coletas e na finalização desta dissertação.

Aos colegas, amigos e familiares que contribuíram na realização deste trabalho. 
FERREIRA, A.G. (2010) Estudo dos lixiviados das frações do aterro sanitário de São Carlos - SP por meio da caracterização físico-química. São Carlos-SP, 2010, 134 p., Dissertação de Mestrado - Escola de Engenharia de São Carlos, Universidade de São Paulo.

Este trabalho teve como objetivo determinar as fases de decomposição das frações dos resíduos dispostos no aterro sanitário de São Carlos - SP a partir do estudo das características dos lixiviados gerados. Foram coletadas amostras do lixiviado gerado na parte mais antiga do aterro (encerrada a 10 anos) e nas $1^{\mathrm{a}}, 2^{\mathrm{a}}$ e $3^{\mathrm{a}}$ ampliações (esta última em operação). A coleta foi dividida em dois períodos: seco (junho a setembro de 2009) e chuvoso (outubro a dezembro de 2009). As seguintes análises foram realizadas: $\mathrm{pH}$, alcalinidade, ácidos voláteis totais, DQO, sólidos, metais, NTK e N amoniacal. Em todos pontos os valores de $\mathrm{pH}$ encontrados foram superiores a 8 . A alcalinidade variou entre 4000 e $12000 \mathrm{mg} / \mathrm{LCaCO}_{3}$ enquanto os AVT apresentaram concentrações sempre inferiores a $700 \mathrm{mg} / \mathrm{LCaCO}_{3}$. A DQO apresentou concentrações entre 3000 e 7000 $\mathrm{mg} / \mathrm{L}$ durante o período seco, decaindo para 2000 e $4000 \mathrm{mg} / \mathrm{L}$ no período chuvoso. Os resultados encontrados sugerem que o lixiviado de todos os pontos encontram-se na fase metanogênica de decomposição da matéria orgânica. A partir dos resultados de NTK e $\mathrm{N}$ amoniacal ficou evidente que a amônia é o poluente presente em maior concentração no lixiviado - corresponde a mais de $70 \%$ do NTK. A biodegradabilidade foi investigada através das relações AVT/DQO e STV/ST e resultaram em valores menores que 0,25 e 0,3 respectivamente, indicando que o lixiviado do aterro de São Carlos possui baixa biodegradabilidade.

Palavras-chave: Resíduos sólidos, Lixiviados de aterros sanitários, Caracterização físico-química. 


\begin{abstract}
FERREIRA, A.G. (2010) Study from de leachate of fractions from São Carlos landfill - SP through the physicochemical characterization. São Carlos-SP, 2010, 134 p., Master Dissertation - São Carlos Engineering School, São Paulo University.

This work aimed to determine the stages of the decomposition of the waste disposed in São Carlos - SP landfill fractions through the study of the characteristics of the generated leachate. Samples were collected from the older area of the landfill (closed 10 years ago), and also from the first, second and third new built areas (garbage is still being dumped in the third one). The samples were collected in two periods: the dry one (from June to September 2009) and the rainy one (from October to December 2009). The concentration of $\mathrm{pH}$, alkalinity, total volatile acids, COD, solids, metals, sodium and potassium, total nitrogen and ammonium-N were determined in the study. In all the points sampled the values of $\mathrm{pH}$ were higher than 8 . The alkalinity ranged from 4000 $\mathrm{mg} / \mathrm{L}$ to $12000 \mathrm{mg} / \mathrm{L} \mathrm{CaCO}_{3}$, while the total volatile acids concentrations were less than $700 \mathrm{mg} / \mathrm{L} \mathrm{CaCO}_{3}$. The COD present concentrations between 3000 e $7000 \mathrm{mg} / \mathrm{L}$ in the dry period decaying to 2000 and $4000 \mathrm{mg} / \mathrm{L}$ in the rainy period. The results found suggest that all the leachate analyzed is in the methanogenic phase of the organic matter. From the total nitrogen and ammonium $\mathrm{N}$ results it turned out to be evident that ammonia is the major pollutant present in the leachate - more than $70 \%$ of the total nitrogen. The biodegradability was investigated through the relations VFA/COD and VS/TS and resulted in values lower than 0,25 and 0,3 respectively, indicating that the leachate from São Carlos landfill has low biodegradability.
\end{abstract}

Key words: Solids wastes, Landfill leachates, Physicochemical characterization. 


\section{LISTA DE FIGURAS}

FIGURA 3.1.2.1: Distribuição da disposição final dos resíduos sólidos urbanos.......

FIGURA 3.1.2.2: Posição da Divisão de Gestão de Resíduos Sólidos no organograma da Prefeitura......

FIGURA 3.2.1.1: Desenvolvimento de um aterro sanitário (a) escavação e instalação do liner, (b) disposição dos resíduos no aterro, e (c) encerramento do aterro.

FIGURA 3.2.1.2: Detalhe do coletor de gases......

FIGURA 3.2.2.1: Variações de parâmetros selecionados, indicadores das fases de estabilização da matéria orgânica em um aterro sanitário.

FIGURA 3.3.3.1.1: Dinâmica de água na formação de lixiviado em um aterro.

FIGURA 4.1.1: Foto aérea do aterro de São Carlos

FIGURA 4.1.2: Áreas do aterro sanitário de São Carlos.

FIGURA 4.2.1: Instalações do aterro sanitário de São Carlos em 2009.

FIGURA 4.2.2: Caixa de passagem 2.....

FIGURA 4.2.3: Lixiviado sendo coletado no aterro.

FIGURA 4.2.4: Coletor utilizado durante as coletas.

FIGURA 4.5.1: Localização da estação pluviométrica em relação ao aterro sanitário

FIGURA 5.1.1: Comportamento do $\mathrm{pH}$

FIGURA 5.2.1: Comportamento da alcalinidade 68

FIGURA 5.3.1: Comportamento do AVT............................................................. 70

FIGURA 5.4.1: Comportamento da DQO............................................................ 73

FIGURA 5.5.1: Comportamento do NTK............................................................ 74

FIGURA 5.6.1: Comportamento do $\mathrm{N}$ amoniacal................................................. 76

FIGURA 5.7.1: Comportamento do ST .................................................................. 78

FIGURA 5.7.2: Comportamento do STF............................................................... 79

FIGURA 5.7.3: Comportamento do STV ............................................................ 80

FIGURA 5.8.1: Comportamento do SST........................................................... 81

FIGURA 5.8.2: Comportamento do SSF............................................................. 82

FIGURA 5.8.3: Comportamento do SSV ............................................................ 83

FIGURA 5.9.1: Comportamento do chumbo......................................................... 84 
FIGURA 5.9.2: Comportamento do cádmio......................................................... 85

FIGURA 5.9.3: Comportamento do níquel........................................................... 86

FIGURA 5.9.4: Comportamento do ferro............................................................. 87

FIGURA 5.9.5: Comportamento do cobre......................................................... 89

FIGURA 5.9.6: Comportamento do cromo......................................................... 90

FIGURA 5.9.7: Comportamento do sódio............................................................. 91

FIGURA 5.9.8: Comportamento do potássio........................................................... 92 


\section{LISTA DE TABELAS}

TABELA 3.1.1.1: Composição física dos resíduos sólidos da cidade de São Carlos - SP.

TABELA 3.3.2.1: Composição típica de lixiviados de aterros jovens e velhos

TABELA 3.3.2.2: Características mais prováveis do lixiviado de aterros brasileiros.

TABELA 3.3.2.3: Ácidos Voláteis e suas principais características.

TABELA 3.3.4.1: Limites máximos permitidos de concentração de metais para lançamento em corpos d’água.

TABELA 3.3.4.2: Concentrações de metais pesados em lixiviados

TABELA 4.4.1: Variáveis analisadas e métodos de análise do lixiviado. 62

TABELA 4.5.1: Histórico das operações do aterro. 63

TABELA 4.5.2: Quantidade de resíduos aterrada durante os anos. 64

TABELA 5.3.1: Valores corrigidos de AVT no período seco 71

TABELA 5.3.2: Valores corrigidos de AVT no período chuvoso. 72

TABELA 5.6.1: Porcentagem média do N-amoniacal em relação ao NTK e valores de N-orgânico para o período seco 77

TABELA 5.10.1: Valores da relação AVT/DQO para o período seco...................... 94

TABELA 5.10.2: Valores da relação AVT/DQO para o período chuvoso................ 94

TABELA 5.10.3: Relação STV/ST para o período seco............................................ 95

TABELA 5.10.4: Relação STV/ST para o período chuvoso..................................... 96

TABELA B.1: Valores de pH no período seco..................................................... 115

TABELA B.2: Valores de pH no período chuvoso............................................... 115

TABELA B3: Valores de alcalinidade no período seco (valores em mg/ $\mathrm{LCaCO}_{3}$ ).. 116

TABELA B4: Valores de alcalinidade no período chuvoso (valores em $\left.\mathrm{mg} / \mathrm{LCaCO}_{3}\right)$

TABELA B5: Valores de ácidos voláteis totais (AVT) no período seco (valores em $\left.\mathrm{mg} / \mathrm{LCaCO}_{3}\right)$.

TABELA B6: Valores de ácidos voláteis totais (AVT) no período chuvoso (valores em $\mathrm{mg} / \mathrm{LCaCO}_{3}$ ).

TABELA B7: Valores de DQO no período seco (valores em mg/L). 
TABELA B8: Valores de DQO no período chuvoso (valores em mg/L)................ 118

TABELA B9: Valores de NTK no período seco (valores em mg/L)......................... 119

TABELA B10: Valores de N amoniacal no período seco (valores em mg/L)......... 119

TABELA B11: Valores de sólidos totais no período seco (valores em mg/L)......... 120

TABELA B12: Valores de sólidos totais no período chuvoso (valores em mg/L).... 120

TABELA B13: Valores de sólidos totais fixos no período seco (valores em mg/L). 121

TABELA B14: Valores de sólidos totais fixos no período chuvoso (valores em

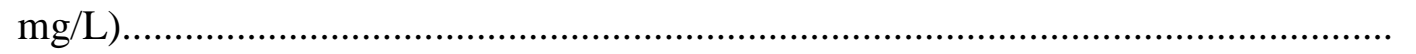

TABELA B15: Valores de sólidos totais voláteis no período seco (valores em $\mathrm{mg} / \mathrm{L})$

TABELA B16: Valores de sólidos totais voláteis no período chuvoso (valores em $\mathrm{mg} / \mathrm{L})$.

TABELA B17: Valores de sólidos suspensos totais no período seco (valores em $\mathrm{mg} / \mathrm{L})$

TABELA B18: Valores de sólidos suspensos totais no período chuvoso (valores em $\mathrm{mg} / \mathrm{L})$

TABELA B19: Valores de sólidos suspensos fixos no período seco (valores em $\mathrm{mg} / \mathrm{L})$.

TABELA B20: Valores de sólidos suspensos fixos no período chuvoso (valores $\mathrm{em} \mathrm{mg} / \mathrm{L})$

TABELA B21: Valores de sólidos suspensos voláteis no período seco (valores em $\mathrm{mg} / \mathrm{L})$

TABELA B22: Valores de sólidos suspensos voláteis no período chuvoso (valores $\mathrm{em} \mathrm{mg} / \mathrm{L})$ 


\section{LISTA DE QUADROS}

QUADRO 3.2.3.1: Critérios para seleção de área de aterro sanitário

QUADRO 3.2.4.1: Probabilidade de ocorrência de acidentes decorrentes de um aterro de resíduos - Riscos Ambientais.

QUADRO 3.2.4.2: Probabilidade de ocorrência de acidentes decorrentes de um aterro de resíduos - Riscos à Saúde Humana............................................................... 28

QUADRO 4.3.1: Dias de coleta e pontos amostrados.............................................. 61 
LISTA DE ABREVIATURAS E SIGLAS

ABNT

AVT

DBO

DQO

EIA

IPT

MOD

$\mathrm{N}$-amoniacal

NBR

ND

NEPER

N-orgânico

NTK

$\mathrm{P}$

P-total

PEAD

PMSC

PVC

RIMA

RSD

RSS

SAAE

SNIS

SSF

SST

SSV

ST

STF

STV

TAC
Associação Brasileira de Normas Técnicas

Ácidos Voláteis Totais

Demanda Bioquímica de Oxigênio

Demanda Química de Oxigênio

Estudo de Impacto Ambiental

Instituto de Pesquisas Tecnológicas

Matéria Orgânica Dissolvida

Nitrogênio Amoniacal

Norma Brasileira Registrada

Não Detectado

Núcleo de Estudo e Pesquisa em Resíduos Sólidos

Nitrogênio Orgânico

Nitrogênio Total Kjeldahl

Precipitação

Fósforo Total

Polietileno de Alta Densidade

Prefeitura Municipal de São Carlos

Policloreto de Vinila

Relatório de Impacto Ambiental

Resíduos Sólidos Domiciliares

Resíduos de Serviços de Saúde

Serviço Autônomo de Água e Esgoto

Sistema Nacional de Informação sobre Saneamento

Sólidos Suspensos Fixos

Sólidos Suspensos Totais

Sólidos Suspensos Voláteis

Sólidos Totais

Sólidos Totais Fixos

Sólidos Totais Voláteis

Termo de Ajustamento de Conduta 


\section{LISTA DE SÍMBOLOS}

As

B

$\mathrm{Ba}$

$\mathrm{Ca}$

$\mathrm{CaCO}_{3}$

$\mathrm{Cd}$

$\mathrm{CH}_{4}$

$\mathrm{Cl}$

$\mathrm{CN}$

Co

$\mathrm{CO}_{2}$

$\mathrm{CO}_{3}{ }^{2-}$

$\mathrm{Cr}$

$\mathrm{Cu}$

$\mathrm{Fe}$

$\mathrm{H}_{2}$

$\mathrm{HCl}$

$\mathrm{HCO}^{3-}$

$\mathrm{H}_{2} \mathrm{CO}_{3}$

$\mathrm{Hg}$

$\mathrm{H}_{2} \mathrm{~S}$

K

$\mathrm{Li}$

$\mathrm{Mg}$

Mn

$\mathrm{Na}$

$\mathrm{Ni}$

$\mathrm{N}_{2}$

$\mathrm{NH}_{3}$

$\mathrm{NH}_{4}$

$\mathrm{NO}_{3}$
Arsênio

Boro

Bário

Cálcio

Carbonato de Cálcio

Cádmio

Metano

Cloro

Cianeto

Cobalto

Dióxido de Carbono

Carbonato

Cromo

Cobre

Ferro

Gás Hidrogênio

Ácido Clorídrico

Bicarbonato

Ácido Carbônico

Mercúrio

Gás Sulfídrico

Potássio

Lítio

Magnésio

Manganês

Sódio

Níquel

Gás Nitrogênio

Amônia

Amônio

Nitrato 


$\begin{array}{ll}\mathrm{NO}_{2} & \text { Nitrito } \\ \mathrm{O}_{2} & \text { Gás Oxigênio } \\ \mathrm{OH}^{-} & \text {Hidróxido } \\ \mathrm{P} & \text { Fósforo } \\ \mathrm{Pb} & \text { Chumbo } \\ \mathrm{pH} & \text { Potencial Hidrogeniônico } \\ \mathrm{Q} & \text { Vazão } \\ \mathrm{Se} & \text { Selênio } \\ \mathrm{Zn} & \text { Zinco }\end{array}$




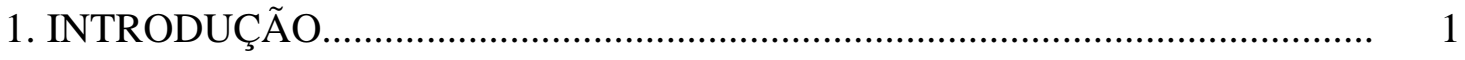

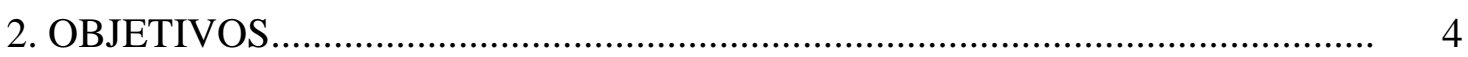

2.1 OBJETIVO PRINCIPAL .............................................................................

2.2 OBJETIVOS ESPECÍFICOS............................................................................ 4

3. REVISÃO BIBLIOGRÁFICA......................................................................... 5

3.1 CONCEITOS SOBRE RESÍDUOS SÓLIDOS................................................... 5

3.1.1 DEFINIÇÃO, CLASSIFICAÇÃO E CARACTERIZAÇÃO............................. 5

3.1.2 SITUAÇÃO DOS RESIIDUOS SÓLIDOS URBANOS NO BRASIL............... 8

3.2 ATERROS SANITÁRIOS............................................................................. 12

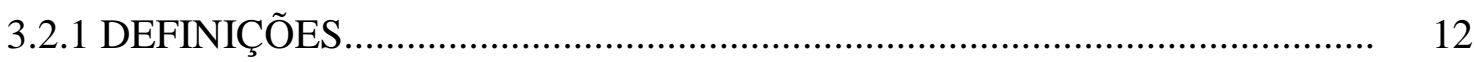

3.2.2 FASES DA DECOMPOSIÇÃO DA MATÉRIA ORGÂNICA NO ATERRO SANITÁRIO...................................................................................... 15

3.2.2.1 FATORES QUE INFLUENCIAM A DIGESTÃO DA MATÉRIA ORGÂNICA EM ATERROS SANITÁRIOS......................................................... 18

3.2.3 CRITÉRIOS PARA SELEÇÃO DE ÁREAS PARA ATERROS SANITÁRIOS......................................................................................... 21

3.2.4 IMPACTOS AMBIENTAIS DEVIDO A ATERROS SANITÁRIOS.............. 25

3.3 LIXIVIADOS OU LÍQUIDOS PERCOLADOS.................................................. 30

3.3.1 DEFINIÇÃO .............................................................................................. 30

3.3.2 CARACTERÍSTICAS E COMPOSIÇÃO....................................................... 30

3.3.2.1 BIODEGRADABILIDADE DO LIXIVIADO............................................ 43

3.3.3 TAXA DE GERAÇÃO DE LIXIVIADO E FATORES INFLUENTES......... 46

3.3.3.1 DINÂMICA DA ÁGUA NO ATERRO SANITÁRIO.................................... 46

3.3.3.2 TAXA DE GERAÇÃO.............................................................................. 48

3.3.4 CONTAMINANTES DO LIXIVIADO...................................................... 50

4. MATERIAL E MÉTODOS.......................................................................... 54

4.1 CARACTERIZAÇÃO DO ATERRO SANITÁRIO DE SÃO CARLOS........... 54

4.2 COLETA DAS AMOSTRAS.................................................................... 57

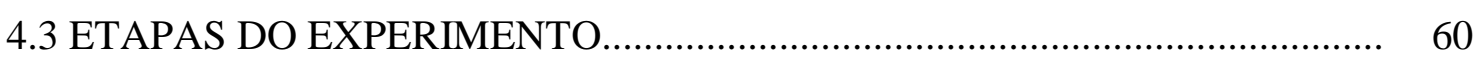

4.4 ANÁLISES FÍSICO-QUÍMICAS REALIZADAS............................................ 61 
4.5 OBTENÇÃO DE INFORMAÇÕES SOBRE O ATERRO SANITÁRIO E 62 DADOS PLUVIOMÉTRICOS.

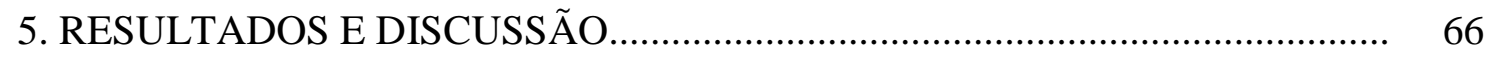

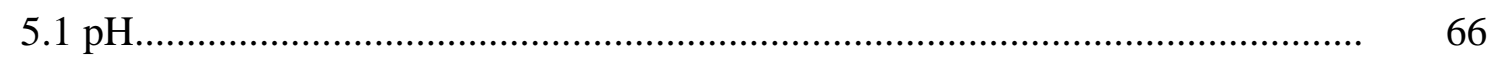

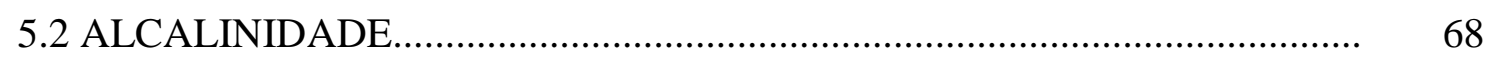

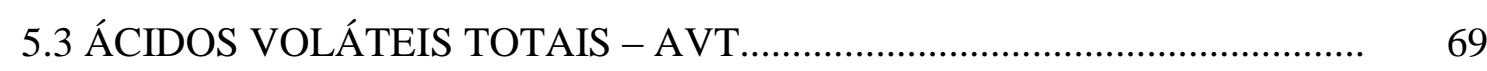

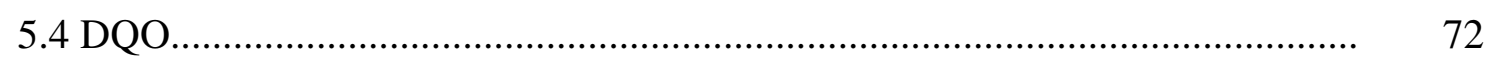

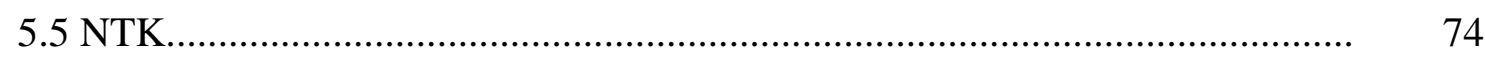

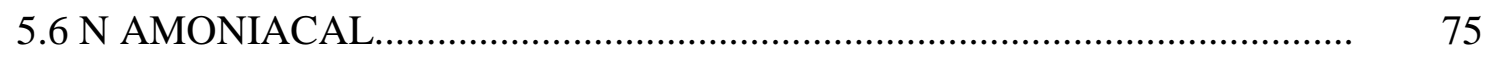

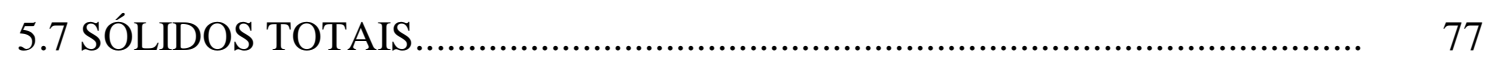

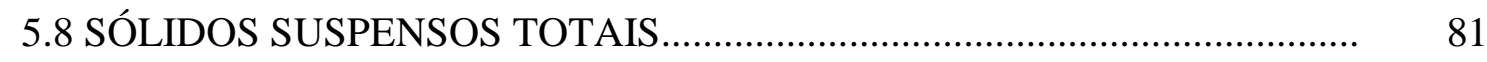

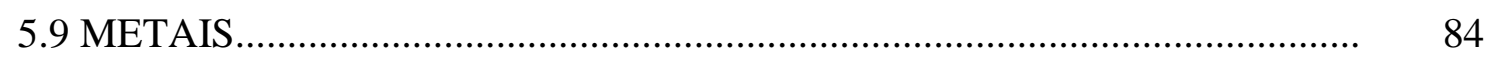

5.10 BIODEGRADABILIDADE DO LIXIVIADO............................................. 93

5.11 CONSIDERAÇÕES SOBRE OS RESULTADOS OBTIDOS........................ 96

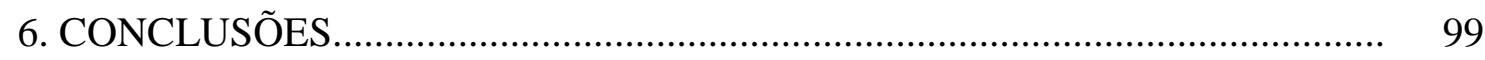

7. RECOMENDAÇÕES PARA TRABALHOS FUTUROS.................................. 100

8. REFERÊNCIAS BIBLIOGRÁFICAS............................................................. 101

ANEXO A - ANÁLISES FÍSICO - QUÍMICAS DAS AMOSTRAS.................... 106

ANEXO B - RESULTADOS DAS ANÁLISES.................................................. 115

ANEXO C - RESULTADOS DOS METAIS..................................................... 126 


\section{INTRODUÇÃO}

A disposição de resíduos sólidos é tema atual e relevante frente à crescente conscientização ambiental da população e os avanços da legislação. Por muitos anos os resíduos foram destinados sem que houvesse a preocupação de evitar a poluição do solo, da água e do ar.

O aterro sanitário é a única técnica de disposição final de resíduos. Quando bem construído e operado o aterro evita a contaminação do solo e os líquidos gerados no processo de decomposição são coletados e podem receber tratamento adequado. A inadequada disposição dos lixiviados dos aterros sanitários pode causar sérios problemas ao meio ambiente, especialmente aos corpos d’água.

As características dos lixiviados variam em função da localidade, da estação do ano e ao longo da vida útil de um aterro. Mudanças são observadas na vazão gerada, na concentração e composição química do lixiviado. Fatos assim tornam o lixiviado um efluente peculiar e impossibilitam o emprego de parâmetros pré-determinados em projetos semelhantes de tratamento. Um sistema de tratamento de lixiviados deve contemplar estes fatos e mostrar grande flexibilidade na operação, permitindo lidar com tais variações.

Quanto à idade do lixiviado, tem-se a diferenciação entre lixiviado "velho" e lixiviado "novo". Nos lixiviados considerados "velhos", a concentração de matéria orgânica é menor, pois esta já se encontra em fase adiantada de decomposição anaeróbia - fase metanogênica. No lixiviado "novo", a concentração de matéria orgânica é maior e 
são observados altos valores de poluentes orgânicos. Estes lixiviados encontram-se ainda na fase ácida da decomposição e pH baixos são característicos neste caso.

A biodegradabilidade do lixiviado pode ser avaliada por meio das relações DBO/DQO, STV/ST e AVT/DQO. Em especial a última relação oferece uma boa indicação quanto à idade do lixiviado já que lixiviados "novos" apresentam maiores relações AVT/DQO devido à grande presença de ácidos. As relações DBO/DQO e STV/ST também apresentam maiores valores para lixiviados "novos", sugerindo a presença de matéria orgânica biodegradável.

As elevadas concentrações de amônia e alcalinidade encontradas em alguns lixiviados são provavelmente, responsáveis pela toxicidade observada neste efluente.

A pesquisa aqui proposta pretende investigar e determinar as fases de decomposição dos lixiviados das diversas frações do aterro sanitário de São Carlos SP. Para isso, procedeu-se a caracterização física e química dos lixiviados, e de posse dos resultados e com base em faixa de valores sugeridos pela literatura, definiu-se em qual fase da decomposição o lixiviado se encontra. A investigação da biodegradabilidade do lixiviado através da relação AVT/DQO também foi contemplada nesta pesquisa, pois vem proporcionar mais um subsídio na determinação da fase de decomposição do lixiviado.

Com a finalidade de complementar este estudo do lixiviado do aterro de São Carlos foram reunidos dados de precipitação pluviométrica. Estes dados são importantes à medida que a precipitação está intimamente ligada à concentração de poluentes no lixiviado. A precipitação pluviométrica atinge o aterro e pode influenciar na diluição dos poluentes nas lagoas de acumulação de lixiviado. Sendo assim, uma investigação do efeito da diluição pela precipitação nas lagoas pode indicar se as lagoas 
oferecem algum tipo de tratamento ao lixiviado ou somente servem para diluir os poluentes.

Por fim, este trabalho procurou contribuir para o desenvolvimento dos estudos sobre lixiviados de aterros sanitários. Ele vem dar continuidade à linha de pesquisa "Estudo de alternativas para tratamento de chorume" locada no Núcleo de Estudo e Pesquisa em Resíduos Sólidos - NEPER, grupo de pesquisa vinculado ao CNPq, existente no Departamento de Hidráulica e Saneamento da Escola de Engenharia de São Carlos. 
2. OBJETIVOS

\subsection{OBJETIVO PRINCIPAL}

Determinar as fases de decomposição dos resíduos do aterro sanitário de São Carlos com base nas características dos lixiviados gerados.

\subsection{OBJETIVOS ESPECÍFICOS}

Avaliar as características físico-químicas do lixiviado e sua correlação com as fases de decomposição dos resíduos do aterro sanitário de São Carlos.

Avaliar a variação das concentrações dos parâmetros analisados em períodos distintos com diferentes precipitações.

- Investigar a biodegradabilidade do lixiviado através das relações AVT/DQO e STV/ST. 


\section{REVISÃO BIBLIOGRÁFICA}

\subsection{CONCEITOS SOBRE RESÍDUOS SÓLIDOS}

\subsubsection{DEFINIÇÃO, CLASSIFICAÇÃO E CARACTERIZAÇÃO}

Segundo a NBR 10004/04 resíduos sólidos são resíduos nos estados sólido e semi-sólido, que resultam de atividades de origem industrial, doméstica, hospitalar, comercial, agrícola, de serviços e de varrição. Ficam incluídos nesta definição os lodos provenientes de sistemas de tratamento de água, aqueles gerados em equipamentos e instalações de controle de poluição, bem como determinados líquidos cujas particularidades tornem inviável o seu lançamento em rede pública de esgotos ou corpos de água, ou exijam para isso soluções técnicas e economicamente inviáveis em face à melhor tecnologia disponível.

A NBR 8419/92 define resíduos sólidos urbanos como os resíduos sólidos gerados num aglomerado urbano, excetuados os resíduos industriais perigosos, hospitalares sépticos e de aeroportos e portos.

A classificação dos resíduos envolve a identificação do processo ou atividade que deu origem ao resíduo e seus constituintes, suas características e a comparação destes constituintes com listagens de resíduos e substâncias cujo impacto à saúde e ao meio ambiente é conhecido (ABNT, NBR 10004/04).

Os resíduos são classificados em:

a) Resíduos Classe I - Perigosos

b) Resíduos Classe II - Não Perigosos

- Resíduos Classe II A - Não Inertes

- Resíduos Classe II B - Inertes 
Os resíduos perigosos oferecem risco à saúde pública, podendo apresentar características como inflamabilidade, corrosividade, reatividade, toxicidade ou patogenicidade.

Os resíduos não perigosos e não inertes (Classe II A) podem apresentar características como biodegrabilidade, combustibilidade ou solubilidade em água e não se enquadram na Classe I ou Classe II B. Como exemplo deste tipo de resíduo tem-se os resíduos sólidos domiciliares.

Por fim, os resíduos não perigosos e inertes (Classe II B), quando submetidos a ensaios com água destilada não têm nenhum de seus constituintes solubilizados a concentrações superiores aos padrões de potabilidade de água, exceto cor, turbidez, dureza e sabor. O exemplo mais conhecido deste tipo de resíduo é o dos resíduos de construção e demolição.

A composição dos resíduos sólidos domiciliares varia muito, principalmente em função dos hábitos culturais, sociais e da situação econômica do aglomerado populacional. Em estudos que envolvem resíduos sólidos e suas formas de tratamento e disposição final, torna-se imprescindível sua caracterização. GOMES (1989) e FRÉSCA (2007) procederam à caracterização dos resíduos domiciliares na cidade de São Carlos SP, que se encontra na Tabela 3.1.1.1. 
TABELA 3.1.1.1: Composição física dos resíduos sólidos da cidade de São Carlos - SP

\begin{tabular}{|c|c|c|}
\hline \multirow{2}{*}{ Componente } & \multicolumn{2}{|c|}{ Porcentagem média em massa (base úmida) } \\
\hline & Gomes (1989)* & Frésca (2007) \\
\hline Matéria orgânica putrescível & 56,7 & 59,08 \\
\hline Papel e papelão & 21,3 & 6,44 \\
\hline Plástico & 8,5 & 10,47 \\
\hline Metal & 5,4 & 1,31 \\
\hline Trapos & 3,4 & - \\
\hline Madeira, couro, borracha & 2,3 & - \\
\hline Vidro & 1,4 & 1,67 \\
\hline Embalagem longa vida & - & 0,94 \\
\hline Inertes & 1,3 & - \\
\hline Rejeitos/outros & - & 20,09 \\
\hline TOTAL & 100 & $\overline{100}$ \\
\hline
\end{tabular}

* Peso específico $\approx 136,40 \mathrm{~kg} / \mathrm{m}^{3}$ e Teor de umidade médio $=46,4 \%$

Em relação aos dados apresentados por FRÉSCA (2007) a Prefeitura Municipal de São Carlos - PMSC (2007) infere que:

Cerca de $80 \%$ dos resíduos sólidos encaminhados para o aterro sanitário de São Carlos são passíveis de reaproveitamento, seja via reciclagem (20\%) ou compostagem $(60 \%)$;

A grande porcentagem de rejeito presente na composição gravimétrica deve-se, principalmente, pela presença de fraldas, borrachas, madeira, panos e tecidos;

O plástico mole é constituído, em sua maioria, pelas "sacolas de supermercado" que são utilizadas para armazenar os resíduos e, posteriormente, são dispostas para a coleta;

Com relação ao alumínio e outros metais observa-se uma baixa representatividade na quantidade global, devido principalmente ao mercado 
existente para este tipo de resíduo. Desta forma, este resíduo é desviado do aterro sanitário tanto pela coleta seletiva existente no município quanto pela ação dos catadores autônomos.

\subsubsection{SITUAÇÃO DOS RESÍDUOS SÓLIDOS URBANOS NO BRASIL}

Em 2006 foi publicado pela Secretaria Nacional de Saneamento Ambiental do Ministério das Cidades o Diagnóstico do Manejo de Resíduos Sólidos Urbanos. O órgão responsável pela pesquisa foi o Sistema Nacional de Informação sobre Saneamento (SNIS). O Diagnóstico retrata as características e a situação da prestação dos serviços de limpeza urbana e manejo de resíduos sólidos em 247 municípios, de todos os estados brasileiros e mais o Distrito Federal.

De acordo com este estudo, o destino final dos resíduos coletados, totalizando 11,7 milhões de toneladas, está assim distribuído conforme Figura 3.1.2.1:

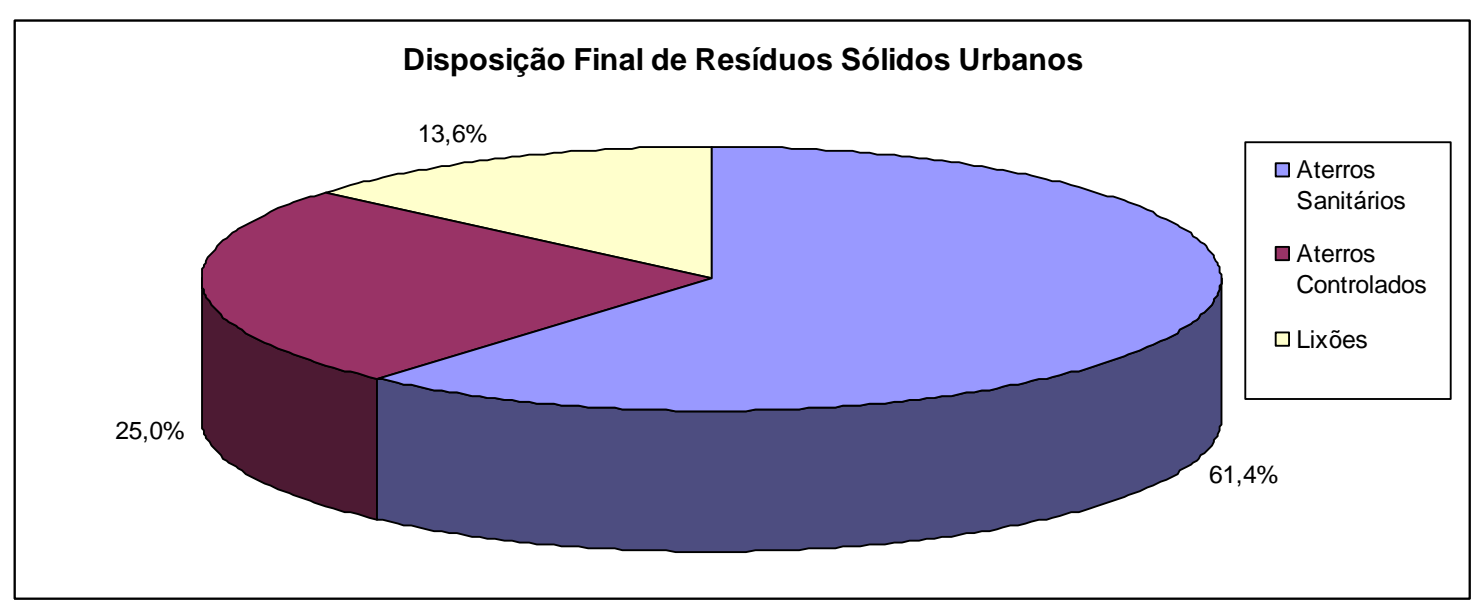

FIGURA 3.1.2.1: Distribuição da disposição final dos resíduos sólidos urbanos

Fonte: SNIS, (2006)

O estudo aponta ainda que, há coleta seletiva em 55,9\% dos municípios presentes na amostra, em geral sob a forma de coleta porta-a-porta. Já a coleta seletiva 
não formal - realizada por catadores - está presente em $83 \%$ dos municípios. Os catadores estão organizados em associações e cooperativas em 53\% das cidades pesquisadas. A quantidade média de materiais recicláveis recuperados é de $2,8 \mathrm{~kg}$ por habitante a cada ano, sendo 44,3\% papel ou papelão, 27,6\% plásticos e 15,3\% metais. Vidros representam $9,8 \%$ e outros totalizam $2,9 \%$.

Com relação ao desempenho financeiro, $40,1 \%$ dos municípios não cobram pelos serviços de limpeza urbana, sendo que naqueles que cobram e que informaram, o valor da receita arrecadada municipal pelos serviços de limpeza urbana, o valor médio verificado é de $\mathrm{R} \$ 31,00 /$ habitante/ano. Mesmo tendo avançado significativamente, ao se comparar com os dados do "Diagnóstico do Manejo de Resíduos Sólidos Urbanos de 2002", é possível perceber, na nova edição, que ainda há muito a ser feito para se chegar aos padrões realmente ideais (SNIS, 2006).

Assim sendo, os conceitos de gestão e gerenciamento são importantes para o entendimento e resolução da problemática dos resíduos. O conceito de gestão de resíduos sólidos abrange atividades referentes à tomada de decisões estratégicas e à organização do setor para esse fim, envolvendo instituições, políticas, instrumentos e meios (LEITE, 1997). Gerenciamento de resíduos sólidos pode ser definido como o controle da geração, estocagem, coleta, transferência, transporte, processamento e disposição dos resíduos sólidos, de acordo com princípios de saúde pública, econômicos, de engenharia, de conservação, estéticos, e de proteção ao meio ambiente, sendo também responsável pelas atitudes públicas (TCHOBANOGLOUS, THEISEN \& VIGIL, 1993).

Segundo LEITE (1997), modelo de gestão de resíduos sólidos é um “conjunto de referências político-estratégicas, institucionais, legais e financeiras capaz de orientar a 
organização do setor". Os elementos indispensáveis na composição de um modelo de gestão são:

Reconhecimento dos diversos agentes sociais envolvidos, identificando os papéis por eles desempenhados e promovendo a sua articulação;

Consolidação da base legal necessária e dos mecanismos que viabilizem a implementação das leis;

$>$ Mecanismos de financiamento para a auto-sustentabilidade das estruturas de gestão e do gerenciamento;

Informação à sociedade, empreendida tanto pelo poder público, quanto pelos setores produtivos envolvidos, para que haja um controle social;

Sistema de planejamento integrado orientando a implementação das políticas públicas para o setor.

A composição de modelos de gestão envolve, portanto, fundamentalmente três aspectos, que devem ser articulados: arranjos institucionais, instrumentos legais e mecanismos de financiamento.

Uma vez definido o modelo básico de gestão deve-se criar uma estrutura para o gerenciamento que se adéque ao modelo. Dessa forma, o gerenciamento de resíduos exige o emprego das melhores técnicas na busca do enfrentamento da questão. A solução do problema dos resíduos pode envolver uma complexa relação interdisciplinar, abrangendo os aspectos políticos e geográficos, o planejamento local e regional, elemento de sociologia e demografia, entre outros (CASTRO, 2001).

Gerenciar os resíduos de forma integrada é articular ações normativas, operacionais, financeiras e de planejamento que uma administração municipal desenvolve, apoiada em critérios sanitários, ambientais e econômicos, para coletar, tratar e dispor o lixo de uma cidade, ou seja, é acompanhar de forma criteriosa todo 
ciclo dos resíduos, da geração à disposição final, empregando as técnicas e tecnologias mais compatíveis com a realidade local (LEITE, 1997).

Em São Carlos, a gestão e o gerenciamento dos resíduos sólidos urbanos estão sob responsabilidade da Prefeitura Municipal de São Carlos - PMSC, especificamente a cargo do Departamento de Política Ambiental, vinculado à Secretaria Municipal de Desenvolvimento Sustentável, Ciência e Tecnologia. Desde 2001 existe uma divisão dedicada especialmente à gestão de resíduos sólidos da cidade, conforme ilustra a Figura 3.1.2.2.

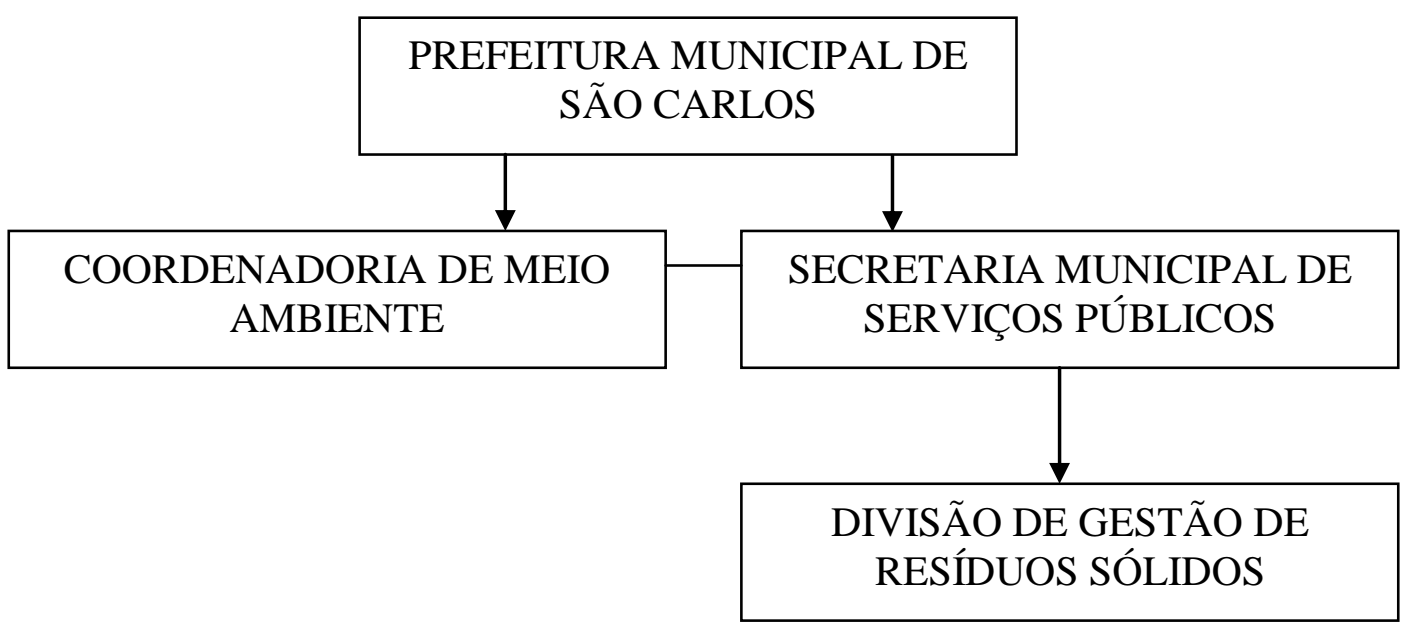

FIGURA 3.1.2.2: Posição da Divisão de Gestão de Resíduos Sólidos no organograma da Prefeitura

Fonte: PMSC (2010)

Embora a gestão dos resíduos sólidos urbanos seja de responsabilidade da Coordenadoria de Meio Ambiente e da Secretaria Municipal de Serviços Públicos, a operacionalização dos serviços de coleta, transporte, tratamento e destinação final dos Resíduos Sólidos Domiciliares (RSD) e Resíduos de Serviços de Saúde (RSS) são terceirizadas. 


\subsection{ATERROS SANITÁRIOS}

\subsubsection{DEFINIÇÕES}

Os resíduos sólidos são gerados continuamente e sua disposição de forma adequada torna-se necessária. Historicamente, os aterros têm sido o método mais aceito de disposição de resíduos sólidos, em termos econômicos e ambientais (TCHOBANOGLOUS, THEISEN \& VIGIL, 1993). O aterro sanitário é uma forma de disposição final de resíduos sólidos urbanos no solo, dentro de critérios de engenharia e normas operacionais específicas, proporcionando o confinamento seguro dos resíduos evitando danos ou riscos à saúde pública e minimizando os impactos ambientais. Esses critérios de engenharia mencionados materializam-se no projeto de sistemas de drenagem periférica e superficial para afastamento de águas de chuva, de drenagem de fundo para coleta do lixiviado, do sistema de tratamento para o lixiviado drenado, de drenagem e queima dos gases gerados durante o processo de bioestabilização da matéria orgânica (BIDONE \& POVINELLI, 1999).

A Figura 3.2.1.1 ilustra os principais componentes de um aterro sanitário.

Os principais gases gerados nos aterros sanitários são o $\mathrm{CH}_{4}, \mathrm{CO}_{2}, \mathrm{~N}_{2}, \mathrm{H}_{2}$ e $\mathrm{H}_{2} \mathrm{~S}$. Maiores cuidados deverão ser dispensados ao metano, que pode representar até $60 \%$ do gás gerado em aterros. De acordo com LEITE (1991), o controle da geração e migração desses gases é realizado através de um adequado sistema de drenagem, constituído por drenos verticais colocados em diferentes pontos do aterro. Estes drenos são construídos com a superposição de tubos perfurados de concreto ou de PVC revestidos de brita, que atravessam no sentido vertical o aterro, desde o solo até a camada superior, como se fossem chaminés, interligadas em suas bases com os drenos de lixiviados. 


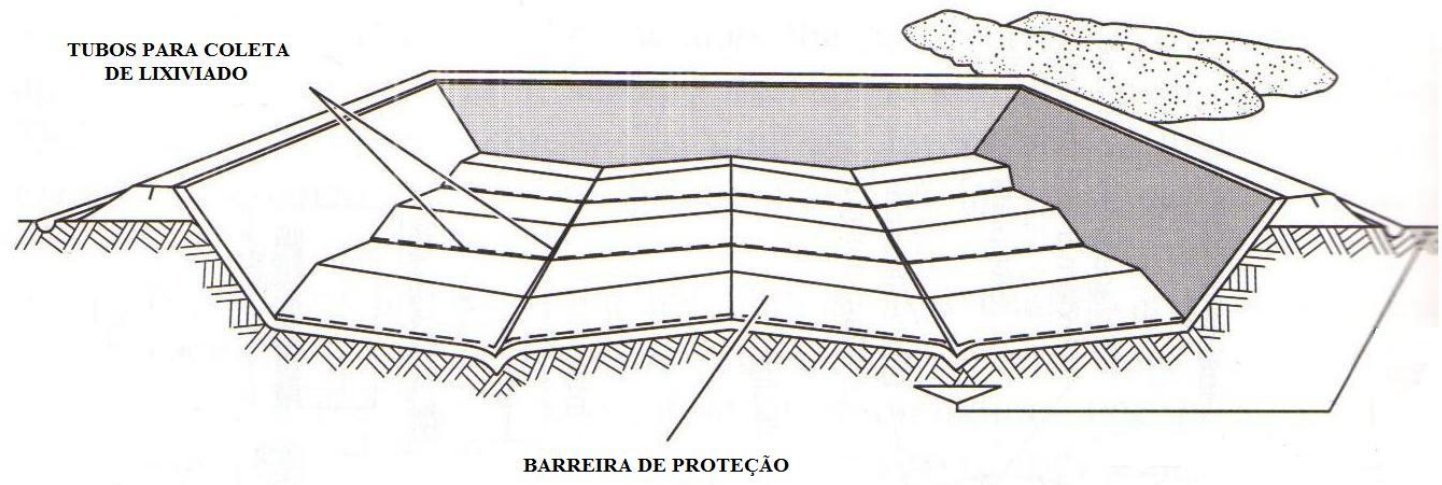

(a)

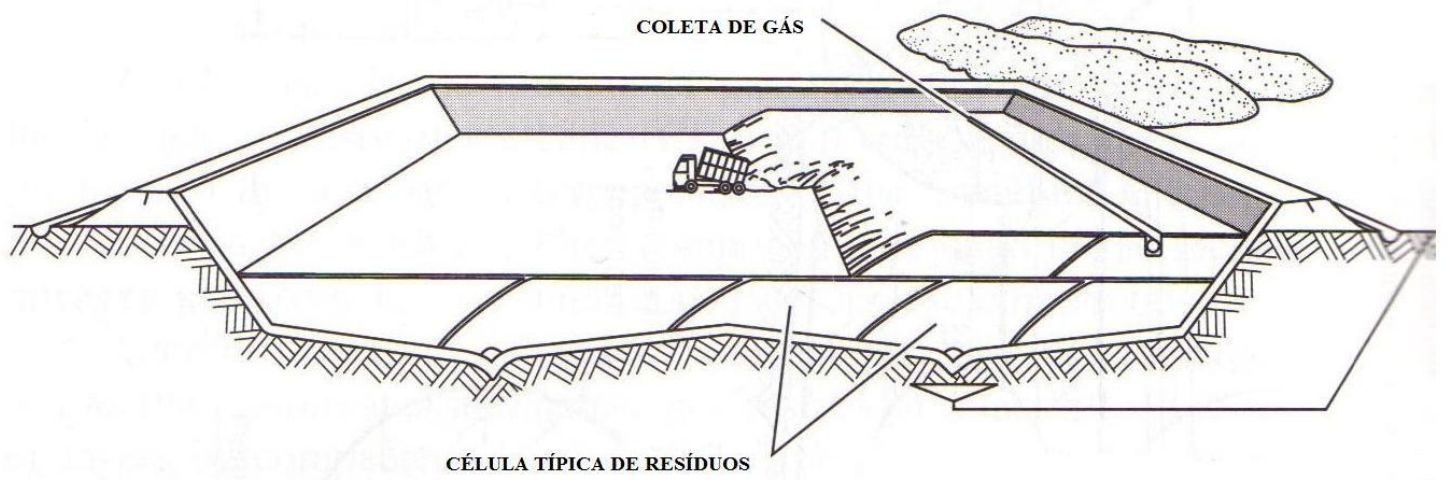

(b)

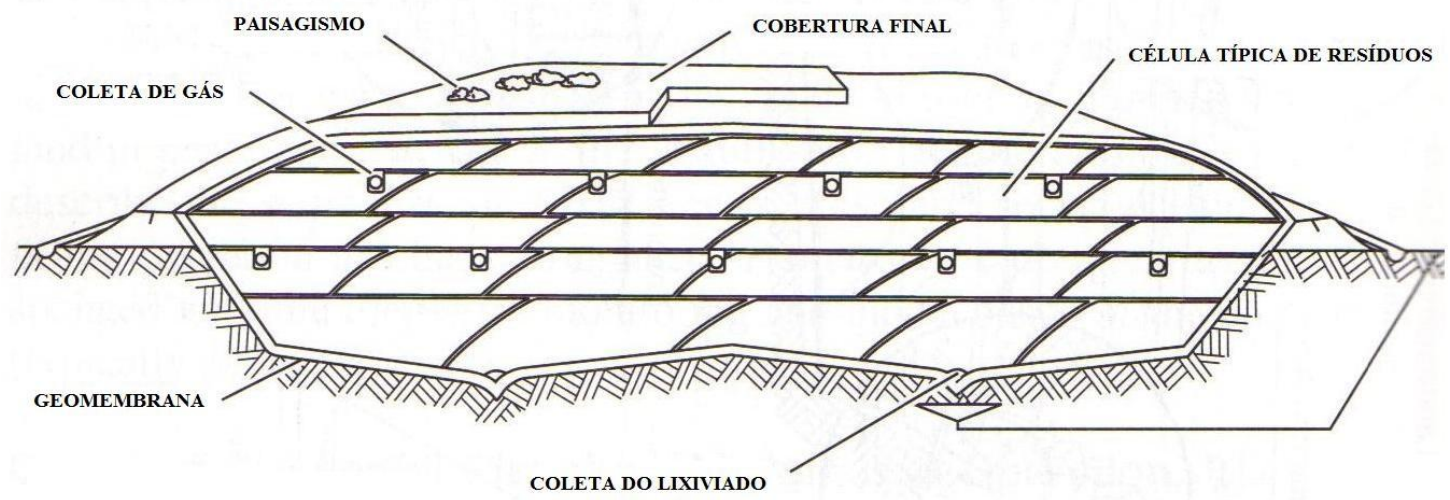

(c)

FIGURA 3.2.1.1: Desenvolvimento de um aterro sanitário (a) escavação e instalação do liner, (b) disposição dos resíduos no aterro, e (c) encerramento do aterro Fonte: TCHOBANOGLOUS, THEISEN \& VIGIL (1993) 
A Figura 3.2.1.2 mostra o detalhe do coletor de gases do aterro sanitário de São Carlos. Este estava sendo construído com tela de arame e preenchido com brita.

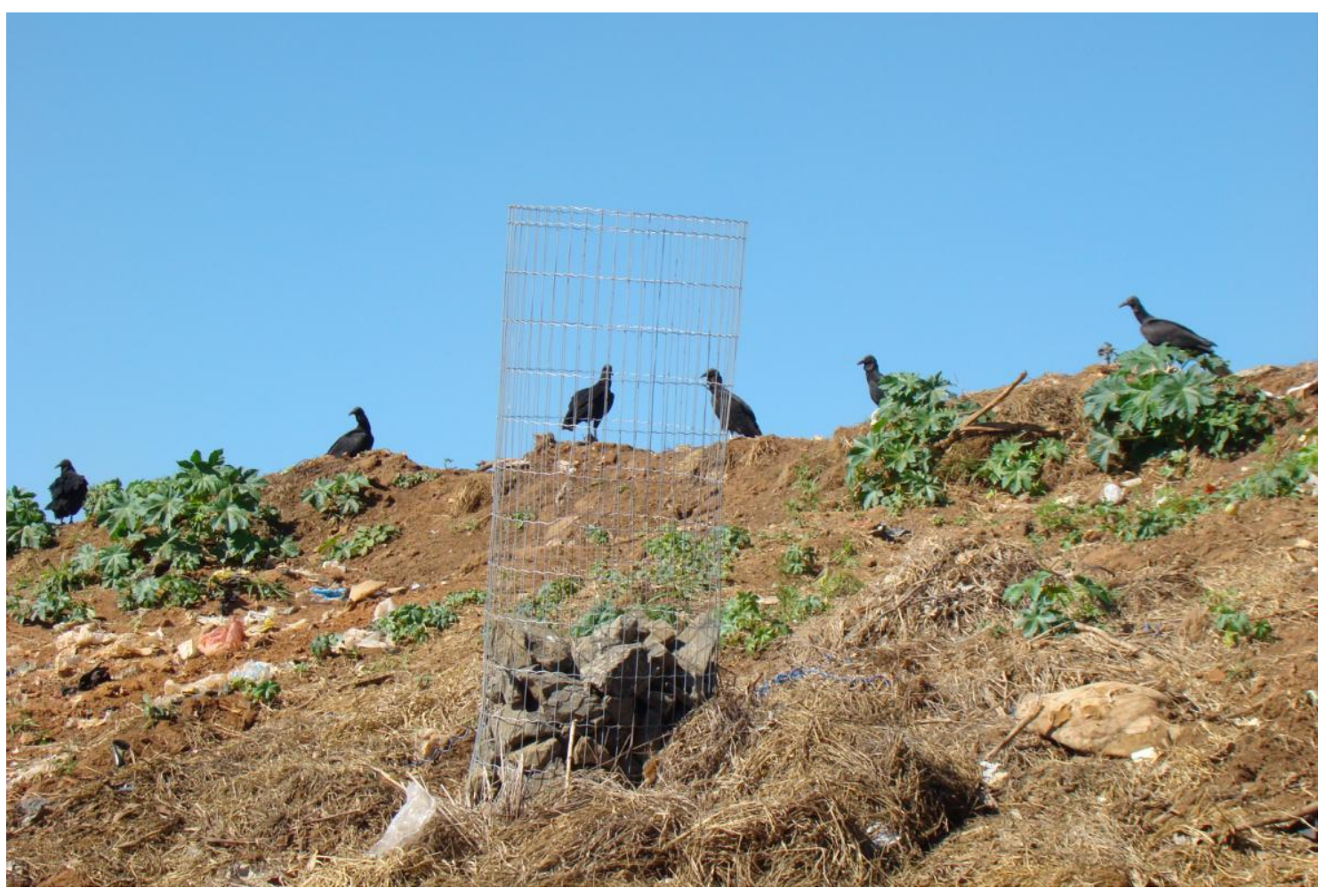

FIGURA 3.2.1.2: Detalhe do coletor de gases

São necessários para aterros dois sistemas de drenagem: superficial e subsuperficial.

LEITE (1991) explica que o sistema de drenagem superficial e do entorno tem como finalidade básica desviar as águas da bacia de contribuição para fora da área do aterro, diminuindo dessa forma o volume de lixiviado, durante e após a fase de execução do aterro, além de possibilitar a sua operação inclusive em dias de chuva. Este sistema requer a construção de canais de superfície livre a meia encosta, ou canaletas envolvendo toda a área do aterro. Toda água recolhida por esse sistema deverá ser conduzida para um ponto distante, onde não cause danos ao aterro, durante e após a fase de operação. 
Já o sistema de drenagem sub-superficial visa coletar e conduzir o lixiviado para uma unidade de tratamento, evitando o comprometimento do lençol freático. É constituído basicamente de estruturas drenantes com escoamento em meio poroso (LEITE, 1991).

\subsubsection{FASES DA DECOMPOSIÇÃO DA MATÉRIA ORGÂNICA NO ATERRO}

\section{SANITÁRIO}

FARQUHAR \& ROVERS (1973) apresentaram uma evolução temporal da transformação anaeróbia em um aterro sanitário. Este modelo foi aperfeiçoado por REES (1980) e POHLAND \& GOULD (1986).

De acordo com POHLAND \& GOULD (1986), a transformação da matéria orgânica em um aterro é um processo de cinco fases:

Fase 1 - ajustamento inicial ou aeróbia: disposição dos resíduos, acúmulo de umidade, subsidência inicial e cobertura da área. Essa umidade acumulada auxilia a realização das reações que intervém na produção de gás e líquidos percolados. Segundo BIDONE (2008), nessa fase as bactérias aeróbias iniciam a estabilização da matéria orgânica, com consequente e predominante geração de $\mathrm{CO}_{2}$. A atividade metabólica desses microrganismos é exotérmica, o que justifica a elevação de temperatura verificada no âmbito da massa sólida neste estágio;

Fase 2 - transição: formação do lixiviado e transição da fase aeróbia para a anaeróbia ou anóxica. Estabelecimento das condições de óxido-redução. Aparecimento de compostos intermediários (ácidos voláteis);

Fase 3 - formação de ácidos: predominância de ácidos orgânicos voláteis de cadeia longa (propiônico, butírico). Oxidação dos ácidos voláteis e dos ácidos graxos de cadeia longa para ácido acético e hidrogênio, precursores diretos do 
metano. Decréscimo do $\mathrm{pH}$ com consequente mobilização e possível complexação de compostos metálicos. Aumento da concentração da DQO do lixiviado. Liberação de nutrientes com N e P que serão utilizados como nutriente para o crescimento da biomassa;

Fase 4 - fermentação metanogênica: produtos intermediários que aparecem durante a fase de formação de ácidos são convertidos em $\mathrm{CH}_{4} \mathrm{e} \mathrm{CO}_{2}$. Retorno do pH à condição de tampão, controlado pelos ácidos voláteis. Potencias redox nos valores mais baixos. Precipitação e complexação de metais. Redução na intensidade de formação de lixiviado. Drástica redução de DQO (medida no lixiviado) com correspondente aumento na produção de gás;

Fase 5 - maturação final: estabilização da atividade biológica, com relativa inatividade. Escassez de nutrientes e paralisação da produção de gás. Predominância de condições ambientais naturais. Aumento do valor do potencial redox com aparecimento de $\mathrm{O}_{2}$ e espécies oxidadas. Conversão lenta dos materiais orgânicos resistentes aos microrganismos em substâncias húmicas complexadas com metais.

A Figura 3.2.2.1 representa estas fases. 


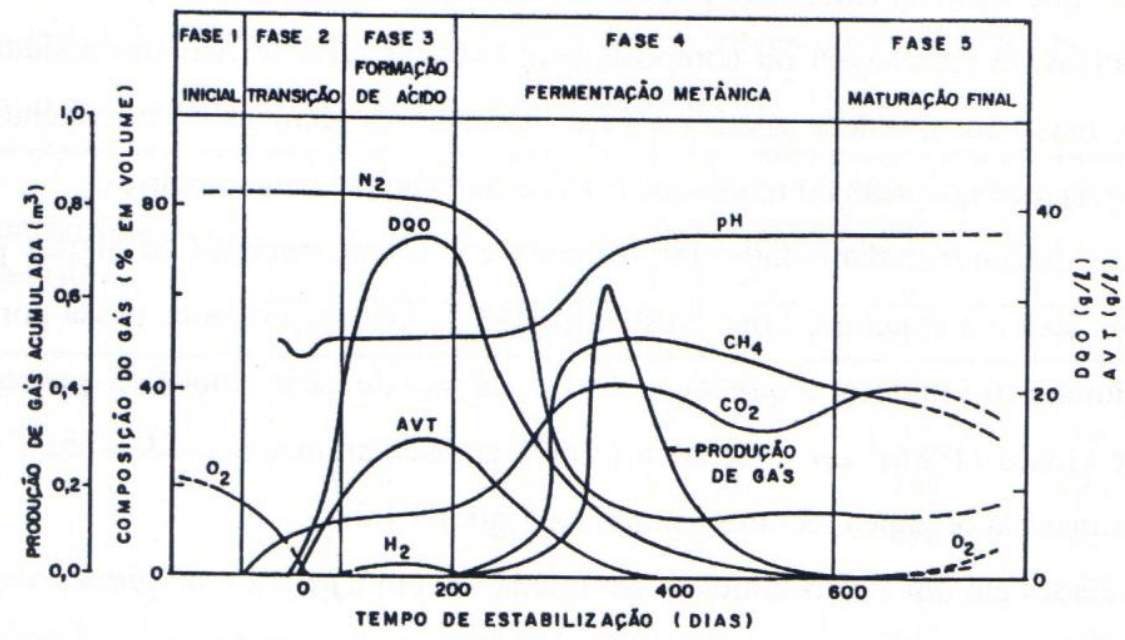

FIGURA 3.2.2.1: Variações de parâmetros selecionados, indicadores das fases de estabilização da matéria orgânica em um aterro sanitário Fonte: POHLAND \& GOULD (1986)

Pode-se observar na Figura acima que a curva de DQO dos lixiviados sugere uma influência marcante de degradação da matéria orgânica na transformação dos substratos, enfatizando o papel fundamental que exercem as fases 3 e 4 no processo global de estabilização em aterros sanitários (CASTRO, 2001).

Do ponto de vista dos resíduos, as diversas fases da decomposição ocorrem simultaneamente, mas em pontos diferentes do aterro. Os resíduos recém dispostos, assim como aqueles localizados próximo à superfície, estão ainda submetidos a processos aeróbios. As camadas mais antigas e profundas já se encontram na fase metanogênica (SOUTO, 2009).

Nenhum aterro sanitário apresenta uma única fase distinta ou uma seqüência perfeitamente ordenada de fases. O que se verifica, é a presença de um conjunto de diferentes fases e idades associadas às várias células de um aterro. Igualmente, observase que a taxa de desenvolvimento através dessas fases pode variar em função do tempo de disposição, e das condições físicas, químicas e biológicas desenvolvidas dentro de 
cada célula. Assim, a presença de substâncias tóxicas pode produzir uma inibição da atividade microbiana enquanto uma compactação exagerada pode limitar a percolação da área e dos nutrientes através da massa de resíduos de uma célula, dificultando a bioconversão dos materiais orgânicos (SCHALCH, 1992).

Como explanado acima, a disposição dos resíduos sólidos urbanos em lixões, nos aterros controlados ou nos aterros sanitários, não evita a formação de subprodutos como gases $\left(\mathrm{CO}_{2}, \mathrm{H}_{2} \mathrm{~S}\right.$ e $\left.\mathrm{CH}_{4}\right)$, de lixiviados/percolados (mistura de chorume gerado pela degradação do material orgânico com água de chuva), que exigem um tratamento adequado, sob pena de criarem impactos ambientais e efeitos estéticos indesejados (BIDONE \& POVINELLI, 1999).

\subsubsection{FATORES QUE INFLUENCIAM A DIGESTÃO DA MATÉRIA ORGÂNICA EM ATERROS SANITÁRIOS}

Tanto fatores de ordem operacional (material de cobertura, compactação dos resíduos, profundidade do aterro, chuvas, composição dos resíduos) quanto fatores intrínsecos à atividade microbiológica, contribuem para alteração dos três parâmetros principais: temperatura, teor de umidade e $\mathrm{pH}$ dos resíduos aterrados. A toxicidade de metais também é um parâmetro relevante (CASTRO, 2001).

\section{Temperatura}

De acordo com BORZANI et al. (1975) nos aterros sanitários ocorrem sucessivamente dois processos biológicos: o aeróbio e o anaeróbio. Pelo fato de ser grande a quantidade de matéria sólida, por melhor que seja compactado o lixo, existe sempre certa quantidade de ar nos espaços intersticiais, responsável pela atividade respiratória durante certo tempo. Essa fase aeróbia pode ser dividida em etapas; a 
primeira dessas etapas realiza-se em ambiente ácido, havendo digestão de carboidratos simples, tais como os açúcares em geral.

A temperatura ideal desta fase situa-se em torno de $35^{\circ} \mathrm{C}$. A etapa seguinte, ainda aeróbia, realiza-se com temperaturas entre 60 e $65^{\circ} \mathrm{C}$, ocorrendo aí a decomposição das proteínas e de outros compostos orgânicos nitrogenados. Acompanha essa fase uma elevação de pH do meio, devido a formação de significativas quantidades de compostos amoniacais.

Finalmente, quando se verificar o decréscimo da temperatura, haverá condições para o desenvolvimento de bactérias e fungos anaeróbios, que promovem a decomposição da celulose e outros carboidratos mais resistentes. Durante o processo aeróbio de respiração ocorre uma forte redução da concentração de oxigênio - uma vez que o resíduo aterrado encontra-se isolado do ar atmosférico - e da produção de gás carbônico. Da redução da concentração resulta o aparecimento das condições de anaerobiose, dando lugar a uma nova seqüência biológica (CASTRO, 2001).

\section{pH}

Durante o processo de digestão anaeróbia uma das mais importantes exigências do meio ambiente para que o processo ocorra de forma satisfatória é o controle de $\mathrm{pH}$. A maioria dos pesquisadores considera que um $\mathrm{pH}$ com amplitude entre 6,8 e 7,2 corresponde a uma condição ótima de digestão (CASTRO, 2001).

POHLAND (1975) diz que as reações químicas e biológicas que ocorrem em aterros sanitários são função do $\mathrm{pH}$. Durante os estágios particulares da digestão anaeróbia a estabilização do pH depende da relação entre o ácido volátil, a alcalinidade do percolado e do dióxido de carbono contido no gás total produzido no processo. 
Portanto, a estabilização de resíduos em aterros sanitários ocorre de forma semelhante à da digestão anaeróbia.

Da atividade bacteriana aeróbia resulta a produção de $\mathrm{CO}_{2}$, o qual se dissolve na fase aquosa infiltrada, produzindo o ácido carbônico $\left(\mathrm{H}_{2} \mathrm{CO}_{3}\right)$, impondo um meio ácido.

Com a redução da concentração de oxigênio na massa de resíduos aterrada inicia-se, então, a primeira fase da digestão anaeróbia com formação de ácidos, com a predominância do ácido acético. Embora os ácidos produzidos sejam comumente fracos, eles contribuem significativamente para a acidez, especialmente se estiverem em altas concentrações.

Já na segunda fase da digestão anaeróbia, as bactérias metanogênicas metabolizam o acetato e a sua existência e o meio propício para sua reprodução garantem a manutenção de uma baixa concentração de ácidos orgânicos. $\mathrm{O}$ pH elevado, observado nos lixiviados velhos, é resultado da formação do bicarbonato de amônio.

\section{Teor de umidade}

De todos os fatores que influenciam a decomposição de resíduos em aterros sanitários, a umidade é o mais importante, já que disponibiliza um meio aquoso para o crescimento dos microrganismos responsáveis pelo processo de degradação e serve também como meio de transporte de nutrientes no interior do aterro.

Os resíduos domiciliares contêm naturalmente certo grau de umidade, que varia em função da composição, das condições climáticas e das práticas de coleta. Em decorrência da influência destes fatores observa-se uma variação acentuada nos valores do teor de umidade apresentados pela literatura. 
POHLAND \& KANG (1971) afirmam que as taxas das reações químicas e biológicas que ocorrem nos aterros aumentam com a elevação do teor de umidade encerrado nos resíduos.

\section{Metais pesados}

Se por um aspecto a diminuição da carga orgânica presente no lixiviado ao longo do tempo é justificada pela degradação anaeróbia dos resíduos, o abrandamento dos metais presentes no lixiviado ao longo do tempo se deve ao aumento do $\mathrm{pH}$ em lixiviados velhos.

SCHALCH (1992) estudou a correlação com a concentração da DQO com a concentração de manganês e de ferro, e verificou um abrandamento da concentração dos metais à medida que a matéria orgânica era decomposta.

\subsubsection{CRITÉRIOS PARA SELEÇÃO DE ÁREAS PARA ATERROS SANITÁRIOS}

$\mathrm{Na}$ escolha de uma área para implantação de aterros sanitários deve-se ter em conta a importância das características do meio físico. Uma área adequada significa menor gasto com preparo, operação e encerramento do aterro, significando também menores riscos ao meio ambiente e à saúde pública (IPT/CEMPRE, 2000).

O estudo para identificação de áreas que apresentem viabilidade ambiental para a instalação de um aterro sanitário pressupõe o atendimento do binômio tipologialocalização, ou seja, parte do princípio de que é necessário identificar, por um lado, as características inerentes ao empreendimento e, por outro, a capacidade de suporte do ambiente para recebê-lo. No caso do aterro sanitário, é possível assumir que a combinação de fatores como conformação do relevo, tipos de solos, formações geológicas, recursos hídricos, entre outros, determinam a capacidade (ou aptidão) do 
meio em acomodar certas atividades humanas de forma que os impactos dessas atividades não ultrapassem os níveis aceitos pela sociedade e/ou impostos pela legislação. Por outro lado, outros fatores como infra-estrutura de transporte ou presença de aglomerados urbanos são encarados como elementos que potencializam ou restringem a aptidão do meio para tais atividades.

De acordo com JARDIM (1995) os seguintes dados devem ser levantados na orientação da escolha de área para o aterro:

Dados gerais:

Dados populacionais: número de habitantes atuais e projeção da população futura;

Caracterização dos resíduos: quantidade e qualidade dos resíduos que se pretende dispor no aterro;

Informações sobre gerenciamento de resíduos no município: dados sobre varrição, acondicionamento, coleta e transporte dos resíduos.

Dados geológicos e geotécnicos:

Declividade: inclinações inferiores a $2 \%$ estão sujeitas a infiltração das águas de chuva enquanto valores superiores a 10\% estão sujeitas a erosões;

$>$ Textura do solo: o material deve possuir pelo menos $25 \%$ de finos (material passando na peneira de $0,075 \mathrm{~mm})$;

Permeabilidade: são indicados coeficientes entre $10^{-6}$ e $10^{-7} \mathrm{~cm} / \mathrm{s}$;

Nível do lençol freático: ideal é que a base do aterro se localize $3 \mathrm{~m}$ acima do ponto mais alto do lençol freático para os solos argilosos e uma distância maior para os solos arenosos; 
Substrato rochoso: solos com rochas calcáreas, dolomitas e rochas de cimentação carbonácea devem ser evitadas, pois possuem alto coeficiente de permeabilidade nas fraturas;

Dados sobre águas superficiais:

Identificar principais mananciais, bacias e corpos de água;

Identificar a qualidade e os usos dessas águas;

$>$ Verificar áreas de proteção de mananciais.

Dados sobre o clima:

Série histórica do regime de chuvas;

Direção e intensidade dos ventos.

Dados sobre legislação:

$>$ Pesquisar legislação nos níveis federal, estadual e municipal.

Dados sócio-econômicos:

Aspectos políticos;

Valor da terra;

Uso e ocupação do solo;

Distância do centro produtor de resíduos;

Integração à malha viária;

Aceitabilidade da população.

Uma sugestão de classificação das áreas investigadas é proposta por JARDIM (1995). Estas são classificadas em três categorias:

Recomendada: quando a área reúne condições para ser utilizada com segurança e baixo investimento; 
Recomendada com restrições: quando a área poderá ser utilizada conforme as normas vigentes necessitando, porém, de medidas complementares de médio investimento;

Não recomendada: neste caso, a área necessita de medidas complementares de alto investimento.

O Quadro 3.2.3.1 resume o modelo:

QUADRO 3.2.3.1: Critérios para seleção de área de aterro sanitário

\begin{tabular}{|c|c|c|c|}
\hline \multirow[b]{2}{*}{ Dados } & \multicolumn{3}{|c|}{ Classificacão das áreas } \\
\hline & Recomendada & $\begin{array}{l}\text { Recomendada com } \\
\text { restrições }\end{array}$ & Não recomendada \\
\hline Vida útil & Maior que 10 anos & \multicolumn{2}{|c|}{$\begin{array}{c}\text { Menor que } 10 \text { anos (a critério do órgão } \\
\text { ambiental) }\end{array}$} \\
\hline $\begin{array}{l}\text { Distância do centro } \\
\text { atendido }\end{array}$ & Maior que 10km & $10-20 \mathrm{~km}$ & Maior que $20 \mathrm{~km}$ \\
\hline $\begin{array}{c}\text { Zoneamento } \\
\text { ambiental }\end{array}$ & \multicolumn{2}{|c|}{$\begin{array}{c}\text { Áreas sem restrição no zoneamento } \\
\text { ambiental }\end{array}$} & $\begin{array}{c}\text { Unidades de } \\
\text { conservação } \\
\text { ambiental }\end{array}$ \\
\hline Zoneamento urbano & $\begin{array}{c}\text { Vetor de } \\
\text { crescimento } \\
\text { mínimo }\end{array}$ & $\begin{array}{c}\text { Vetor de } \\
\text { crescimento } \\
\text { intermediário }\end{array}$ & $\begin{array}{c}\text { Vetor de } \\
\text { crescimento } \\
\text { máximo }\end{array}$ \\
\hline $\begin{array}{c}\text { Densidade } \\
\text { populacional }\end{array}$ & Baixa & Média & Alta \\
\hline $\begin{array}{l}\text { Uso e ocupação do } \\
\text { solo }\end{array}$ & \multicolumn{2}{|c|}{ Áreas pouco utilizadas } & Ocupação intensa \\
\hline $\begin{array}{l}\text { Valorização da } \\
\text { terra }\end{array}$ & Baixa & Média & Alta \\
\hline $\begin{array}{l}\text { Aceitação da } \\
\text { população }\end{array}$ & Boa & Razoável & Inaceitável \\
\hline $\begin{array}{l}\text { Declividade do } \\
\text { terreno }\end{array}$ & $\begin{array}{c}3 \leq \text { declividade } \leq \\
20\end{array}$ & $\begin{array}{l}20 \leq \text { declividade } \leq \\
30\end{array}$ & $\begin{array}{c}\text { declividade }<3 \text { ou } \\
\text { declividade }>30\end{array}$ \\
\hline $\begin{array}{l}\text { Distância dos } \\
\text { cursos de água }\end{array}$ & Maior que $200 \mathrm{~m}$ & \multicolumn{2}{|c|}{$\begin{array}{c}\text { Menor que 200m com aprovação do órgão } \\
\text { ambiental responsável }\end{array}$} \\
\hline
\end{tabular}

Fonte: IPT/CEMPRE (2000)

De acordo com IPT/CEMPRE (2000), depois da seleção da área deverão ser conduzidas investigações de superfície e subsuperfície, divididas em: 
1) Técnicas de investigação indireta: interpretação de fotografias aéreas, métodos geofísicos (sísmica, sondagem elétrica vertical, e outras).

2) Técnicas de investigação direta: sondagens manuais ou mecânicas, ensaio de bombeamento e infiltração no local, ensaios em laboratório como análises físicoquímicas da água, granulometria, permeabilidade e compactação do solo.

\subsubsection{IMPACTOS AMBIENTAIS DEVIDO A ATERROS SANITÁRIOS}

Segundo da Resolução CONAMA 01/86, impacto ambiental é qualquer alteração das propriedades físicas, químicas e biológicas do meio ambiente, causada por qualquer forma de matéria ou energia, resultante das atividades humanas, que direta ou indiretamente afetam a saúde, a segurança e o bem estar da população; atividades sociais e econômicas; a biota; as condições estéticas e sanitárias do meio ambiente e as qualidades dos recursos ambientais.

De acordo com BIDONE \& POVINELLI (1999), as comunidades microbianas presentes em sistemas de disposição final de resíduos sólidos urbanos incluem bactérias hidrolíticas e fermentativas, acidogênicas, acetogênicas e arqueas metanogênicas, além de bactérias redutoras de sulfato e protozoários. Apenas na fase inicial, durante e logo após a deposição dos resíduos nos aterros, observam-se condições adequadas de crescimento de microrganismos aeróbios. O restante da degradação se dá sob ambiente anaeróbio.

A poluição das águas subterrâneas é um dos graves danos associados à desativação de empreendimentos das áreas de disposição de resíduos sólidos, que deve prever a recuperação das áreas degradadas com o objetivo de minimizar os danos ambientais, os quais devem ser reparados para que seja mantida a qualidade ambiental do local (SANCHEZ, 2001). 
Líquidos que contêm elevada carga orgânica, microrganismos, metais e outros compostos são formados durante a digestão da matéria orgânica. Se estes líquidos entrarem em contato com águas subterrâneas através da infiltração no solo ou com águas superficiais pelo escoamento superficial, podem alterar sua qualidade. Além disso, podem contaminar o solo no entorno, comprometendo o desenvolvimento da flora e conseqüentemente afetando a fauna (LOPES, 2007).

Outra fonte de contaminação é o metano, gás liberado na decomposição da matéria orgânica. Ele pode ser explosivo quando confinado em concentração de 5 a $15 \%$ no ar. Além disso, é um dos gases que contribui para o efeito estufa, sendo e 20 a 25 vezes mais efetivo que o dióxido de carbono.

Com o intuito de mitigar os impactos ambientais causados pela disposição dos resíduos sólidos urbanos em lixões, alguns procedimentos técnicos tornaram-se obrigatórios na implantação dos aterros sanitários. São eles: dispositivos de drenagem e tratamento de gases gerados, dispositivos de drenagem e tratamento de lixiviados, recobrimento diário e sistemático dos resíduos compactados com solo, selamento e impermeabilização mínima das células de aterro após alcance de sua altura útil (BIDONE \& POVINELLI, 1999).

Os Quadros 3.2.4.1 e 3.2.4.2 mostram a análise de riscos ambientais e à saúde humana realizado por PIVATO ${ }^{1}$ apud FERREIRA (2008), indicando a probabilidade de ocorrência de acidentes em um aterro sanitário.

\footnotetext{
${ }^{1}$ PIVATO, A. (2003) An overview of the fundamentals of risk assessment applied to the aftercare landfill impact. In: Proceedings of the $9^{\text {th }}$ international landfill symposium. Cagliari, Itália, 2003
} 
QUADRO 3.2.4.1: Probabilidade de ocorrência de acidentes decorrentes de um aterro

de resíduos - Riscos Ambientais

\begin{tabular}{|c|c|c|c|c|c|c|}
\hline \multicolumn{7}{|c|}{$\begin{array}{l}\text { Probabilidade de ocorrência de acidentes decorrentes de um aterro de resíduos - } \\
\text { Riscos Ambientais }\end{array}$} \\
\hline \multirow[b]{2}{*}{$\begin{array}{l}\text { Meio de } \\
\text { contaminação }\end{array}$} & \multirow[b]{2}{*}{$\begin{array}{l}\text { Evento } \\
\text { principal }\end{array}$} & \multirow[b]{2}{*}{ Contaminante } & \multirow[b]{2}{*}{ Evento } & \multicolumn{3}{|c|}{$\begin{array}{c}\text { Probabilidade de ocorrência de um } \\
\text { acidente }\end{array}$} \\
\hline & & & & $\begin{array}{l}\text { Durante a } \\
\text { operação } \\
\text { do aterro } \\
(20 \text { anos) }\end{array}$ & $\begin{array}{c}\text { Pós - } \\
\text { fechamento } \\
\text { do aterro } \\
\text { (de } 21 \text { até } \\
50 \text { anos) }\end{array}$ & $\begin{array}{c}\text { Longo } \\
\text { período } \\
\text { (após 50 } \\
\text { anos) }\end{array}$ \\
\hline \multirow{3}{*}{ Gasoso } & \multirow{3}{*}{$\begin{array}{l}\text { Fluxo de } \\
\text { biogás }\end{array}$} & \multirow{3}{*}{ Biogás } & $\begin{array}{l}\text { Concentração } \\
\text { perigosa de } \\
\text { contaminantes }\end{array}$ & 3 & 2 & 1 \\
\hline & & & $\begin{array}{l}\text { Inibição do } \\
\text { crescimento da } \\
\text { vegetação }\end{array}$ & 3 & 2 & 1 \\
\hline & & & $\begin{array}{l}\text { Inibição do } \\
\text { crescimento } \\
\text { animal }\end{array}$ & 2 & 1 & 0 \\
\hline \multirow{4}{*}{ Líquido } & \multirow{4}{*}{$\begin{array}{l}\text { Fluxo de } \\
\text { percolados }\end{array}$} & $\begin{array}{l}\text { Contaminação } \\
\text { da água } \\
\text { subterrânea }\end{array}$ & $\begin{array}{l}\text { Exceder as } \\
\text { concentrações } \\
\text { limites }\end{array}$ & 3 & 3 & 2 \\
\hline & & \multirow{3}{*}{$\begin{array}{l}\text { Contaminação } \\
\text { da água } \\
\text { superficial }\end{array}$} & $\begin{array}{l}\text { Exceder as } \\
\text { concentrações } \\
\text { limites }\end{array}$ & 2 & 2 & 2 \\
\hline & & & $\begin{array}{l}\text { Inibição do } \\
\text { crescimento da } \\
\text { vegetação }\end{array}$ & 2 & 2 & 2 \\
\hline & & & $\begin{array}{l}\text { Inibição do } \\
\text { crescimento } \\
\text { animal }\end{array}$ & 1 & 1 & 1 \\
\hline \multirow{3}{*}{ Sólido } & \multirow{3}{*}{ Solos } & \multirow{3}{*}{$\begin{array}{c}\text { Solos } \\
\text { contaminados }\end{array}$} & $\begin{array}{l}\text { Exceder as } \\
\text { concentrações } \\
\text { limites }\end{array}$ & 0 & 2 & 3 \\
\hline & & & $\begin{array}{l}\text { Inibição do } \\
\text { crescimento da } \\
\text { vegetação }\end{array}$ & 1 & 1 & 3 \\
\hline & & & $\begin{array}{l}\text { Inibição do } \\
\text { crescimento } \\
\text { animal }\end{array}$ & 1 & 1 & 3 \\
\hline
\end{tabular}

Fonte: PIVATO (2003) 
QUADRO 3.2.4.2: Probabilidade de ocorrência de acidentes decorrentes de um aterro

de resíduos - Riscos à Saúde Humana

\begin{tabular}{|c|c|c|c|c|c|c|}
\hline \multicolumn{7}{|c|}{$\begin{array}{l}\text { Probabilidade de ocorrência de acidentes decorrentes de um aterro de resíduos - } \\
\text { Riscos à Saúde Humana }\end{array}$} \\
\hline \multirow[b]{2}{*}{$\begin{array}{l}\text { Meio de } \\
\text { contaminação }\end{array}$} & \multirow[b]{2}{*}{$\begin{array}{l}\text { Evento } \\
\text { principal }\end{array}$} & \multirow[b]{2}{*}{ Contaminante } & \multirow[b]{2}{*}{ Evento } & \multicolumn{3}{|c|}{$\begin{array}{l}\text { Probabilidade de ocorrência de um } \\
\text { acidente }\end{array}$} \\
\hline & & & & $\begin{array}{l}\text { Durante a } \\
\text { operação } \\
\text { do aterro } \\
(20 \text { anos) }\end{array}$ & $\begin{array}{c}\text { Pós - } \\
\text { fechamento } \\
\text { do aterro } \\
\text { (de } 21 \text { até } \\
50 \text { anos) }\end{array}$ & $\begin{array}{c}\text { Longo } \\
\text { período } \\
\text { (após 50 } \\
\text { anos) }\end{array}$ \\
\hline \multirow{4}{*}{ Gasoso } & \multirow{4}{*}{$\begin{array}{l}\text { Fluxo de } \\
\text { biogás }\end{array}$} & \multirow{2}{*}{ Biogás } & $\begin{array}{c}\text { Inalação de gás } \\
\text { no interior das } \\
\text { residências }\end{array}$ & 3 & 2 & 0 \\
\hline & & & $\begin{array}{c}\text { Inalação de gás } \\
\text { no exterior das } \\
\text { residências }\end{array}$ & 3 & 2 & 0 \\
\hline & & \multirow{2}{*}{ Poeira } & $\begin{array}{c}\text { Inalação de gás } \\
\text { no interior das } \\
\text { residências }\end{array}$ & 2 & 1 & 0 \\
\hline & & & $\begin{array}{c}\text { Inalação de gás } \\
\text { no exterior das } \\
\text { residências }\end{array}$ & 2 & 1 & 0 \\
\hline \multirow{8}{*}{ Líquido } & \multirow{8}{*}{$\begin{array}{l}\text { Fluxo de } \\
\text { percolados }\end{array}$} & \multirow{7}{*}{$\begin{array}{l}\text { Contaminação } \\
\text { da água } \\
\text { subterrânea }\end{array}$} & $\begin{array}{c}\text { Ingestão de água } \\
\text { subterrânea } \\
\text { contaminada }\end{array}$ & 3 & 3 & 0 \\
\hline & & & $\begin{array}{l}\text { Contato dérmico } \\
\text { com água } \\
\text { subterrânea } \\
\text { contaminada } \\
\text { (durante banhos) }\end{array}$ & 3 & 3 & 2 \\
\hline & & & $\begin{array}{l}\text { Inalação de } \\
\text { vapores d'água } \\
\text { contaminada no } \\
\text { exterior das } \\
\text { residências }\end{array}$ & 3 & 3 & 2 \\
\hline & & & $\begin{array}{c}\text { Inalação de } \\
\text { vapores d'água } \\
\text { contaminada no } \\
\text { interior das } \\
\text { residências } \\
\end{array}$ & 3 & 3 & 2 \\
\hline & & & $\begin{array}{l}\text { Ingestão de } \\
\text { vegetais } \\
\text { irrigados com } \\
\text { água } \\
\text { contaminada } \\
\end{array}$ & 2 & 2 & 1 \\
\hline & & & $\begin{array}{l}\text { Ingestão de água } \\
\text { de irrigação }\end{array}$ & 2 & 2 & 1 \\
\hline & & & $\begin{array}{l}\text { Contato dérmico } \\
\text { com água de } \\
\text { irrigação } \\
\text { contaminada }\end{array}$ & 1 & 1 & 1 \\
\hline & & $\begin{array}{l}\text { Contaminação } \\
\text { da água } \\
\text { superficial }\end{array}$ & $\begin{array}{l}\text { Ingestão de água } \\
\text { de superfície } \\
\text { (durante a } \\
\text { natação) }\end{array}$ & 1 & 1 & 1 \\
\hline
\end{tabular}


Continuação do Quadro 3.2.4.2:

\begin{tabular}{|c|c|c|c|c|c|c|}
\hline \multicolumn{7}{|c|}{$\begin{array}{l}\text { Probabilidade de ocorrência de acidentes decorrentes de um aterro de resíduos - } \\
\text { Riscos à Saúde Humana }\end{array}$} \\
\hline \multirow[b]{2}{*}{$\begin{array}{l}\text { Meio de } \\
\text { contaminação }\end{array}$} & \multirow[b]{2}{*}{$\begin{array}{l}\text { Evento } \\
\text { principal }\end{array}$} & \multirow[b]{2}{*}{ Contaminante } & \multirow[b]{2}{*}{ Evento } & \multicolumn{3}{|c|}{$\begin{array}{l}\text { Probabilidade de ocorrência de um } \\
\text { acidente }\end{array}$} \\
\hline & & & & $\begin{array}{l}\text { Durante a } \\
\text { operação } \\
\text { do aterro } \\
\text { (20 anos) }\end{array}$ & $\begin{array}{c}\text { Pós - } \\
\text { fechamento } \\
\text { do aterro } \\
\text { (de } 21 \text { até } \\
50 \text { anos) }\end{array}$ & $\begin{array}{l}\text { Longo } \\
\text { período } \\
\text { (após 50 } \\
\text { anos) }\end{array}$ \\
\hline \multirow{7}{*}{ Líquido } & \multirow{7}{*}{$\begin{array}{l}\text { Fluxo de } \\
\text { percolados }\end{array}$} & \multirow{5}{*}{$\begin{array}{l}\text { Contaminação } \\
\text { da água } \\
\text { superficial }\end{array}$} & $\begin{array}{l}\text { Contato dérmico } \\
\text { com água de } \\
\text { superfície }\end{array}$ & 1 & 1 & 1 \\
\hline & & & $\begin{array}{l}\text { Ingestão de } \\
\text { vegetais } \\
\text { irrigados com } \\
\text { água } \\
\text { contaminada } \\
\end{array}$ & 2 & 2 & 1 \\
\hline & & & $\begin{array}{l}\text { Ingestão de água } \\
\text { de irrigação }\end{array}$ & 1 & 1 & 1 \\
\hline & & & $\begin{array}{l}\text { Contato dérmico } \\
\text { com água de } \\
\text { irrigação } \\
\text { contaminada }\end{array}$ & 1 & 1 & 1 \\
\hline & & & $\begin{array}{l}\text { Risco } \\
\text { microbiológico }\end{array}$ & 1 & 0 & 0 \\
\hline & & \multirow{2}{*}{$\begin{array}{l}\text { Vapores } \\
\text { contaminados }\end{array}$} & $\begin{array}{l}\text { Inalação de } \\
\text { vapores } \\
\text { contaminados no } \\
\text { exterior das } \\
\text { residências } \\
\end{array}$ & 1 & 1 & 1 \\
\hline & & & $\begin{array}{c}\text { Inalação de } \\
\text { vapores } \\
\text { contaminados no } \\
\text { interior das } \\
\text { residências }\end{array}$ & 1 & 1 & 1 \\
\hline \multirow{4}{*}{ Sólido } & \multirow{4}{*}{ Solos } & \multirow{4}{*}{$\begin{array}{l}\text { Solos } \\
\text { contaminados }\end{array}$} & $\begin{array}{c}\text { Contato dérmico } \\
\text { com solos } \\
\text { contaminados } \\
\end{array}$ & 1 & 1 & 3 \\
\hline & & & $\begin{array}{l}\text { Ingestão de solos } \\
\text { contaminados }\end{array}$ & 0 & 1 & 2 \\
\hline & & & $\begin{array}{l}\text { Ingestão de } \\
\text { vegetais } \\
\text { plantados em } \\
\text { solos } \\
\text { contaminados }\end{array}$ & 1 & 1 & 3 \\
\hline & & & $\begin{array}{c}\text { Risco } \\
\text { microbiológico }\end{array}$ & 1 & 0 & 0 \\
\hline
\end{tabular}

Fonte: PIVATO (2003) 


\subsection{LIXIVIADOS OU LÍQUIDOS PERCOLADOS}

\subsubsection{DEFINIÇÃO}

A NBR 8419/92 define sumeiro ou chorume como sendo o líquido produzido pela decomposição de substâncias contidas nos resíduos sólidos, que tem como características a cor escura, o mau cheiro e a elevada DBO (demanda bioquímica de oxigênio). A mesma norma delibera que lixiviação é o deslocamento ou arraste, por meio líquido, de certas substâncias contidas nos resíduos sólidos urbanos.

Após a precipitação pluviométrica sobre a massa de resíduos, o fluxo de água pelos vazios da massa sólida determina o seu contato e mistura com o chorume, resultando em um líquido que apresenta vários tipos de poluentes: compostos orgânicos biodegradáveis e não biodegradáveis, compostos nitrogenados, sólidos em suspensão e, em alguns casos, metais pesados e compostos tóxicos, entre outros. Este líquido, ou essa mistura de líquidos, conceitua-se modernamente como lixiviado (BIDONE, 2008).

Os líquidos percolados ocupam, juntamente com os gases, os interstícios existentes na fase sólida do aterro sanitário. Eles são produzidos como conseqüência de uma complexa gama de interações entre fatores relacionadas com o local de disposição do lixo (geológicos, hidrogeológicos, hidrometeorológicos, topográficos, composição do rejeito, compactação das células, impermeabilização e cobertura vegetal) (SCHALCH, 1992).

\subsubsection{CARACTERÍSTICAS E COMPOSIÇÃO}

A qualidade do lixiviado é resultado da interação entre tipo e intensidade de decomposição, o balanço hídrico e umidade do resíduo (EHRIG, 1983). As características do lixiviado mudam com o passar do tempo, porque, à medida que o aterro envelhece, ocorre uma mudança de breve período aeróbio para um longo período 
de decomposição anaeróbia, que apresenta duas fases distintas: uma fase ácida seguida por uma fase metanogênica (DIAMADOPOULOS, 1994).

O lixiviado da fase ácida, lixiviado "novo", é caracterizado por altos valores de poluentes orgânicos. Uma grande porção da matéria orgânica consiste em ácidos voláteis $(\mathrm{AV})$. Esses ácidos orgânicos de baixo peso molecular $(\mathrm{PM}<20)$ constituem a maioria da matéria orgânica do lixiviado com valores que atingem até $95 \%$ do COT (DIAMADOPOULOS, 1994). Amostras coletadas durante a fase ácida da decomposição apresentaram valores de $\mathrm{pH}$ baixo e concentrações de $\mathrm{DBO}_{5}$, DQO , nutrientes e metais pesados altas.

$\mathrm{Na}$ fase metanogênica da decomposição anaeróbia, arqueas produtoras de metano degradam os AV e reduzem a carga orgânica do lixiviado. O carbono orgânico que permanece após essa degradação é devido a substâncias de alto peso molecular. Estas substâncias são menos susceptíveis à degradação microbiológica e tendem a permanecer em lixiviados "velhos" (DIAMADOPOULOS, 1994). Amostras coletadas nesta fase mostram valores de $\mathrm{pH}$ entre 6,5 e 7,5, enquanto os valores de $\mathrm{DBO}_{5}$, DQO e nutrientes são menores quando comparados aos da fase ácida. A concentração de metais também será menor porque a maioria dos metais não é solúvel em $\mathrm{pH}$ neutro. $\mathrm{O} \mathrm{pH}$ do lixiviado não depende somente da concentração de ácidos presentes, mas também da pressão parcial de $\mathrm{CO}_{2}$ no gás do aterro que está em contato com o lixiviado (TCHOBANOGLOUS, THEISEN \& VIGIL, 1993).

A biodegradabilidade do lixiviado varia com a idade do aterro e pode ser verificada pela relação $\mathrm{DBO}_{5} / \mathrm{DQO}$. Inicialmente esta relação é igual ou maior a 0,5, e valores entre 0,4 e 0,6 dão um indicativo que a matéria orgânica presente no lixiviado é altamente biodegradável. Em aterros "velhos" a razão se mostra na faixa de 0,05 a 0,2. A taxa cai porque lixiviados de aterros "velhos" contêm quantidades de ácidos fúlvicos 
e húmicos, que não são facilmente biodegradáveis (TCHOBANOGLOUS, THEISEN \& VIGIL, 1993).

O lixiviado pode apresentar na sua composição compostos tóxicos, como amônia e metais, entre outros (DACANAL \& BEAL, 2007). Com relação às concentrações de nitrogênio, verificou-se, tanto no lixiviado bruto quanto nos efluentes dos filtros, que a quase totalidade encontra-se na forma $\mathrm{N}$-amoniacal (BIDONE et al, 2007).

TCHOBANOGLOUS, THEISEN \& VIGIL (1993) expõem algumas características dos lixiviados de aterros jovens e velhos na Tabela 3.3.2.1.

TABELA 3.3.2.1: Composição típica de lixiviados de aterros jovens e velhos

\begin{tabular}{|c|c|c|c|}
\hline \multirow[t]{2}{*}{ Constituinte } & $\begin{array}{r}\text { Aterro joven } \\
2 \mathbf{2} \text { a }\end{array}$ & $\begin{array}{l}\text { (menos que } \\
\text { los) }\end{array}$ & \multirow{2}{*}{$\begin{array}{l}\text { Aterro velho (mais que } 10 \\
\text { anos) }\end{array}$} \\
\hline & Valor médio & Valor típico & \\
\hline $\mathrm{DBO}_{5}(\mathrm{mg} / \mathrm{L})$ & $2000-30000$ & 10000 & $100-200$ \\
\hline DQO (mg/L) & $3000-60000$ & 18000 & $100-500$ \\
\hline $\begin{array}{l}\text { Sólidos suspensos totais } \\
\qquad(\mathrm{mg} / \mathrm{L})\end{array}$ & $200-2000$ & 500 & $100-400$ \\
\hline N-orgânico (mg/L) & $10-800$ & 200 & $80-120$ \\
\hline N-amoniacal (mg/L) & $10-800$ & 200 & $20-40$ \\
\hline Nitrato $(\mathrm{mg} / \mathrm{L})$ & $5-40$ & 25 & $5-10$ \\
\hline P-total (mg/L) & $5-100$ & 30 & $5-10$ \\
\hline Ortofosfato $(\mathrm{mg} / \mathrm{L})$ & $4-80$ & 20 & $4-8$ \\
\hline Alcalinidade $\left(\mathrm{mgCaCO}_{3} / \mathrm{L}\right)$ & $1000-10000$ & 3000 & $200-1000$ \\
\hline $\mathrm{pH}$ & $4,5-7,5$ & 6 & $6,6-7,5$ \\
\hline Cálcio (mg/L) & $200-3000$ & 1000 & $100-400$ \\
\hline Magnésio (mg/L) & $50-1500$ & 250 & $50-200$ \\
\hline Potássio (mg/L) & $200-1000$ & 300 & $50-400$ \\
\hline Sódio (mg/L) & $200-2500$ & 500 & $100-200$ \\
\hline Ferro total $(\mathrm{mg} / \mathrm{L})$ & $50-1200$ & 60 & $20-200$ \\
\hline
\end{tabular}


Nos aterros de países tropicais, a transição entre "lixiviado novo" e "lixiviado velho" parece acontecer dentro de um a dois anos após o início da operação, e não após cerca de cinco anos como acontece no clima temperado. Isto pode ser devido tanto à decomposição mais rápida dos resíduos em função das temperaturas mais elevadas e incidências de chuvas.

Em alguns casos o uso de sistemas de drenagem com brita na forma de colchões drenantes funcionam como filtros anaeróbios incorporados no aterro, removendo a carga orgânica facilmente biodegradável e colaborando para que o lixiviado rapidamente adquira características recalcitrantes (SOUTO \& POVINELLI, 2007).

A Tabela 3.3.2.2 mostra o levantamento realizado por SOUTO \& POVINELLI (2007) das características mais prováveis do lixiviado de aterros brasileiros.

TABELA 3.3.2.2: Características mais prováveis do lixiviado de aterros brasileiros

\begin{tabular}{|c|c|c|c|}
\hline Variável & Faixa máxima & Faixa mais provável & FVMP \\
\hline $\mathrm{pH}$ & $5,7-8,6$ & $7,2-8,6$ & $78 \%$ \\
\hline $\begin{array}{l}\text { Alcalinidade total }(\mathrm{mg} / \mathrm{L} \text { de } \\
\left.\qquad \mathrm{CaCO}_{3}\right)\end{array}$ & $750-11400$ & $750-7100$ & $69 \%$ \\
\hline Dureza $\left(\mathrm{mg} / \mathrm{L}\right.$ de $\left.\mathrm{CaCO}_{3}\right)$ & $95-3100$ & $95-2100$ & $81 \%$ \\
\hline Condutividade $(\mu \mathrm{S} / \mathrm{cm})$ & $2950-25000$ & $2950-17660$ & $77 \%$ \\
\hline $\mathrm{DBO}(\mathrm{mg} / \mathrm{L})$ & $<20-30000$ & $<20-8600$ & $75 \%$ \\
\hline $\mathrm{DQO}(\mathrm{mg} / \mathrm{L})$ & $190-80000$ & $190-22300$ & $83 \%$ \\
\hline Óleos e graxas (mg/L) & $10-480$ & $10-170$ & $63 \%$ \\
\hline Fenóis (mg/L de $\left.\mathrm{C}_{6} \mathrm{H}_{5} \mathrm{OH}\right)$ & $0,9-9,9$ & $0,9-4,0$ & $58 \%$ \\
\hline NTK (mg/L) & $80-3100$ & Não há & - \\
\hline N-amoniacal (mg/L) & $0,4-3000$ & $0,4-1800$ & $72 \%$ \\
\hline N-orgânico (mg/L) & $5-1200$ & $400-1200$ & $80 \%$ \\
\hline $\mathrm{N}$-nitrito $(\mathrm{mg} / \mathrm{L})$ & $0-50$ & $0-15$ & $69 \%$ \\
\hline N-nitrato (mg/L) & $0-11$ & $0-3,5$ & $69 \%$ \\
\hline
\end{tabular}


Continuação da Tabela 3.3.2.2:

\begin{tabular}{cccc}
\hline Variável & Faixa máxima & Faixa mais provável & FVMP \\
\hline P-total (mg/L) & $0,1-40$ & $0,1-15$ & $63 \%$ \\
Sulfeto (mg/L) & $0-35$ & $0-10$ & $78 \%$ \\
Sulfato (mg/L) & $0-5400$ & $0-1800$ & $77 \%$ \\
Cloreto (mg/L) & $500-5200$ & $500-3000$ & $72 \%$ \\
Sólidos totais (mg/L) & $3200-21900$ & $3200-14400$ & $79 \%$ \\
Sólidos totais voláteis (mg/L) & $630-20000$ & $630-5000$ & $60 \%$ \\
Sólidos totais fixos (mg/L) & $2100-14500$ & $2100-8300$ & $74 \%$ \\
Sólidos suspensos totais & $5-2800$ & $5-700$ & $68 \%$ \\
(mg/L) & & & \\
Sólidos suspensos voláteis & $5-530$ & $5-200$ & $62 \%$ \\
(mg/L) & $0,01-260$ & $0,01-65$ & $67 \%$ \\
Ferro (mg/L) & $0,04-2,6$ & $0,04-2,0$ & $79 \%$ \\
Manganês (mg/L) & $0,005-0,6$ & $0,05-0,15$ & $61 \%$ \\
Cobre (mg/L) & $0,03-1,1$ & $0,03-0,5$ & $71 \%$ \\
Níquel (mg/L) & $0,003-0,8$ & $0,003-0,5$ & $89 \%$ \\
Cromo (mg/L) & $0-0,26$ & $0-0,065$ & $67 \%$ \\
Cádmio (mg/L) & $0,01-2,8$ & $0,01-0,5$ & $0,01-1,5$ \\
Chumbo (mg/L) & & & \\
Zinco (mg/L) & & & \\
\hline
\end{tabular}

FVMP: frequiência de ocorrência dos valores mais prováveis

Fonte: SOUTO \& POVINELLI, 2007

Um lixiviado coletado durante a fase ácida de decomposição do aterro apresentará valores baixos de pH e altas concentrações de DBO, COT, DQO, nutrientes e metais pesados. Já o lixiviado da fase metanogênica apresentará pH entre 6,5 - 7,5, e menores valores de DBO, COT, DQO e nutrientes. As concentrações de metais pesados também serão menores porque a maioria dos metais é menos solúvel em $\mathrm{pH}$ neutro ou alcalino (TCHOBANOGLOUS, THEISEN \& VIGIL, 1993). 
Se um lixiviado apresenta características de lixiviado "novo", tanto tratamentos biológicos aeróbios como anaeróbios podem reduzir a alta concentração de matéria orgânica facilmente degradável. Se o lixiviado apresenta características de lixiviado "velho", ou mesmo após o lixiviado sofrer tratamento biológico, uma significante parte da matéria orgânica biodegradável já foi consumida. Sendo assim, tratamentos físicoquímicos podem ser empregados, antes do descarte do efluente (DIAMADOPOULOS, 1994).

De acordo com KJELDEN \& CHRISTENSEN (2001) e KJELDSEN et al. (2002), os constituintes dos líquidos percolados podem ser divididos em quatro grupos:

1) Matéria Orgânica dissolvida (MOD), expressa como Demanda Química de Oxigênio (DQO) ou Carbono Orgânico Total (COT), incluindo $\mathrm{CH}_{4}$, ácidos graxos voláteis (em particular na fase ácida) e muitos compostos recalcitrantes, por exemplo, compostos húmicos e fúlvicos;

2) Macronutrientes Inorgânicos: cálcio (Ca), magnésio $(\mathrm{Mg})$, sódio $(\mathrm{Na})$, potássio $(\mathrm{K})$, amônio $\left(\mathrm{NH}_{4}{ }^{+}\right)$, ferro $(\mathrm{Fe})$, manganês $(\mathrm{Mn})$, cloretos $\left(\mathrm{Cl}^{-}\right)$, sulfato $\left(\mathrm{SO}_{4}{ }^{2-}\right)$ e bicarbonato $\left(\mathrm{HCO}_{3}{ }^{-}\right)$, fósforo $(\mathrm{P})$;

3) Metais potencialmente tóxicos: cádmio $\left(\mathrm{Cd}^{2+}\right)$, cromo $\left(\mathrm{Cr}^{3+}\right)$, cobre $\left(\mathrm{Cu}^{2+}\right)$, chumbo $\left(\mathrm{Pb}^{2+}\right)$, níquel $\left(\mathrm{Ni}^{2+}\right)$ e zinco $\left(\mathrm{Zn}^{2+}\right)$;

4) Compostos Orgânicos Xenobióticos: que incluem uma variedade de hidrocarbonetos halogenados, compostos fenólicos, alcoóis, aldeídos, cetonas e ácidos carboxílicos, além de outras substâncias caracteristicamente tóxicas.

Outros compostos podem ser encontrados em menor concentração, como boro (B), arsênio (As), selênio (Se), bário (BA), lítio (Li), mercúrio (Hg) e cobalto (Co).

Alguns constituintes e características dos lixiviados são apresentados a seguir. 


\section{Matéria Orgânica Dissolvida - DQO}

A DQO é normalmente considerada como o total de contaminantes no lixiviado, e o entendimento da subdivisão da DQO é um importante pré-requisito na decisão do processo de tratamento do lixiviado (ZIYANG et al., 2009).

É uma medida da concentração de matéria orgânica em resíduos domésticos ou industriais. Esta análise permite a medida de um resíduo orgânico em termos da quantidade de oxigênio requerida para oxidação até dióxido de carbono e água. Ela baseia-se no fato de que toda matéria orgânica, com poucas exceções, pode ser oxidada através da ação de um forte agente oxidante sob condições ácidas. Os valores de DQO são quase sempre maiores que os valores de DBO e essa diferença tende a tornar-se cada vez maior quando se tem quantidades significativas de matéria orgânica resistente à oxidação biológica. A maior vantagem da análise de DQO é o curto período de tempo requerido para sua avaliação, pois enquanto para obtenção do valor da DBO são necessários pelo menos 5 dias, a DQO pode ser obtida em aproximadamente 3 horas. De acordo com o APHA, AWWA \& WPCF (2005), espécies inorgânicas reduzidas tais como íons ferrosos, manganosos, sulfetos, etc. também são oxidados na análise de DQO e amônia e seus derivados não são oxidados (CONTRERA, 2008).

Como já explicado anteriormente a DQO varia em função da idade do aterro. Maiores valores de DQO são encontrados em lixiviados "novos", enquanto valores menores são observados em lixiviados "velhos".

A composição da DQO em lixiviados de aterros sanitários pode variar de acordo com o tempo de disposição dos resíduos. A porcentagem de matéria orgânica no lixiviado decresce quanto maior for o tempo de disposição (ZIYANG et al., 2009).

Os componentes inorgânicos que podem contribuir para DQO são $\mathrm{Fe}^{2+}, \mathrm{Mn}^{2+}$, sulfetos e cloretos. 


\section{Ácidos Voláteis Totais - AVT}

Correspondem à fração dos ácidos graxos de cadeia curta e pequeno peso molecular, ou seja, com menos de 6 carbonos em sua cadeia. Podem ser destilados à pressão atmosférica. A Tabela 3.3.2.4 apresenta os ácidos voláteis e algumas de suas características:

TABELA 3.3.2.4: Ácidos Voláteis e suas principais características

\begin{tabular}{|c|c|c|c|c|c|c|c|}
\hline Ácido & $\begin{array}{l}\text { Fórmula } \\
\text { química }\end{array}$ & $\begin{array}{l}\text { Massa } \\
\text { molar } \\
(\mathrm{g} / \mathrm{mol})\end{array}$ & $\begin{array}{c}\text { Densidade } \\
\left(\mathrm{g} / \mathrm{cm}^{3}\right)\end{array}$ & $\begin{array}{c}\text { Pressão } \\
\text { de } \\
\text { vapor a } \\
1^{\circ} \mathrm{C} \\
(\mathrm{atm})\end{array}$ & $\begin{array}{c}\text { Ponto } \\
\text { de } \\
\text { ebulição } \\
\left({ }^{\circ} \mathrm{C}\right)\end{array}$ & $\mathbf{p K}_{\mathbf{a}}$ & $\begin{array}{c}\text { Solubilidade } \\
\text { em água } \\
\text { (g/L) }\end{array}$ \\
\hline $\begin{array}{l}\text { Metanóico } \\
\text { (fórmico) }\end{array}$ & $\mathrm{CH}_{2} \mathrm{O}_{2}$ & 46,03 & $1,220^{\left(20^{\circ} \mathrm{C}\right)}$ & 0,99 & 101 & $\begin{array}{l}3,75 \\
\left(25^{\circ} \mathrm{C}\right)\end{array}$ & $\begin{array}{l}\text { Muito } \\
\text { solúvel }\end{array}$ \\
\hline $\begin{array}{l}\text { Etanóico } \\
\text { (acético) }\end{array}$ & $\mathrm{C}_{2} \mathrm{H}_{4} \mathrm{O}_{2}$ & 60,05 & $1,045^{\left(25^{\circ} \mathrm{C}\right)}$ & 0,55 & 117,9 & $\begin{array}{l}4,76 \\
\left(25^{\circ} \mathrm{C}\right)\end{array}$ & $\begin{array}{l}\text { Muito } \\
\text { solúvel }\end{array}$ \\
\hline $\begin{array}{l}\text { Propanóico } \\
\text { (propiônico) }\end{array}$ & $\mathrm{C}_{3} \mathrm{H}_{6} \mathrm{O}_{2}$ & 74,08 & $0,988^{\left(25^{\circ} \mathrm{C}\right)}$ & 0,24 & 141,15 & $\begin{array}{l}4,87 \\
\left(25^{\circ} \mathrm{C}\right)\end{array}$ & $\begin{array}{l}\text { Muito } \\
\text { solúvel }\end{array}$ \\
\hline $\begin{array}{l}\text { Butanóico } \\
\text { (butírico) }\end{array}$ & $\mathrm{C}_{4} \mathrm{H}_{8} \mathrm{O}_{2}$ & 88,11 & $0,953^{\left(25^{\circ} \mathrm{C}\right)}$ & 0,092 & 163,75 & $\begin{array}{l}4,83 \\
\left(25^{\circ} \mathrm{C}\right)\end{array}$ & $\begin{array}{l}\text { Muito } \\
\text { solúvel }\end{array}$ \\
\hline $\begin{array}{l}\text { Isobutanóico } \\
\text { (isobutírico) }\end{array}$ & $\mathrm{C}_{4} \mathrm{H}_{8} \mathrm{O}_{2}$ & 88,11 & $0,968^{\left(20^{\circ} \mathrm{C}\right)}$ & - & 154,45 & $\begin{array}{l}4,84 \\
\left(20^{\circ} \mathrm{C}\right)\end{array}$ & $\begin{array}{l}\text { Muito } \\
\text { solúvel }\end{array}$ \\
\hline $\begin{array}{l}\text { Pentanóico } \\
\text { (valérico) }\end{array}$ & $\mathrm{C}_{5} \mathrm{H}_{10} \mathrm{O}_{2}$ & 102,13 & $0,934^{\left(25^{\circ} \mathrm{C}\right)}$ & 0,037 & 186,1 & $\begin{array}{l}4,83 \\
\left(20^{\circ} \mathrm{C}\right)\end{array}$ & $25^{\left(20^{\circ} \mathrm{C}\right)}$ \\
\hline $\begin{array}{l}\text { Isopentanóico } \\
\text { (isovalérico) }\end{array}$ & $\mathrm{C}_{5} \mathrm{H}_{10} \mathrm{O}_{2}$ & 102,13 & $0,931^{\left(20^{\circ} \mathrm{C}\right)}$ & - & 176,5 & $\begin{array}{l}4,77 \\
\left(25^{\circ} \mathrm{C}\right)\end{array}$ & $43^{\left(20^{\circ} \mathrm{C}\right)}$ \\
\hline $\begin{array}{l}\text { Hexanóico } \\
\text { (capróico) }\end{array}$ & $\mathrm{C}_{6} \mathrm{H}_{12} \mathrm{O}_{2}$ & 116,16 & $0,921^{\left(25^{\circ} \mathrm{C}\right)}$ & 0,014 & 205,2 & $\begin{array}{l}4,85 \\
\left(25^{\circ} \mathrm{C}\right)\end{array}$ & $9,67^{\left(20^{\circ} \mathrm{C}\right)}$ \\
\hline
\end{tabular}

Fonte: SAWYER et al. (2003) e CRC (2007) apud CONTRERA (2008) ${ }^{2}$

\footnotetext{
${ }^{2}$ SAWYER, C. N,; MCCARTY, P. L.; PARKIN, G. F. (2003) Chemistry for environmental enginnering and science. $5^{\text {th }}$ ed. Internacional edition. McGraw-Hill, Mew York, USA, 752p.; CRC (2007) Handbook of chemistry and hysics. Internet version $2007,87^{\text {th }} \mathrm{ed}$.
} 
Estes ácidos são produto final de processos fermentativos e hidrolíticos de gorduras, proteínas e carboidratos que constituíam a matéria orgânica. As concentrações de AVT nos lixiviados podem variar de acordo com a idade do aterro. Os lixiviados de aterros "jovens" costumam apresentar elevadas concentrações de AVT, porém a concentração desses ácidos pode ser muito baixa ou mesmo até inexistir em lixiviados de aterros mais velhos (CONTRERA, 2008).

A determinação e o acompanhamento das concentrações de ácidos voláteis são de extrema importância em processos de digestão ou tratamento anaeróbio, pois acúmulos de ácidos voláteis podem indicar um desequilíbrio do sistema. Além do que, podem acabar consumindo praticamente toda alcalinidade a bicarbonato do sistema, causando queda no valor do $\mathrm{pH}$, que poderá até ficar fora da faixa ótima para os sistemas anaeróbios (CONTRERA, 2008).

\section{pH}

$\mathrm{O}$ pH é uma medida da concentração de íons hidrogênio presentes na fase líquida. Ele é o resultado da interação entre as diversas substâncias dissolvidas na massa líquida. Como muitas dessas substâncias são produzidas ou consumidas pelos microrganismos, a biota presente no meio também age sobre o $\mathrm{pH}$. A recíproca é verdadeira, ou seja, a condição de $\mathrm{pH}$ também afeta processos químicos e biológicos. A condição de $\mathrm{pH}$ pode definir as rotas metabólicas que serão usadas pelos microrganismos, bem como quais microrganismos que podem estar predominando. Então, o pH pode ser usado como um indicativo das condições predominantes no meio em estudo (SOUTO, 2009).

$\mathrm{O} \mathrm{pH}$ afeta a atividade das enzimas e a toxicidade de muitos compostos. As formas não ionizadas costumam ser muito mais tóxicas que as formas ionizadas, pois 
atravessam com mais facilidade a membrana celular. $\mathrm{O}$ exemplo mais típico é a amônia (SOUTO, 2009).

Em aterros velhos ou com elevadas concentrações de $\mathrm{N}$-amoniacal, o tamponamento devido à amônia que possui $\mathrm{pK}$ em torno de 9,25, tende a levar os valores de $\mathrm{pH}$ para faixas alcalinas.

Um meio ácido aumenta a solubilidade de muitos constituintes, diminui a adsorção e aumenta a troca iônica entre o lixiviado e a matéria orgânica. Porém, valores de $\mathrm{pH}$ menores que 5,5 causam inibição total da produção de todos os gases no aterro, devido a inibição total da atividade biológica (MC BEAN, ROVERS E FARQUHAR, 1995).

\section{Alcalinidade}

Segundo METCALF \& EDDY (2003) a alcalinidade em águas residuárias é resultado da presença de hidróxicos $\left(\mathrm{OH}^{-}\right)$, carbonatos $\left(\mathrm{CO}_{3}{ }^{2-}\right)$ e bicarbonatos $\left(\mathrm{HCO}^{3-}\right)$ de elementos como cálcio, magnésio, sódio, potássio e amônia. Boratos, silicatos, fosfatos e ácidos fracos, com $\mathrm{pK}_{\mathrm{a}}$ superiores a 4,3 também contribuem com a alcalinidade. CONTRERA (2008) afirma que no caso específico dos lixiviados de aterros sanitários, a alcalinidade total está intimamente ligada às concentrações de Namoniacal, pois nos lixiviados a amônia aparece predominantemente na forma de bicarbonato de amônio.

POHLAND \& HARPER (1985) estudaram o comportamento da alcalinidade através do levantamento de dados da sua variação e sugerem que se possa associar as fases do aterro de acordo com a medida de alcalinidade:

Transição: $200-2500 \mathrm{mg} / \mathrm{LCaCO}_{3}$ 
Formação de ácidos: 140-9650 mg/LCaCO 3 (aumento esperado para formação de ácido volátil e dissolução de bicarbonato)

Fermentação metanogênica: $760-5050 \mathrm{mg} / \mathrm{LCaCO}_{3}$ (diminuição esperada para remoção de ácido volátil)

Maturação final: $200-3520 \mathrm{mg} / \mathrm{LCaCO}_{3}$

Variação total das fases: $140-9650 \mathrm{mg} / \mathrm{LCaCO}_{3}$

\section{$>$ Nitrogênio}

De acordo com METCALF \& EDDY (2003) as principais fontes dos compostos de nitrogênio são os compostos nitrogenados de origem animal e vegetal, nitrato de sódio de depósitos minerais e nitrogênio atmosférico. As formas mais comuns e importantes de nitrogênio em águas residuárias e seus correspondentes estados de oxidação no meio ambiente são: amônia $\left(\mathrm{NH}_{3},-\mathrm{III}\right)$, amônio $\left(\mathrm{NH}_{4}{ }^{+},-\mathrm{IV}\right)$, gás nitrogênio $\left(\mathrm{N}_{2}, 0\right)$, nitrito $\left(\mathrm{NO}_{2}{ }^{-},+\mathrm{III}\right)$ e nitrato $\left(\mathrm{NO}_{3}{ }^{-},+\mathrm{V}\right)$.

Em lixiviados de aterros sanitários a forma predominante de nitrogênio é o Namoniacal, na forma de bicarbonato de amônio e $\mathrm{N}$-amônia livre. $\mathrm{O}$ bicarbonato de amônio se forma no interior do aterro em meio anaeróbio quando a amônia formada pela decomposição da matéria orgânica é neutralizada pelo ácido carbônico formado pela reação entre a unidade do lixo e o dióxido de carbono também resultante da decomposição da matéria orgânica (CONTRERA, 2008).

Sendo o nitrogênio constituinte das proteínas, suas concentrações em lixiviados estão diretamente relacionadas aos percentuais de matéria orgânica presentes nos resíduos sólidos. Outras fontes menores são os fertilizantes, produtos de limpeza e para preservação da madeira (SOUTO, 2009). 
O NTK pode ser usado como substituto bastante prático da concentração de nitrogênio total presente no lixiviado de um aterro sanitário. O nitrogênio total engloba, além do nitrogênio orgânico e do nitrogênio amoniacal (medidos como NTK), o nitrito, o nitrato e eventuais outras formas oxidadas. Entretanto, as formas oxidadas só ocorrem em concentrações muito baixas, graças ao ambiente anaeróbio do aterro. $\mathrm{O}$ aporte de nitritos e nitratos é mínimo, a não ser que seja feita recirculação de lixiviado após este ter passado por um processo efetivo de nitrificação. Perdas na fase gasosa só aconteceriam na forma de $\mathrm{N}_{2}$, que é formado a partir de nitritos e nitratos (SOUTO, 2009).

\section{Fósforo}

O fósforo é um elemento fundamental aos processos energéticos dos seres vivos, sendo o nutriente limitante no caso de tratamento de lixiviados devido a suas concentrações máximas não serem superiores a poucas dezenas de miligramas por litro (EHRIG, 1983).

Praticamente todo o fósforo encontrado em lixiviados está na forma de ortofosfatos. Eles provêm principalmente da matéria orgânica (SOUTO, 2009).

\section{Metais}

Sempre existiu um mito de que lixiviados de aterros sanitários apresentavam sempre elevadas concentrações de metais dissolvidos. Em lixiviados com pH ácido, realmente podem ocorrer concentrações mais elevadas de alguns metais, mas nos lixiviados provenientes de aterros com mais de 2 anos de operação não se costuma observar valores baixos de $\mathrm{pH}$, principalmente por já estarem na fase metanogênica e 
por, geralmente, apresentarem elevadas concentrações de $\mathrm{N}$-amoniacal, que faz com que o pH se eleve (CONTRERA, 2008).

A saída de metais no lixiviado depende do balanço entre os mecanismos que concorrem para a sua solubilização e os que agem para o seu aprisionamento no interior do maciço. Entre estes mecanismos estão reações de oxidação e redução, precipitação e dissolução, a formação de complexos com substâncias orgânicas e íons inorgânicos, metilação, adsorção e biosorção. Todos esses processos, porém, dependem das condições de equilíbrio químico do meio de reação (SANTOS ${ }^{3}$ apud SOUTO, 2009).

Os metais encontrados no lixiviado não são necessariamente um sintoma de que há resíduos industriais sendo dispostos clandestinamente. Metais estão presentes em todos os materiais, inclusive nos próprios seres vivos. Os resíduos domésticos, ainda mais quando não separados de forma adequada na origem, podem ser uma fonte significativa de metais. Além disso, outra fonte importantíssima de metais, em especial o ferro, é o solo argiloso usado nas camadas de cobertura e nos sistemas de impermeabilização (SOUTO, 2009).

\section{Sólidos}

A maior parte dos sólidos em lixiviados encontra-se na forma dissolvida. Elevadas concentrações de STF em lixiviados de aterros sanitários podem ser um indicativo de elevada salinidade, o que em concentrações muito elevadas pode até ter algum efeito inibitório para microrganismos, devido ao efeito osmótico. Por outro lado, elevadas concentrações de STV é um indicativo de elevadas concentrações de matéria orgânica (CONTRERA, 2008).

\footnotetext{
${ }^{3}$ SANTOS, A. F. M. S. (2003) Caracterização, avaliação da biodegradabilidade aeróbia e anaeróbia e tratamento em reator UASB do chorume do aterro Muribeca. Recife, 2003. Dissertação de Mestrado - Programa de Pós-Graduação em Engenharia Civil do Centro de Tecnologia e Geociências, Universidade Federal de Pernambuco.
} 


\section{$>$ Condutividade}

Contribui para uma melhor compreensão das fases de estabilização da matéria orgânica em um aterro sanitário. Varia com a concentração total de substâncias ionizadas dissolvidas em um meio aquoso, com a temperatura, com a mobilidade e a valência dos íons e com as concentrações real e relativa de cada íon (SCHALCH, 1992).

Estudos de POHLAND \& HARPER (1985) sugerem que se possam associar as fases do aterro sanitário de acordo com a medida de condutividade:

Transição: $2450-3310 \mu \mathrm{mho} / \mathrm{cm}$

Formação de ácidos: 1600-17100 $\mu \mathrm{mho} / \mathrm{cm}$ (aumento esperado para mobilização de metais)

Fermentação metanogênica: 2900-7700 $\mu \mathrm{mho} / \mathrm{cm}$ (diminuição esperada para complexação de metais com sulfetos)

Maturação final: $1400-4500 \mu \mathrm{mho} / \mathrm{cm}$

Variação total das fases: $1400-17100 \mu \mathrm{mho} / \mathrm{cm}$

\subsubsection{BIODEGRADABILIDADE DO LIXIVIADO}

A biodegradabilidade inerente (ou potencial) do lixiviado deve ser verificada sob condições ideais - microbiota adaptada, inibição do crescimento microbiano (por compostos tóxicos), falta de microrganismos, condições ambientais inadequadas, recalcitrância (resistentes à ação microbiana) (SOUTO, 2009).

\section{Razão DBO/DQO}

A razão DBO/DQO muitas vezes é usada como um indicativo da biodegradabilidade do lixiviado. Isto, porém, é uma abordagem simplista. Quando o 
valor desta razão é alto, significa que a maior parte da matéria oxidável pode sê-lo por ação microbiana. Ou seja, razões DBO/DQO altas são de fato sinônimos de elevada biodegradabilidade do efluente em questão. Por outro lado, uma razão DBO/DQO baixa não necessariamente significa que os compostos ali presentes são pouco biodegradáveis, mas apenas que os microrganismos que atuaram no ensaio não foram capazes de consumi-los. Dentro desse quadro, é importante que sejam feitas análises complementares quando um efluente apresenta baixas razões DBO/DQO (SOUTO, 2009).

A estabilização da taxa DBO/DQO depende da degradação do resíduo e não do processo de lixiviação (KJELDEN \& CHRISTOPHERSEN, 2001).

\section{Razão STV/ST}

Baixas razões STV/ST não são indicativas de dificuldade de biodegradação. Uma vez que a matéria orgânica corresponde exatamente aos sólidos voláteis, a biodegradabilidade corresponde à fração dos sólidos voláteis que é consumida, independentemente da concentração de sólidos fixos. Além disso, não há necessariamente relação direta entre sólidos voláteis, DQO e DBO. A DBO será alta se os sólidos voláteis forem facilmente biodegradáveis, mas será baixa se eles forem recalcitrantes. Se não houver substâncias inorgânicas que conferem DQO, como metais reduzidos e cloretos, o valor da DQO estará ligado quase que unicamente aos sólidos voláteis e sua remoção implicará na remoção quase total da DQO (SOUTO, 2009).

\section{Razão SSV/SST}

Alguns autores usam a razão SSV/SST como estimativa do potencial de degradação biológica de um efluente. Esta idéia está baseada em um conceito advindo 
dos sistemas de lodos ativados, em que os flocos (biológicos) são suficientemente grandes para entrar na categoria de sólidos suspensos, ao passo que o material a ser degradado está predominantemente na forma dissolvida. Nesse caso, a medida de sólidos suspensos voláteis serve como uma boa estimativa da biomassa presente no reator. Já quando se faz caracterização de um efluente isto não é adequado. Como (em tese) ele ainda não passou por nenhum processo ou operação de tratamento, ele pode conter matéria orgânica na forma suspensa que não corresponde à biomassa. Caso haja microrganismos, eles dificilmente estarão agregados em flocos ou grânulos, pois não tiveram condições para tal. Estarão, na prática, numa condição de crescimento disperso. Quando o crescimento é disperso, as bactérias não são quantificadas como sólidos suspensos. Para reter bactérias é preciso usar membranas de 0,22 $\mu \mathrm{m}$. A membrana para sólidos suspensos deve ter poros com abertura inferior a $2 \mu \mathrm{m}$. Na prática se usa membranas com aberturas de 0,45 ou $1,2 \mu \mathrm{m}$, que permitem a passagem das bactérias. Assim sendo, não é correto estimar a biomassa presente no lixiviado com o uso da análise de sólidos suspensos (SOUTO, 2009).

\section{Relação AVT/DQO}

A relação AVT/DQO talvez seja a melhor relação para representar a biodegradabilidade anaeróbia de lixiviados de aterros sanitários. CONTRERA (2008) apresentou a relação entre biodegradabilidade obtida através de DQO e a relação a AVT/DQO do lixiviado do aterro de São Carlos, que resultou numa fiel distribuição dos pontos ao longo de uma reta, não deixando dúvidas de que além da relação AVT/DQO ser uma boa relação para estimar a biodegradabilidade, esta relação pode ser linear com a biodegradabilidade, o que é mais um ponto positivo do ponto de vista prático. 
A relação AVT/DQO tem a vantagem de ser obtida em um período de tempo menor em relação a DBO/DQO e STV/ST. Enquanto a DBO/DQO demora cerca de 5 dias e a STV/ST 26 horas para ser concluída, a AVT/DQO pode ser obtida em 3 horas (CONTRERA, 2008).

\subsubsection{TAXA DE GERAÇÃO DE LIXIVIADO E FATORES INFLUENTES}

\subsubsection{DINÂMICA DA ÁGUA NO ATERRO SANITÁRIO}

A água tem papel fundamental, já que é a responsável pela integração dos fenômenos que acontecem no aterro, seja transportando materiais de um ponto a outro ou promovendo reações químicas. Por isso, tanto a quantidade de água disponível quanto as características do seu escoamento (retornando ou não ao topo do aterro pelo sistema de recirculação) são determinantes para o desempenho da degradação dos resíduos sólidos.

A água no aterro tem origem tanto externa quanto interna. As fontes externas de água correspondem à infiltração das águas de chuva, do escoamento superficial e mesmo das águas subterrâneas. As fontes internas são a umidade natural dos resíduos e água resultante do processo de decomposição (CHEN E BOWERMAN , 1974).

Em um aterro sanitário a precipitação é o fator mais importante ao se considerar as entradas de água. As saídas são evaporação, escoamento superficial e escoamento de lixiviado. Parte da infiltração é armazenada no aterro - e o restante escoa na forma de lixiviado (EHRIG, 1983).

A precipitação infiltra-se pela camada de superfície do local da disposição. A porção que se infiltra na superfície, satisfaz às necessidades de retenção da água, a serem empregadas na evaporação do solo e transpiração da planta, e o excesso, filtra-se 
através das camadas inferiores de resíduo sólido, representando a infiltração propriamente dita (SCHALCH, 1984).

Os resíduos sólidos, inicialmente, agem como uma esponja e simplesmente absorvem a água. Entretanto, o material atinge um teor de umidade, conhecido como capacidade de campo ( L ld capacity), onde qualquer acréscimo de água adicional, resulta na percolação de igual quantidade de massa. Alguma percolação poderá formarse, antes que a capacidade de retenção tenha sido atingida, porque o lixo, não sendo homogêneo, apresenta canais, e alguns dos resíduos, também não absorvem a água prontamente (SCHALCH, 1984).

A água carrega consigo oxigênio dissolvido. Isso faz com que em períodos de precipitação intensa a concentração de microrganismos aeróbios aumente. Com isso, a decomposição aeróbia da matéria orgânica se intensifica. Essas alterações nas populações de microrganismos podem interferir na velocidade de degradação dos resíduos. Entretanto, não são suficientes para eliminar a predominância dos processos anaeróbios nas células de aterramento (MONTEIRO, JUCÁ E RÊGO, 2001).

Em períodos chuvosos se verifica uma diminuição das concentrações das diversas variáveis físico-químicas do lixiviado. Isso é causado essencialmente pela simples diluição causada pelos maiores volumes de água infiltrada. Cabe ressaltar que essa diluição não é função direta da precipitação. O aterro, como qualquer sistema natural, converte precipitação em vazão de tal maneira que o hidrograma é amortecido em relação ao hietograma. (MONTEIRO, JUCÁ E RÊGO, 2001). A Figura 3.3.3.1.1 ilustra a dinâmica da água em um aterro sanitário. 


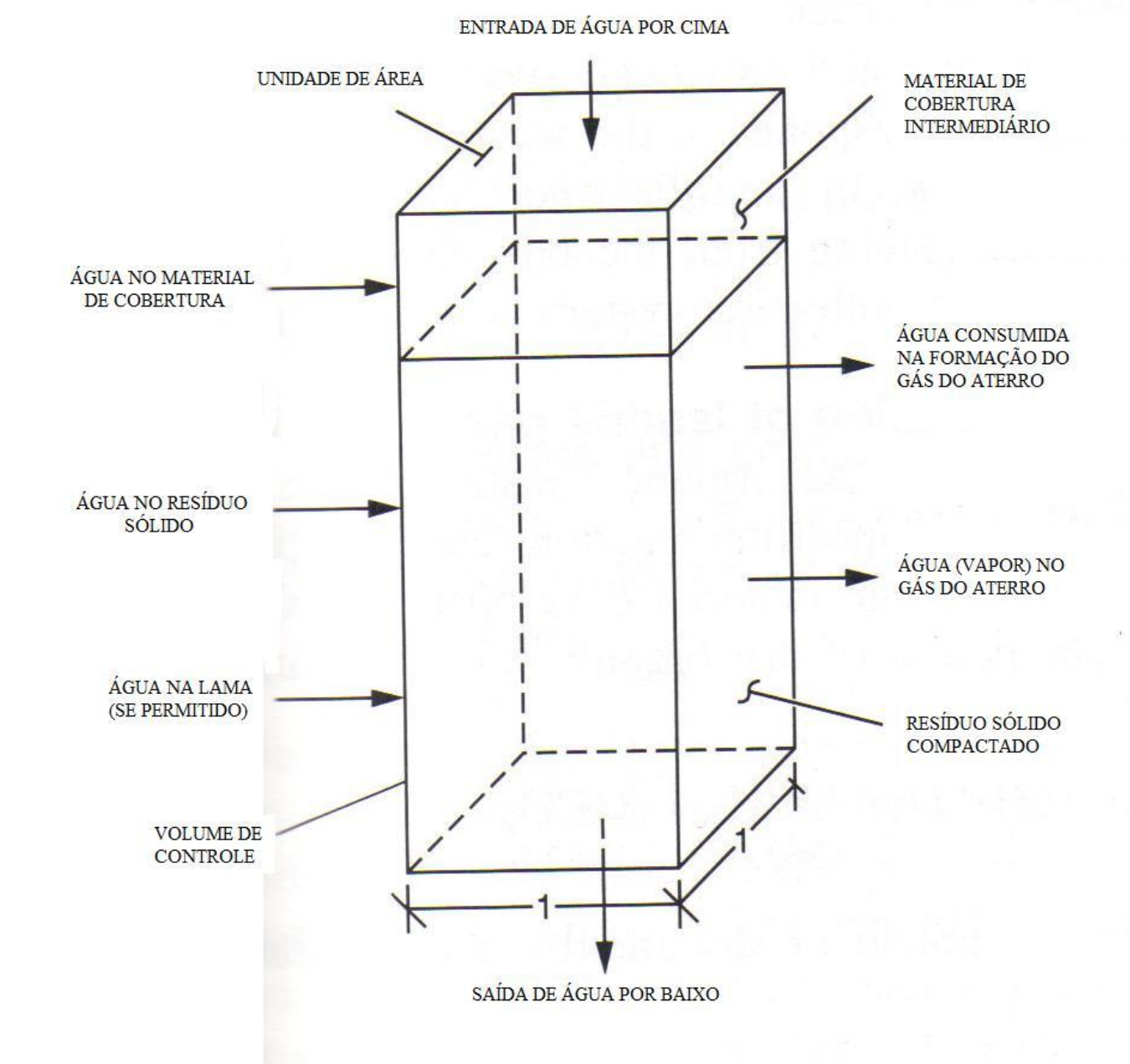

FIGURA 3.3.3.1.1: Dinâmica de água na formação de lixiviado em um aterro

Fonte: TCHOBANOGLOUS, THEISEN \& VIGIL (1993)

\subsubsection{TAXA DE GERAÇÃO}

Segundo IPT/CEMPRE (2000), durante a vida ativa de um aterro sanitário, a geração do lixiviado é influenciada por uma série de fatores, dos quais podemos ressaltar três grupos principais:

Fatores climatológicos e correlatos:

- regime de chuvas e precipitação pluviométrica anual;

- escoamento superficial;

- infiltração; 
- evapotranspiração e temperatura.

Fatores relativos ao resíduo sólido:

- composição;

- densidade;

- teor de umidade inicial.

Fatores relativos ao tipo de disposição:

- características de permeabilidade do aterro;

- idade do aterro;

- profundidade do aterro.

O volume de percolado que será produzido em um aterro sanitário depende da precipitação sobre a área do aterro, do escoamento superficial, da infiltração subterrânea, da umidade natural dos resíduos, do grau de compactação e da capacidade do solo em reter umidade. Na prática observa-se que a determinação “in loco” ou mesmo a estimativa segura de certos parâmetros, como grau de compactação, capacidade de retenção de umidade do material de cobertura e grau de umidade dos resíduos após seu aterramento, é difícil e imprecisa já que dependem fundamentalmente da forma de operação de cada aterro (CASTRO, 2001).

A produção de lixiviado em um aterro sanitário pode ou não ocorrer imediatamente após a disposição do resíduo. No caso de resíduos muito úmidos ou saturados de água a produção de lixiviado pode ocorrer imediatamente.

Um método simples para determinar a geração do lixiviado é adotado na Suíça. Segundo LIMA (1995), este método aplica coeficientes empíricos, que dependem do grau de compactação do lixo ou de seu peso específico:

Para aterros pouco compactados, com o resíduo aterrado apresentando um peso específico entre $4 \mathrm{kN} / \mathrm{m}^{3}\left(0,4 \mathrm{tf} / \mathrm{m}^{3}\right)$ e $7 \mathrm{kN} / \mathrm{m}^{3}\left(0,7 \mathrm{tf} / \mathrm{m}^{3}\right)$, espera-se que 25 a $50 \%$ 
da precipitação média anual que incide sobre a área do aterro transforme-se em lixiviado;

$>$ Para aterros mais compactados, com peso específico maior que $7 \mathrm{kN} / \mathrm{m}^{3}$ $\left(0,7 \mathrm{tf} / \mathrm{m}^{3}\right)$, espera-se que 15 a $25 \%$ da precipitação média anual que incide sobre a área do aterro transforme-se em lixiviado.

EHRIG (1988) reporta produções de lixiviados na faixa de 15 a $20 \%$ das precipitações registradas em diferentes aterros em diferentes épocas do ano.

\subsubsection{CONTAMINANTES DO LIXIVIADO}

Lixiviado de aterro sanitário é uma complexa mistura de poluentes; por isso é difícil mensurar o risco potencial de poluição aquática usando apenas técnicas comuns de identificação de poluentes. Ele é formado pela percolação de água de chuva no aterro. Enquanto a água passa por um aterro, compostos dissolvidos e sólidos suspensos são incorporados ao lixiviado. Muitos desses elementos são tóxicos aos organismos. A toxicidade de um lixiviado é produto do tipo de resíduo aterrado, o tipo de operação do aterro e do estágio de degradação da matéria orgânica dentro do aterro (THOMAS et L., 2009).

Amônia e alcalinidade são as fontes mais prováveis de contribuição de toxicidade do lixiviado. A toxicidade causada por esses fatores pode mascarar os efeitos tóxicos de xenobióticos (KJELDSEN et L., 2002). THOMAS et L.(2009) confirmaram esta afirmação e acrescentaram que metais pesados e compostos recalcitrantes são a causa de respostas adversas em testes com microrganismos.

As concentrações de poluentes nos lixiviados geralmente decrescem com o passar da idade do aterro sanitário. Entretanto, a concentração de amônia não decai na 
mesma proporção, constituindo o maior poluente no lixiviado (KJELDEN \& CHRISTOPHERSEN, 2001).

As rotas de destino de diferentes compostos químicos não são somente governadas por propriedades da matéria orgânica, mas também pelas características do aterro. Sugere-se que a emissão de lixiviado e gás são rotas de destino desses compostos. Os compostos orgânicos também podem ser transportados para fora do aterro por difusão de gás através da cobertura do solo superficial do aterro (KJELDEN \& CHRISTENSEN, 2001).

Estudos envolvendo lixiviados e sedimentos de aqüífero contaminado com lixiviado mostraram que não há degradação de hidrocarbonetos sob condições metanogênicas. Alguns compostos químicos como alcanos, cloreto de vinilo, diclorometano e freon-12 são emitidos juntamente com o gás do aterro por vários anos depois da disposição, enquanto outros compostos químicos como fenóis e clorobenzenos serão liberados no lixiviado. Compostos químicos com baixa solubilidade e baixa pressão de vapor, como o naftaleno podem permanecer no aterro por décadas (KJELDEN \& CHRISTENSEN, 2001).

Metais pesados presentes no lixiviado também são preocupantes devido à alta toxicidade. Eles estão geralmente presentes em baixas concentrações em lixiviados de aterros sanitários, porém podem possivelmente constituir um problema ambiental se o lixiviado atingir a água superficial ou subterrânea (BAUN \& CHRISTENSEN, 2004).

De acordo com as Resoluções CONAMA 357/05 e 397/08, os limites máximos permitidos de metais para lançamento de efluentes em corpos d'água estão na Tabela 3.3.4.1 e a Tabela 3.3.4.2 apresenta alguns metais pesados e suas respectivas concentrações observadas em lixiviados de aterros sanitários. 
TABELA 3.3.4.1: Limites máximos permitidos de concentração de metais para lançamento em corpos d’água

\begin{tabular}{cc}
\hline Metais pesados & Valor máximo $(\mathbf{m g} / \mathbf{L})$ \\
\hline Arsênio & 0,5 \\
Bário & 5,0 \\
Boro & 5,0 \\
Cádmio & 0,2 \\
Chumbo & 0,5 \\
Cianeto & 1,0 \\
Cromo trivalente & 1,0 \\
Cromo hexavalente & 0,1 \\
Cobre & 1,0 \\
Ferro & 15,0 \\
Manganês & 1,0 \\
Mercúrio & 0,01 \\
Níquel & 2,0 \\
Prata & 0,1 \\
Zinco & 5,0 \\
\hline
\end{tabular}

Fonte: CONAMA 357/05 e CONAMA 397/08

TABELA 3.3.4.2: Concentrações de metais pesados em lixiviados

\begin{tabular}{cc}
\hline Metais pesados & Concentração $(\mathbf{m g} / \mathbf{L})$ \\
\hline Arsênio & $0,01-1$ \\
Cádmio & $0,0001-0,4$ \\
Cromo & $0,02-1,5$ \\
Cobalto & $0,005-1,5$ \\
Cobre & $0,005-10$ \\
Chumbo & $0,001-5$ \\
Mercúrio & $0,00005-0,16$ \\
Níquel & $0,015-13$ \\
Zinco & $0,03-1000$
\end{tabular}


A atenuação de metais pesados durante a fase metanogênica do aterro é devido ao seqüestro da maioria das espécies solúveis de metais. Eles estão geralmente quelados à substâncias húmicas e ácidos fúlvicos, mais esta quelação pode ser alterada por mudanças no pH (THOMAS et al., 2009).

O balanço de metais pesados em aterros tem mostrado que menos de $0,02 \%$ dos metais recebidos nos aterros são lixiviados do aterro após 30 anos. Acredita-se que sorção e precipitação são mecanismos significantes na imobilização do metal (KJELDSEN et al., 2002). 


\section{MATERIAL E MÉTODOS}

\subsection{CARACTERIZAÇÃO DO ATERRO SANITÁRIO DE SÃO CARLOS}

O aterro sanitário do município de São Carlos está localizado a noroeste da área urbana, na Fazenda Guaporé, distante $15 \mathrm{~km}$ do centro da cidade. O acesso dá-se pela SP-310, Rodovia Washington Luiz, km 243, e por uma estrada de terra vicinal. A área total do aterro é 10,63 hectares. A Figura 4.1.1 é uma foto aérea do aterro e data de julho de 2009.

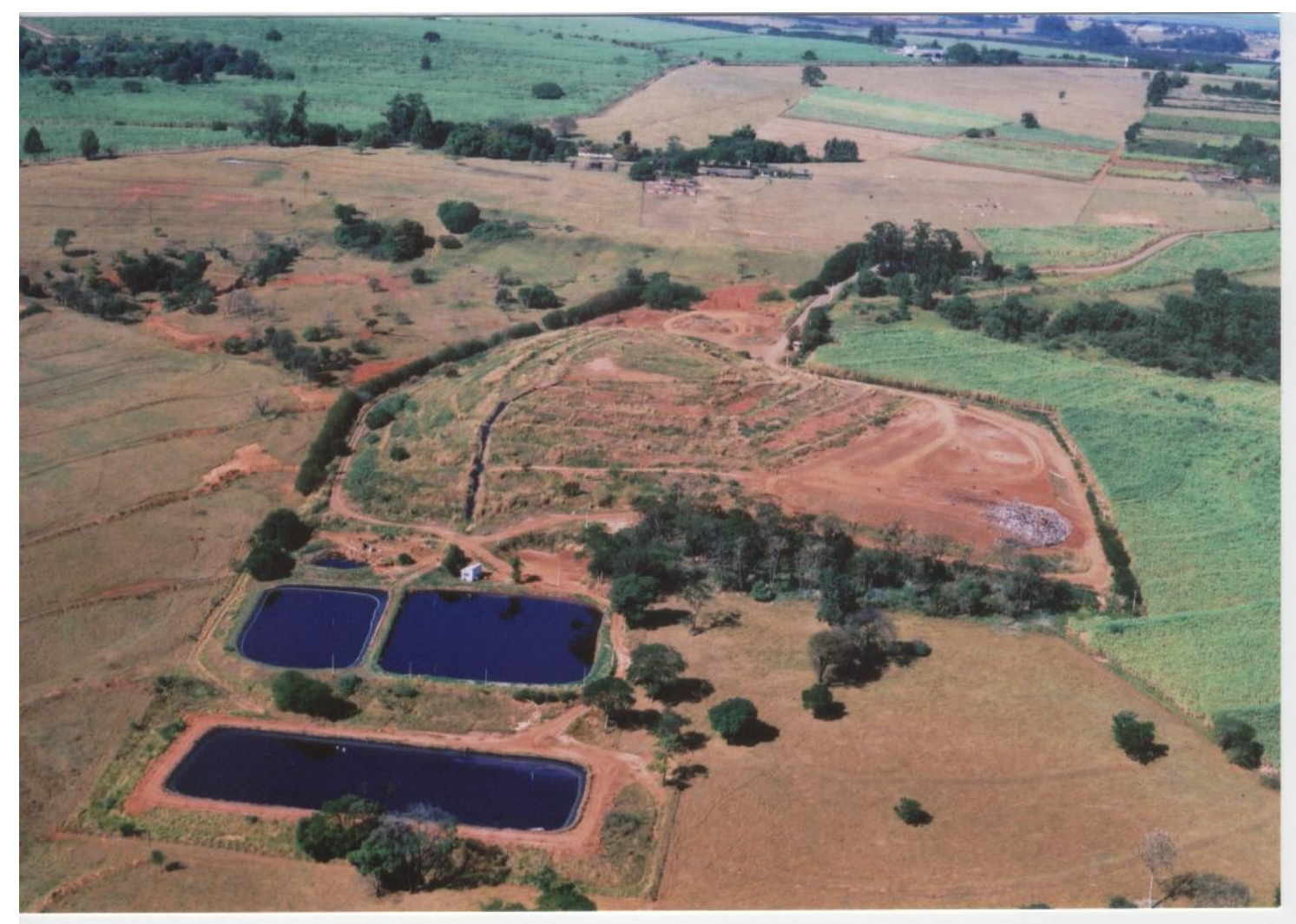

FIGURA 4.1.1: Foto aérea do aterro de São Carlos

Fonte: VEGA Engenharia Ambiental S.A.

De acordo com PMSC (2007), o aterro sanitário foi projetado para receber os resíduos sólidos de origem domiciliar coletados pelos serviços de coleta regular do município. Resíduos de origem industrial ou comercial que apresentam potencial 
periculosidade não são recebidos para disposição final no aterro sanitário. Resíduos de origem comercial podem ser recebidos até o volume de 100L, de construção civil até o volume de 50L e alguns resíduos especiais como animais mortos de pequeno porte e restos de móveis e colchões e ainda resíduos provenientes de serviços de varrição, poda e capina. São dispostos em média $6000 \mathrm{~m}^{3}$ mensais, cerca de 145 ton/dia, na operação do aterro.

No entorno do empreendimento verifica-se ocupação por plantação de cana-deaçúcar e pastagens. Nas proximidades do empreendimento encontram-se dois cursos d'água com pequena vazão: o Córrego Galdino (500 m de distância) e da Fazenda, ambos afluentes do rio Chibarro, o qual é afluente do rio Jacaré-Guaçu.

No local, existe uma infraestrutura, composta basicamente por:

$>$ portaria com guarita e sanitário;

$>$ água potável encanada; não há poço, o SAAE transporta a água em caminhão pipa e abastece a caixa d'água que tem capacidade de $5.000 \mathrm{~L}$;

$>$ energia elétrica na portaria e na edificação próxima às lagoas de chorume;

balança rodoviária para pesagem de caminhões, junto à portaria;

$>$ cerca em todo o perímetro do aterro;

$>$ via de acesso externo em bom estado de conservação;

vias internas de serviço;

sistema de drenagem de águas pluviais;

sistema de contenção de percolados;

$>$ coletores de gás com queimador na extremidade;

$>$ três lagoas para armazenamento de líquidos percolados.;

fossa séptica para tratamento dos efluentes sanitários; à medida que há necessidade a fossa é esgotada. 
Ainda de acordo com a PMSC (2007), o aterro foi inaugurado em junho de 1989 e desde 1995 é operado por uma empresa. Em 1997, a primeira célula teve sua capacidade de recebimento de resíduos esgotada, ampliando-se o aterro com a construção de uma área emergencial junto à primeira célula. Esta primeira área do aterro foi denominada "aterro antigo" para os fins desta pesquisa. Em 2002, iniciaram-se as atividades de outra célula devido ao esgotamento da célula anterior. Esta área foi denominada "1a ampliação". As primeiras células construídas receberam como impermeabilização apenas uma camada de argila em sua base e taludes. Em 2004 começou a ser operada uma nova área, chamada de " $2^{\mathrm{a}}$ ampliação". Por fim, em 2005, houve nova ampliação no aterro mediante a assinatura do Termo de Ajustamento de Conduta (TAC) junto a CETESB e ao Ministério Público. A nova célula foi impermeabilizada com manta de polietileno de alta densidade (PEAD) de 2,0mm de espessura.

Em 2008 deram-se início as obras da terceira ampliação do aterro. Esta será a última célula, com previsão de vida útil de 25 meses. Após o esgotamento desta célula o aterro será encerrado. Em todas as ampliações foi construído um "colchão drenante", ou seja, uma camada de brita de cerca de $30 \mathrm{~cm}$ foi disposta no fundo de cada ampliação. A Figura 4.1.2 exemplifica essas áreas do aterro.

Ao final das atividades do aterro será executada uma camada final de cobertura, com espessura mínima de $60 \mathrm{~cm}$ para maior proteção do maciço do aterro, seguido do plantio de gramíneas. Para o monitoramento geotécnico serão observados marcos a serem implantados, placas de recalque e inclinômetros. Durante a operação e após a desativação do aterro é previsto o monitoramento das águas superficiais e subterrâneas, realizando-se para tanto, coletas a montante e a jusante do corpo receptor para análises de parâmetros físico-químicos. O lixiviado também será avaliado. 


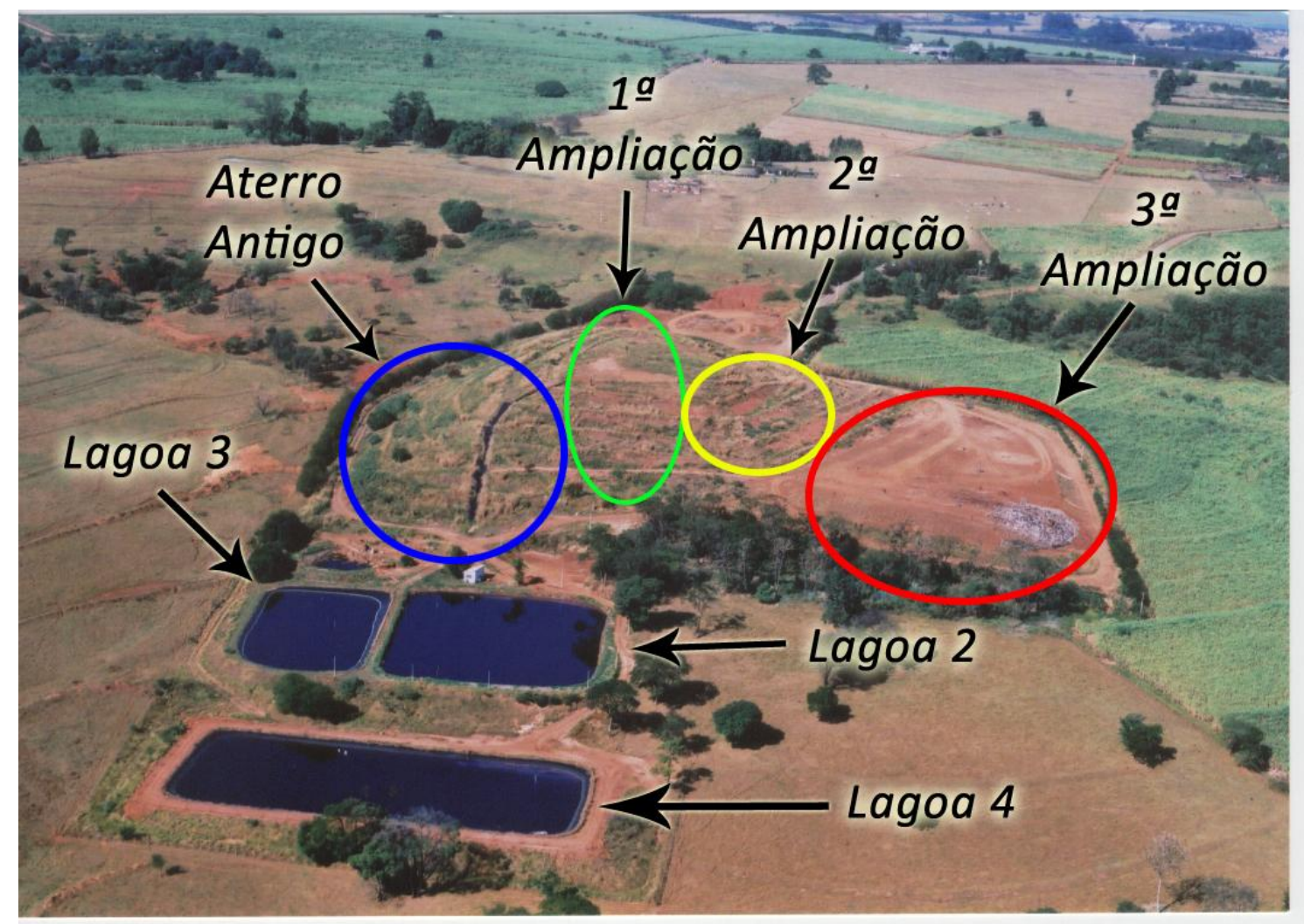

FIGURA 4.1.2: Áreas do aterro sanitário de São Carlos

\subsection{COLETA DAS AMOSTRAS}

As amostras de lixiviado foram coletadas no aterro sanitário de São Carlos. A

Figura 4.2.1 apresenta um esquema das instalações do aterro sanitário em 2009.

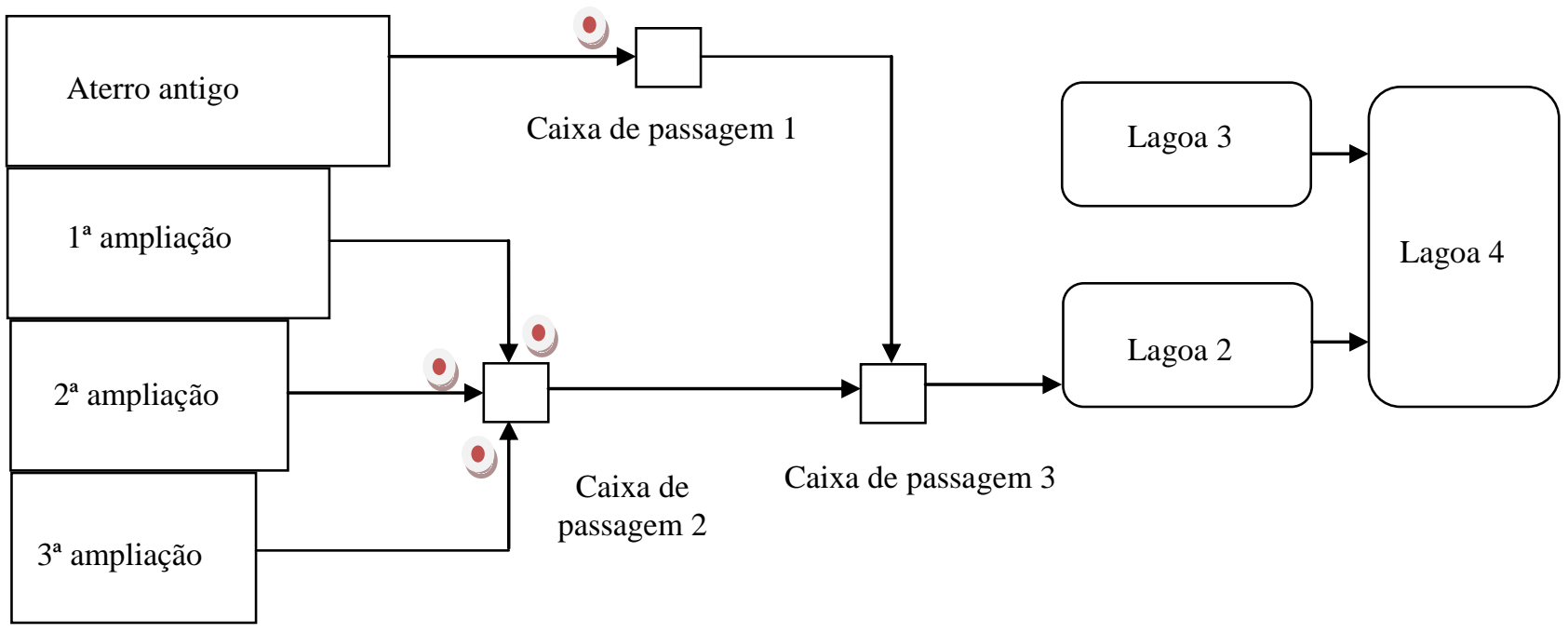

FIGURA 4.2.1: Instalações do aterro sanitário de São Carlos em 2009 
Como já mencionado durante a caracterização do aterro (item 4.1), a terceira ampliação ainda está em operação, com previsão de encerramento das atividades em outubro de 2010. As amostras foram coletadas em vários pontos do aterro.

$\mathrm{Na}$ caixa de passagem 2 foram amostrados os lixiviados das $1^{\mathrm{a}}, 2^{\mathrm{a}}$ e $3^{\mathrm{a}}$ ampliações, já que estes chegam à caixa por canalizações separadas. Esta caixa é ilustrada na Figura 4.2.2.

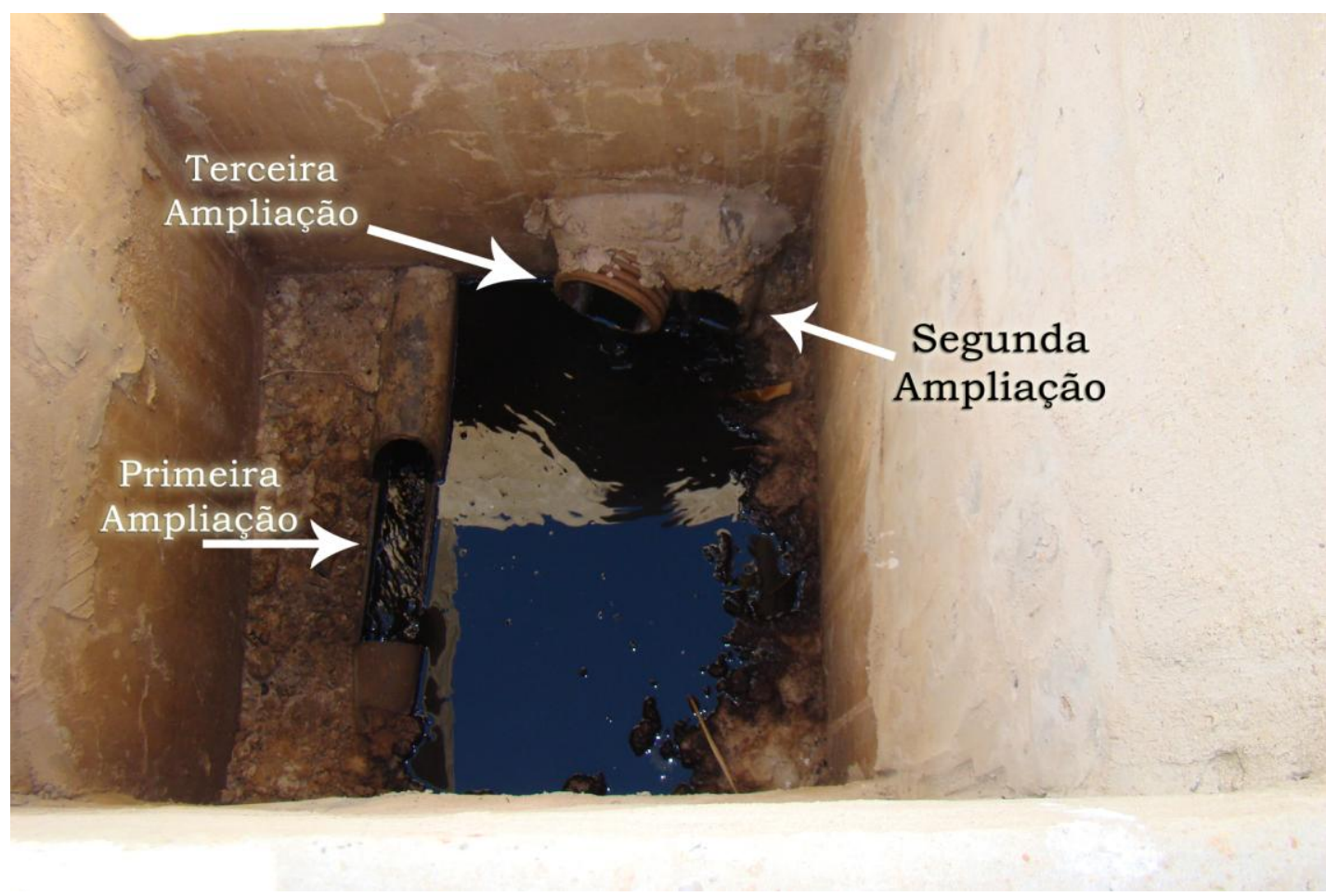

FIGURA 4.2.2: Caixa de passagem 2

Na caixa de passagem 1 foi coletado o lixiviado do aterro antigo. A Figura 4.2.3 exemplifica o lixiviado sendo coletado. 


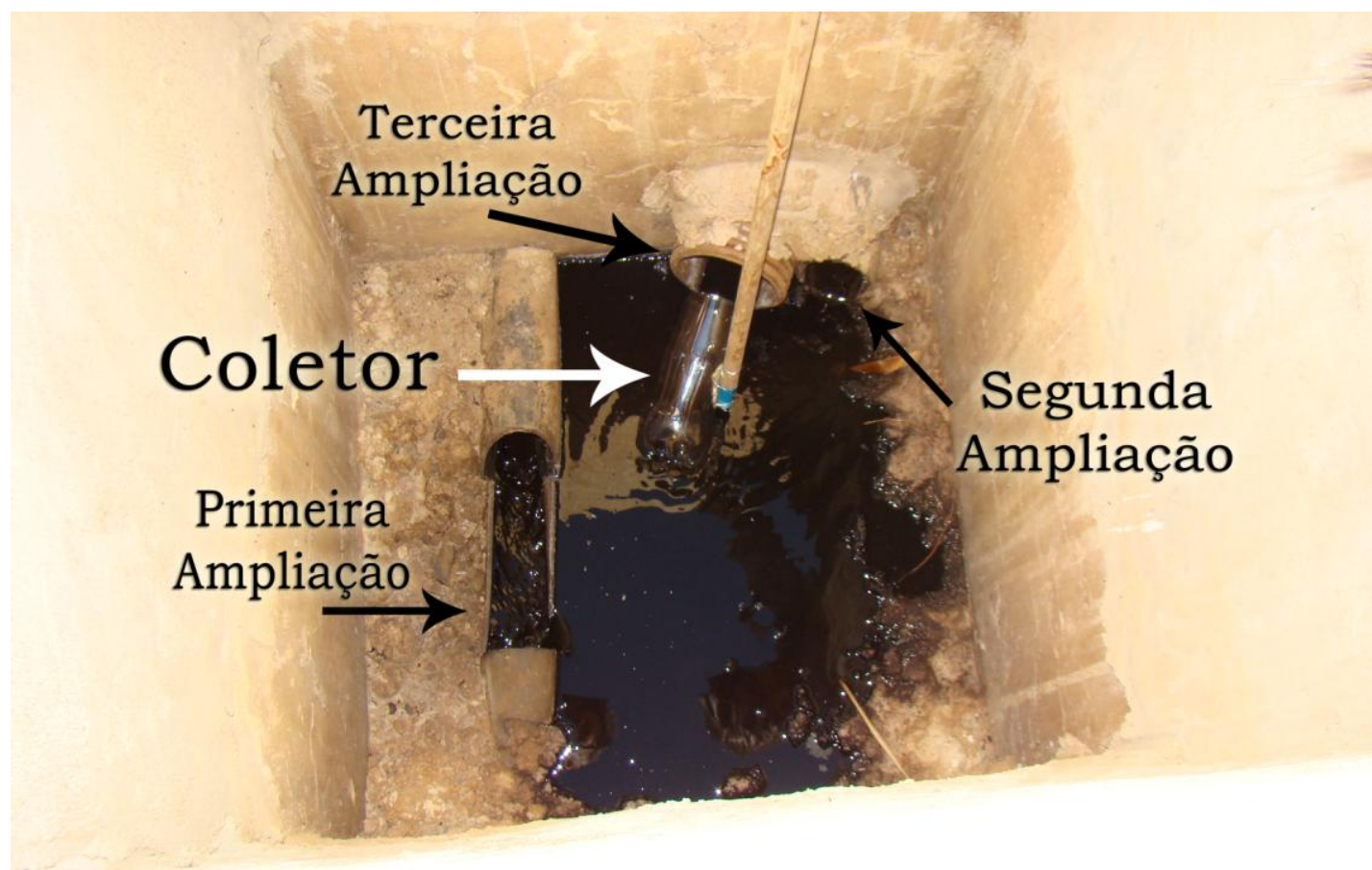

FIGURA 4.2.3: Lixiviado sendo coletado no aterro

O coletor foi concebido utilizando-se um cabo de vassoura com extensor. Isto foi necessário devido às grandes profundidades das canalizações dentro das caixas de passagem. A Figura 4.2.4 ilustra o coletor.

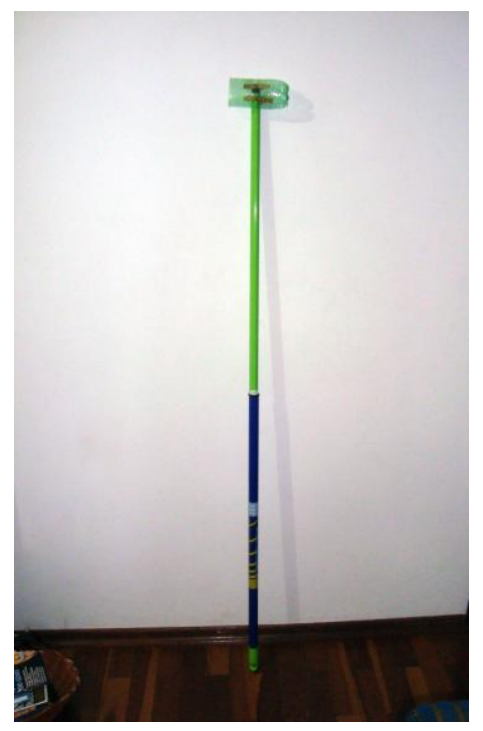

FIGURA 4.2.4: Coletor utilizado durante as coletas 
As amostras foram pontuais e simples. Em cada ponto foi coletado cerca de $1 \mathrm{~L}$ do lixiviado. Todas as amostras foram identificadas e armazenadas em recipiente isolante térmico até a chegada ao laboratório.

Não existem protocolos para amostragem, filtração e armazenamento de amostras de lixiviados (KJELDSEN et. al., 2002). Sendo assim, empregaram-se as recomendações para conservação de amostras aplicadas ao esgoto sanitário. Neste caso, a refrigeração foi suficiente, pois todas as análises eram realizadas em um prazo de 48 horas. Sabe-se por outros estudos e pela prática que o lixiviado não é tão facilmente degradado como o esgoto sanitário.

\subsection{ETAPAS DO EXPERIMENTO}

O experimento foi conduzido em 2 etapas:

$\mathrm{Na} \mathbf{1}^{\mathrm{a}}$ etapa foram coletadas amostras durante 11 semanas, uma vez por semana, totalizando 11 amostragens. Esta etapa foi realizada entre junho e setembro de 2009, período de seca e com menor vazão de lixiviado, devido a pouca precipitação.

Durante a $2^{\mathbf{a}}$ etapa amostrou-se lixiviado entre o fim de outubro até dezembro de 2009, período caracterizado pelo aumento da precipitação e conseqüente aumento da vazão de lixiviado.

O Quadro 4.3.1 apresenta os dias de coleta e quais pontos foram amostrados. Havia previsão de coleta no dia 08/12/09, mas devido às chuvas ficou impossível o acesso ao aterro. 
QUADRO 4.3.1: Dias de coleta e pontos amostrados

\begin{tabular}{|c|c|c|c|c|c|}
\hline & Data & $\begin{array}{c}1^{\mathbf{a}} \\
\text { ampliação }\end{array}$ & $\begin{array}{c}2^{\mathbf{a}} \\
\text { ampliação }\end{array}$ & $\begin{array}{c}3^{\mathbf{a}} \\
\text { ampliação }\end{array}$ & $\begin{array}{l}\text { Aterro } \\
\text { Antigo }\end{array}$ \\
\hline \multirow{12}{*}{$\begin{array}{l}0 \\
0 \\
\text { UI } \\
0 \\
0 \\
0 \\
0 \\
\frac{\sigma}{1} \\
\frac{1}{2}\end{array}$} & 03.06 .09 & $\mathrm{x}$ & $\mathrm{X}$ & $\mathrm{X}$ & \\
\hline & 17.06 .09 & $\mathrm{x}$ & $\mathrm{x}$ & $\mathrm{x}$ & \\
\hline & 25.06 .09 & $\mathrm{X}$ & $X$ & $\mathrm{X}$ & $\mathrm{X}$ \\
\hline & 01.07 .09 & $\mathrm{x}$ & $\mathrm{X}$ & $\mathrm{x}$ & $\mathrm{x}$ \\
\hline & 07.07 .09 & $\mathrm{x}$ & $\mathrm{x}$ & $\mathrm{x}$ & $\mathrm{X}$ \\
\hline & 14.07 .09 & $\mathrm{x}$ & $\mathrm{X}$ & $\mathrm{X}$ & $\mathrm{X}$ \\
\hline & 04.08 .09 & $\mathrm{X}$ & $\mathrm{X}$ & $\mathrm{x}$ & $\mathrm{x}$ \\
\hline & 11.08 .09 & $\mathrm{x}$ & $\mathrm{x}$ & $\mathrm{x}$ & $\mathrm{x}$ \\
\hline & 18.08 .09 & $\mathrm{X}$ & $\mathrm{X}$ & $\mathrm{X}$ & $\mathrm{X}$ \\
\hline & 24.08 .09 & $\mathrm{X}$ & $\mathrm{X}$ & $\mathrm{X}$ & $\mathrm{X}$ \\
\hline & 01.09 .09 & $\mathrm{x}$ & $\mathrm{X}$ & $\mathrm{x}$ & $\mathrm{x}$ \\
\hline & Data & $\begin{array}{c}\mathbf{1}^{\mathbf{a}} \\
\text { ampliação }\end{array}$ & $\begin{array}{c}2^{\mathbf{a}} \\
\text { ampliação }\end{array}$ & $\begin{array}{c}3^{\mathbf{a}} \\
\text { ampliação }\end{array}$ & $\begin{array}{l}\text { Aterro } \\
\text { Antigo }\end{array}$ \\
\hline \multirow{5}{*}{$\begin{array}{l}\mathbb{1} \\
3 \\
己 \\
0 \\
0 \\
0 \\
0 \\
0 \\
0 \\
01 \\
0\end{array}$} & 27.10 .09 & $\bar{x}$ & $\mathrm{X}$ & $\mathrm{x}$ & $\mathrm{X}$ \\
\hline & 10.11 .09 & $\mathrm{x}$ & $\mathrm{x}$ & $\mathrm{x}$ & $\mathrm{x}$ \\
\hline & 17.11 .09 & $\mathrm{x}$ & $\mathrm{x}$ & $\mathrm{x}$ & $\mathrm{x}$ \\
\hline & 24.11 .09 & $\mathrm{x}$ & $\mathrm{x}$ & $\mathrm{x}$ & $\mathrm{x}$ \\
\hline & 01.12 .09 & $\mathrm{x}$ & $\mathrm{x}$ & $\mathrm{x}$ & $\mathrm{x}$ \\
\hline
\end{tabular}

Não foram realizadas coletas entre setembro e o meio do mês de outubro porque se esperou que as chuvas começassem.

\subsection{ANÁLISES FÍSICO-QUÍMICAS REALIZADAS}

Todas as análises foram realizadas no Laboratório de Saneamento da USP em São Carlos

Com exceção dos ácidos voláteis, que foi determinado pela metodologia de DILALLO \& ALBERTSON (1961), todas as demais análises foram feitas de acordo com o Standard Methods for the Examination of Water and Wastewater APHA, AWWA, WPCF (2005). 
A Tabela 4.4.1 apresenta as variáveis consideradas na execução da parte experimental. A descrição dos métodos e de suas adaptações e modificações, para se adaptarem aos lixiviados são apresentadas no anexo A.

$\mathrm{Na} 2^{\mathrm{a}}$ etapa o destilador de nitrogênio quebrou e não foi possível dar continuidade aos exames de NTK e N amoniacal.

TABELA 4.4.1: Variáveis analisadas e métodos de análise do lixiviado

\begin{tabular}{cc}
\hline Variável & Método \\
\hline $\mathrm{pH}$ & Potenciometria \\
Alcalinidade total & Titulometria \\
Ácidos voláteis totais & Titulometria \\
DQO total & Digestão e espectrofotometria \\
Sólidos (série completa) & Filtração e gravimetria \\
Metais (Zn, Pb, Cd, Ni, Fe, & Absorção atômica e fotômetro \\
Mn, Cu, Cr, Na e K) & de chama \\
$\mathrm{N}$ amoniacal & Destilação e titulometria \\
NTK & Digestão, destilação e \\
& titulometria \\
\hline
\end{tabular}

4.5 OBTENÇÃO DE INFORMAÇÕES SOBRE O ATERRO SANITÁRIO E DADOS PLUVIOMÉTRICOS

As informações sobre o aterro sanitário foram obtidas junto à Prefeitura Municipal de São Carlos através do Sr. Douglas Minamisako e da VEGA Engenharia Ambiental S.A. pelo Sr. Fábio Andrade.

Um breve histórico das operações do aterro é apresentado na Tabela 4.5.1. 
TABELA 4.5.1: Histórico das operações do aterro

\begin{tabular}{cc}
\hline Ano & Informações \\
\hline 1988 & Confecção de EIA/RIMA \\
Junho 1995 a 2000 & Obra inicial, construção da lagoa 1 \\
Julho 2003 & $1^{\text {a Ampliação }}$ \\
Julho 2005 & $2^{\text {a Ampliação }}$ \\
Outubro 2008 & $3^{\text {a Ampliação }}$ \\
\hline
\end{tabular}

A Tabela 4.5.2 mostra a quantidade de resíduos aterrada durante os anos. Durante o ano de 1996 nem tudo que foi coletado chegou a ser disposto no aterro. Em todos os outros anos, exceto 1997 e 1998, a quantidade de resíduo aterrada foi maior que a quantidade coletada. Isto se deve ao fato de que o aterro também recebe resíduos de particulares.

O levantamento do histórico de operações do aterro bem como da quantidade de resíduos aterrada ano a ano serviu para confirmar que o volume de resíduos dispostos no aterro tem aumentado ao longo do tempo, porém este aumento é discreto. Considerase para todas as ampliações que o tipo de resíduo aterrado foi o mesmo e a forma de operação da área também. 
TABELA 4.5.2: Quantidade de resíduos aterrada durante os anos

\begin{tabular}{|c|c|c|c|c|c|}
\hline Ano & $\begin{array}{c}\text { Total Anual } \\
\text { Coletado } \\
(\mathbf{k g})\end{array}$ & $\begin{array}{c}\text { Média } \\
\text { Mensal } \\
\text { Coletada } \\
\text { (kg) }\end{array}$ & $\begin{array}{c}\text { Total } \\
\text { Anual } \\
\text { Disposto } \\
\text { no } \\
\text { Aterro } \\
\text { (kg) }\end{array}$ & $\begin{array}{c}\text { Média } \\
\text { Mensal } \\
\text { Aterrada } \\
\quad \text { (kg) }\end{array}$ & $\begin{array}{c}\text { Área de } \\
\text { operação }\end{array}$ \\
\hline 1995 & & & 22423,26 & 3203,32 & \\
\hline 1996 & 41744,53 & 3478,71 & 20962,23 & 3493,71 & \\
\hline 1997 & 45064,04 & 3755,34 & 45064,04 & 3755,34 & \\
\hline 1998 & 45794,13 & 3816,18 & 45794,13 & 3816,18 & ATERRO \\
\hline 1999 & 46826,23 & 3902,19 & 55578,14 & 4631,51 & ANTIGO \\
\hline 2000 & 48423,79 & 4035,32 & 57478,23 & 4789,85 & \\
\hline 2001 & 49210,39 & 4100,87 & 57954,02 & 4829,50 & \\
\hline 2002 & 50118,10 & 4176,51 & 56291,08 & 4330,08 & \\
\hline 2003 & 46218,69 & 3851,56 & 51987,27 & 3999,02 & $\begin{array}{c}1^{\mathrm{a}} \\
\text { AMPLIAÇÃO }\end{array}$ \\
\hline 2004 & 47818,10 & 3984,84 & 52965,23 & 4074,25 & \\
\hline 2005 & 49280,12 & 4106,68 & 53899,85 & 4146,14 & $2^{a}$ \\
\hline 2006 & 52389,18 & 4365,77 & 55782,57 & 4290,97 & AMPLIAÇÃO \\
\hline $2007^{*}$ & 34944,73 & 4368,09 & 50508,26 & 4591,66 & \\
\hline $2008^{*}$ & 18714,51 & 4678,63 & 22270,82 & 4454,16 & $3^{\mathrm{a}}$ \\
\hline $2009^{* *}$ & 46410,96 & 4641,10 & 52539,27 & 5253,93 & AMPLIAÇÃO \\
\hline
\end{tabular}

* De setembro de 2007 à agosto de 2008, o aterro sanitário não recebeu resíduos, sendo utilizado somente como estação de transbordo. O resíduo era encaminhado para o aterro sanitário de Guatapará.

** Até outubro de 2009

Os dados pluviométricos foram obtidos na Estação Pluviométrica da Embrapa Pecuária Sudeste na Fazenda Canchim em São Carlos. A localização da estação pluviométrica em relação ao aterro sanitário é apresentada na Figura 4.5.1. 


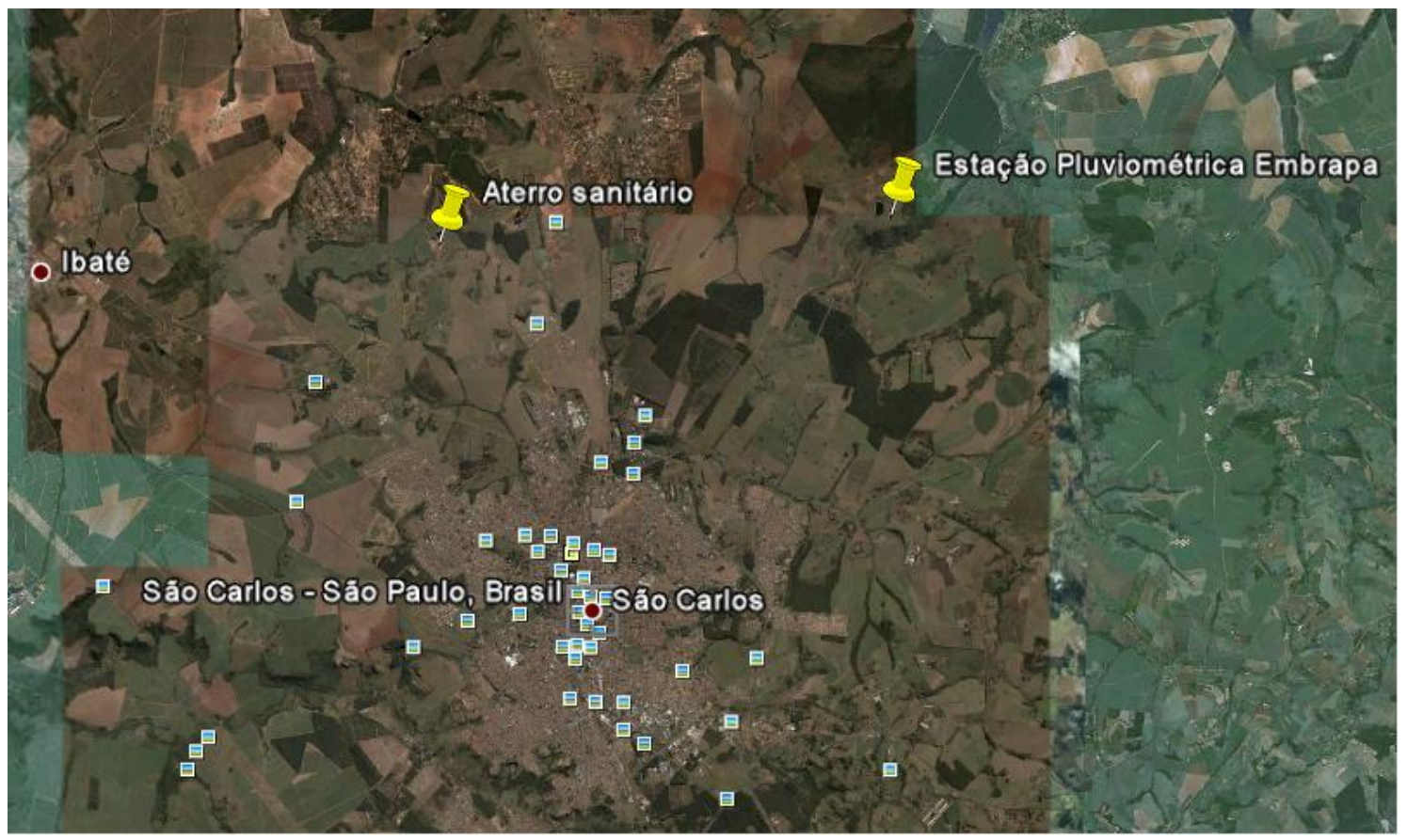

FIGURA 4.5.1: Localização da estação pluviométrica em relação ao aterro sanitário 


\section{RESULTADOS E DISCUSSÃO}

Como descrito no capítulo 4, foram amostrados os lixiviados durante o período de seca e o período chuvoso.

Em todos os gráficos é possível visualizar as concentrações dos parâmetros e a precipitação acumulada durante a semana anterior ao dia da coleta, ou seja, na coleta do dia 25.06.09 a precipitação plotada é referente à precipitação acumulada no período de 18.06.09 à 25.06.09 e assim por diante. Optou-se por proceder assim porque a precipitação que atinge o aterro não tem um efeito somente momentâneo, perdurando durante certo período.

A discussão dos resultados foi feita considerando-se a influência da precipitação e o tempo de disposição dos resíduos. Em todas as figuras é possível visualizar as médias obtidas para cada ponto, sendo o número entre parênteses os respectivos desvios padrões.

$5.1 \mathrm{pH}$

O comportamento do pH é apresentado na Figura 5.1.1. 


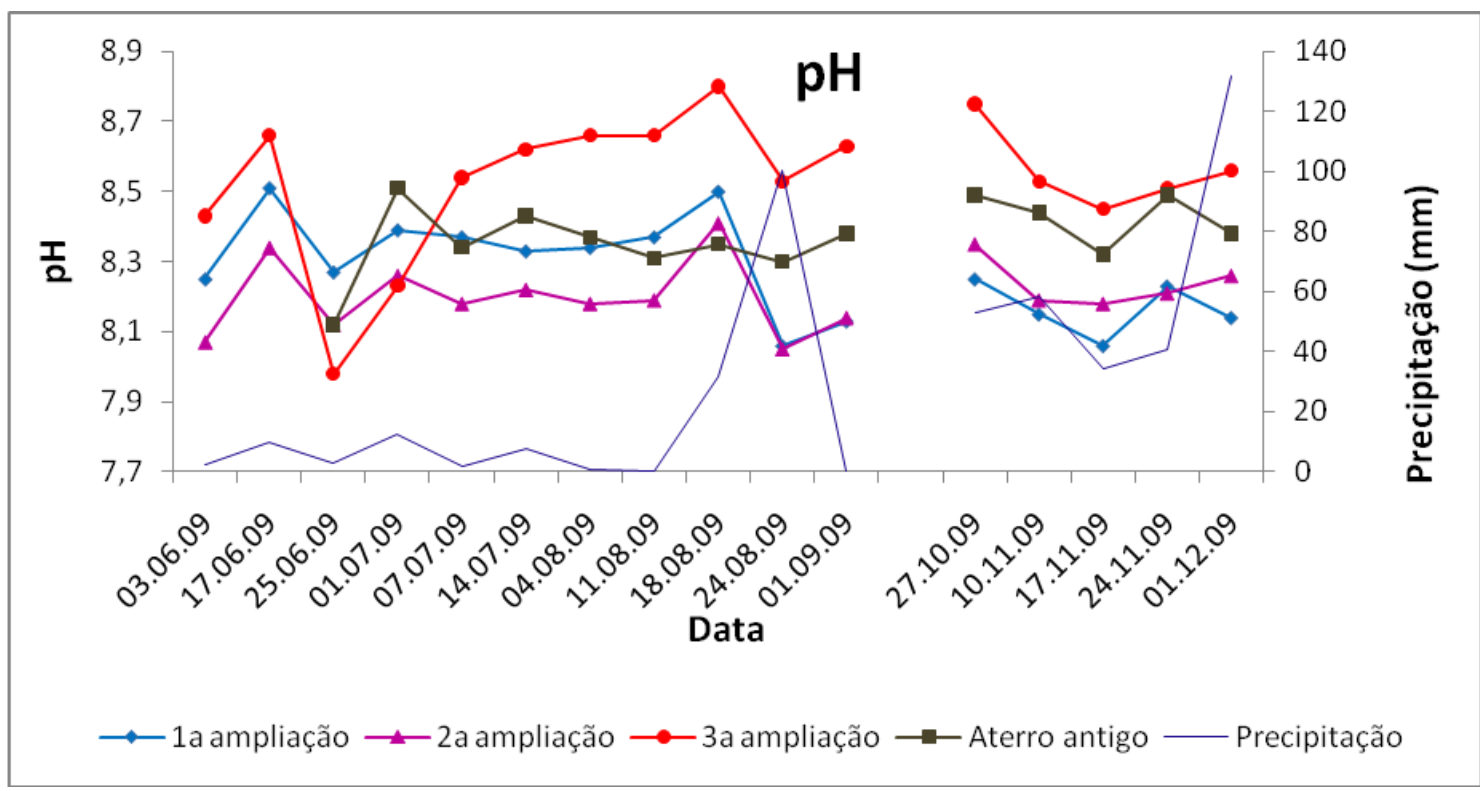

\begin{tabular}{ccccc}
\hline Média & $\begin{array}{c}1^{\mathrm{a}} \\
\text { ampliação }\end{array}$ & $\begin{array}{c}2^{\mathrm{a}} \\
\text { ampliação }\end{array}$ & $\begin{array}{c}3^{\mathrm{a}} \\
\text { ampliação }\end{array}$ & $\begin{array}{c}\text { Aterro } \\
\text { antigo }\end{array}$ \\
\hline \multirow{2}{*}{ Seco } & 8,32 & 8,20 & 8,52 & 8,35 \\
& $(0,14)$ & $(0,11)$ & $(0,23)$ & $(0,11)$ \\
\hline \multirow{2}{*}{ Chuvoso } & 8,17 & 8,24 & 8,56 & 8,42 \\
& $(0,08)$ & $(0,07)$ & $(0,11)$ & $(0,07)$ \\
\hline
\end{tabular}

* ( ) Desvio padrão

FIGURA 5.1.1: Comportamento do $\mathrm{pH}$

Em todos os pontos de amostragem o pH variou entre 8 e 9. Valores de $\mathrm{pH}$ acima de 8 são característicos de lixiviados em estágio avançado de degradação da matéria orgânica. É interessante ressaltar que o pH da $3^{\mathrm{a}}$ ampliação, apesar desta célula ainda receber resíduos, apresentou comportamento semelhante aos dos outros pontos de coleta.

A precipitação acumulada na semana anterior a coleta do dia 24.08 .09 interferiu somente nos valores de $\mathrm{pH}$ medidos nas ampliações. Estes pontos apresentaram diminuição no valor do $\mathrm{pH}$ enquanto o aterro antigo não teve seu $\mathrm{pH}$ alterado pela precipitação, talvez por se tratar da parte mais estabilizada do aterro, em termos de decomposição da matéria orgânica. 
No período chuvoso, os valores de $\mathrm{pH}$ encontrados foram todos superiores a 8 . Este valor alto de $\mathrm{pH}$ pode ser justificado pela presença do bicarbonato de amônio, substância com caráter altamente alcalino. Nem mesmo a alta precipitação acumulada na semana da coleta do dia 01.12.09 provocou variação significativa nos pontos amostrados.

\subsection{ALCALINIDADE}

Os resultados da alcalinidade são apresentados na Figura 5.2.1.

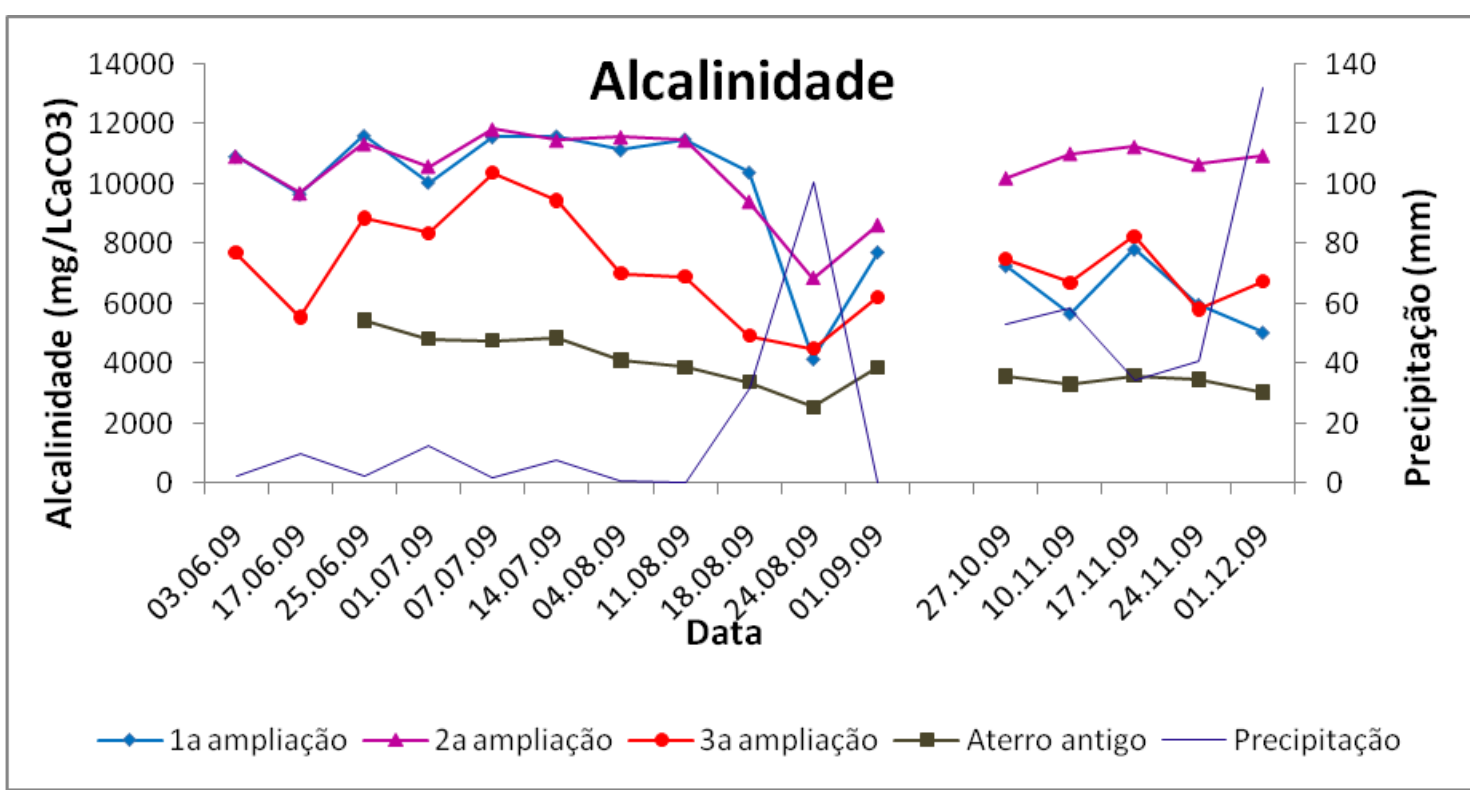

\begin{tabular}{ccccc}
\hline $\begin{array}{c}\text { Média } \\
(\mathrm{mg} / \mathrm{LCaCO} 3)\end{array}$ & $\begin{array}{c}1^{\mathrm{a}} \\
\text { ampliação }\end{array}$ & $\begin{array}{c}2^{\mathrm{a}} \\
\text { ampliação }\end{array}$ & $\begin{array}{c}3^{\mathrm{a}} \\
\text { ampliação }\end{array}$ & $\begin{array}{c}\text { Aterro } \\
\text { antigo }\end{array}$ \\
\hline \multirow{2}{*}{ Seco } & 10021 & 10328 & 7250 & 4180 \\
& $(2268)$ & $(1552)$ & $(1887)$ & $(886)$ \\
\hline \multirow{2}{*}{ Chuvoso } & 6350 & 10802 & 6997 & 3394 \\
& $(1152)$ & $(404)$ & $(916)$ & $(227)$ \\
\hline
\end{tabular}

* ( ) Desvio padrão

FIGURA 5.2.1: Comportamento da alcalinidade

Valores maiores de alcalinidade são esperados em lixiviados de aterros jovens. No período seco as $1^{\mathrm{a}}$ e $2^{\mathrm{a}}$ ampliações apresentaram valores médios de alcalinidade 
muito próximos (10021 mg/LCaCO 3 e $10328 \mathrm{mg} / \mathrm{LCaCO}_{3}$ respectivamente), enquanto a $3^{\mathrm{a}}$ ampliação resultou em um valor um pouco menor $\left(7250 \mathrm{mg} / \mathrm{L} \mathrm{CaCO}_{3}\right)$. Novamente, pode-se observar que na data 24/08/09 os valores de alcalinidade apresentaram um decréscimo nas ampliações, provavelmente devido a alta precipitação acumulada na semana anterior.

Através da figura é possível verificar que no período chuvoso a curva de alcalinidade do aterro antigo manteve-se com comportamento semelhante ao apresentado no período seco. A $2^{\mathrm{a}}$ ampliação apontou os maiores valores de alcalinidade enquanto a $1^{\mathrm{a}}$ ampliação foi o ponto que apresentou o decréscimo mais acentuado nos valores de alcalinidade. A precipitação provavelmente contribuiu na diluição do lixiviado.

\section{3 ÁCIDOS VOLÁTEIS TOTAIS - AVT}

A Figura 5.3.1 traz os resultados encontrados para ácidos voláteis totais. 


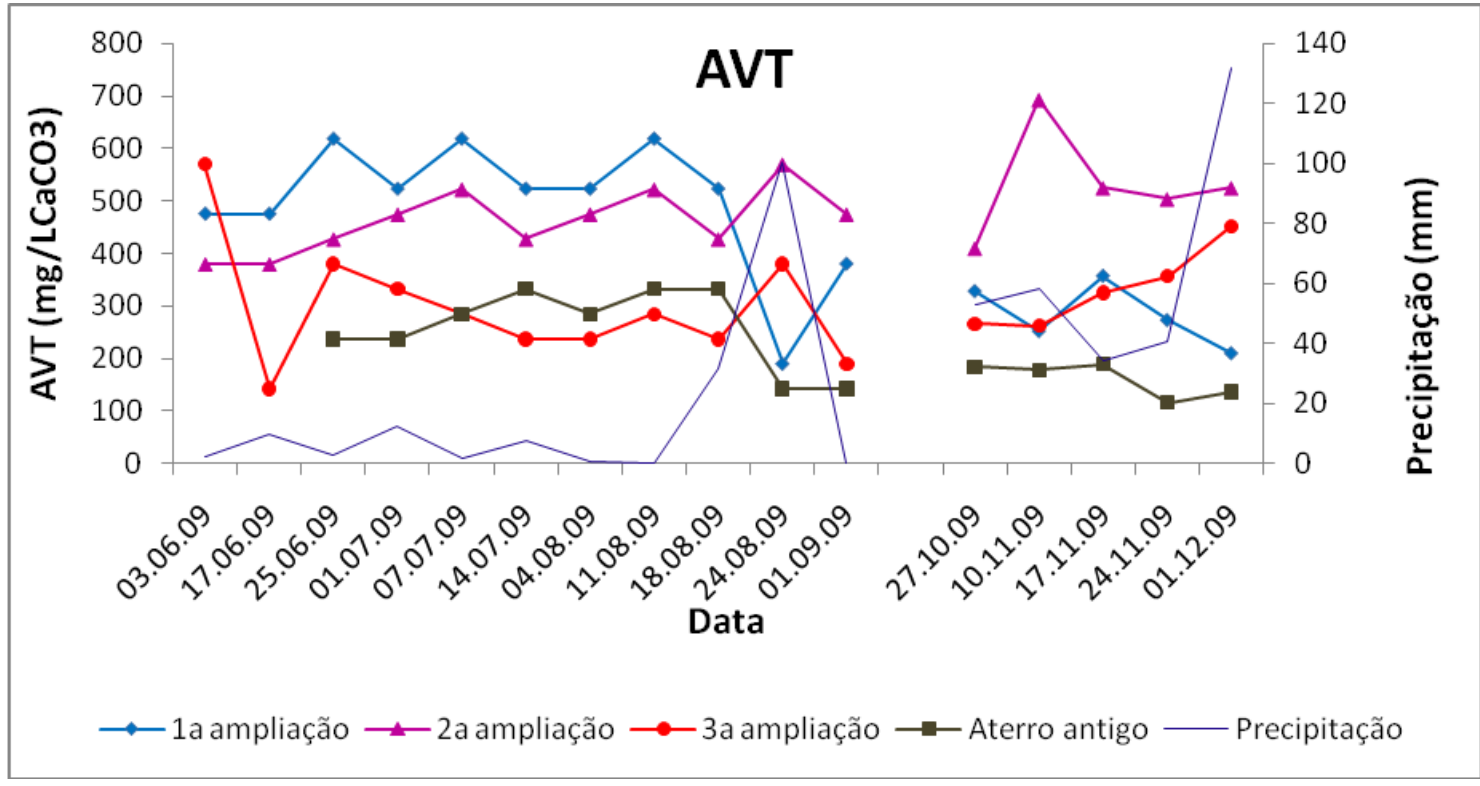

\begin{tabular}{ccccc}
\hline $\begin{array}{c}\text { Média } \\
(\mathrm{mg} / \mathrm{LCaCO} 3)\end{array}$ & $\begin{array}{c}1^{\mathrm{a}} \\
\text { ampliação }\end{array}$ & $\begin{array}{c}2^{\mathrm{a}} \\
\text { ampliação }\end{array}$ & $\begin{array}{c}3^{\mathrm{a}} \\
\text { ampliação }\end{array}$ & $\begin{array}{c}\text { Aterro } \\
\text { antigo }\end{array}$ \\
\hline Seco & $497(125)$ & $462(60)$ & $298(117)$ & $\begin{array}{c}259 \\
(76)\end{array}$ \\
\hline Chuvoso & $284(59)$ & $531(102)$ & $333(78)$ & $\begin{array}{c}161 \\
(33)\end{array}$
\end{tabular}

* ( ) Desvio padrão

FIGURA 5.3.1: Comportamento do AVT

A baixa quantidade de AVT encontrada nos lixiviados está intimamente ligada aos altos valores de pH. Quando a concentração de AVT é menor, o pH eleva-se e o sistema dióxido de carbono - bicarbonato torna-se predominante. Ao se relacionar os resultados de pH e AVT conclui-se que as células do aterro de São Carlos já se encontram na fase de fermentação metanogênica, onde o $\mathrm{pH}$ retorna à condição de tampão, controlado pelos ácidos voláteis.

No período seco, na data da maior precipitação registrada no período, a concentração de AVT na $2^{\mathrm{a}}$ e $3^{\mathrm{a}}$ ampliações aumentou, sugerindo que nestas células ainda há material há ser lixiviado.

Assim como no período seco, os valores encontrados no período chuvoso para AVT foram baixos. Como já dito na análise de AVT no período seco, CONTRERA 
(2008) sugere que estes resultados não representam necessariamente a presença de AVT no lixiviado. Estes valores podem, simplesmente, se tratar de interferência de substâncias com caráter ácido (ácido húmico, fúlvico). Seria necessária uma investigação mais profunda, através de análise de AVT na cromatografia gasosa, que comprovaria ou não a real presença destas substâncias no lixiviado.

Durante seu trabalho de doutorado CONTRERA (2008) estudou a adaptação do método de DILALLO \& ALBERTSON (1961) para o caso específico de lixiviado. A equação sugerida no trabalho tenta minimizar a interferência de substâncias de caráter ácido (ácidos húmicos, fúlvicos, fosfórico e outros) na análise de AVT.

$$
A V T_{\text {corrigido }}=1,8542 . A V T-427(5.3 .1)
$$

A Tabela 5.3.1 apresenta os valores corrigidos de AVT para o período seco.

TABELA 5.3.1: Valores corrigidos de AVT no período seco

\begin{tabular}{ccccc}
\hline Data & $\begin{array}{c}\mathbf{1}^{\mathbf{a}} \\
\text { ampliação }\end{array}$ & $\begin{array}{c}\mathbf{2}^{\mathbf{a}} \\
\text { ampliação }\end{array}$ & $\begin{array}{c}\mathbf{3}^{\text {a }} \\
\text { ampliação }\end{array}$ & $\begin{array}{c}\text { Aterro } \\
\text { Antigo }\end{array}$ \\
\hline 03.06 .09 & 454 & 278 & 630 & \\
17.06 .09 & 454 & 278 & 0 & \\
25.06 .09 & 718 & 366 & 278 & 13 \\
01.07 .09 & 542 & 454 & 190 & 13 \\
07.07 .09 & 718 & 542 & 101 & 101 \\
14.07 .09 & 542 & 366 & 13 & 190 \\
04.08 .09 & 542 & 454 & 13 & 101 \\
11.08 .09 & 718 & 542 & 101 & 190 \\
18.08 .09 & 542 & 366 & 13 & 190 \\
24.08 .09 & 0 & 630 & 278 & 0 \\
01.09 .09 & 278 & 454 & 0 & 0 \\
\hline MÉDIA & $\mathbf{4 9 4}$ & $\mathbf{4 3 0}$ & $\mathbf{1 2 5}$ & $\mathbf{5 3}$ \\
\hline
\end{tabular}


Para as $1^{\mathrm{a}}$ e $2^{\mathrm{a}}$ ampliações esta correção não alterou significantemente a média obtida. Esta correção sugerida por CONTRERA (2008) tem como finalidade mostrar que os valores de AVT encontrados no lixiviado não representam somente a presença destes ácidos, e sim a presença de várias substâncias de caráter ácido, pois o método não faz diferenciações. Sendo assim, como não houve mudanças significativas entre as médias obtidas e corrigidas, concluiu-se que não se trata da presença de AVT e sim da presença de substâncias de caráter ácido.

A Tabela 5.3.2 apresenta os valores corrigidos de AVT para o período chuvoso.

TABELA 5.3.2: Valores corrigidos de AVT no período chuvoso

\begin{tabular}{ccccc}
\hline \multirow{2}{*}{ Data } & $\begin{array}{c}\mathbf{1}^{\mathbf{a}} \\
\text { ampliação }\end{array}$ & $\begin{array}{c}\mathbf{2}^{\mathbf{a}} \\
\text { ampliação }\end{array}$ & $\begin{array}{c}\mathbf{3}^{\mathbf{a}} \\
\text { ampliação }\end{array}$ & $\begin{array}{c}\text { Aterro } \\
\text { Antigo }\end{array}$ \\
\hline 27.10 .09 & 184 & 337 & 70 & 0 \\
10.11 .09 & 43 & 865 & 62 & 0 \\
17.11 .09 & 239 & 552 & 180 & 0 \\
24.11 .09 & 82 & 513 & 239 & 0 \\
01.12 .09 & 0 & 552 & 416 & 0 \\
\hline MÉDIA & $\mathbf{1 0 2}$ & $\mathbf{5 6 4}$ & $\mathbf{1 9 3}$ & $\mathbf{0}$ \\
\hline
\end{tabular}

Esta correção também não afetou a média da $2^{a}$ ampliação. Nos demais pontos, a correção pela equação diminuiu o valor médio da concentração de AVT, sendo que no aterro antigo a concentração foi sempre zero. Mais uma vez, não se trata da presença de ácidos voláteis e sim de substâncias com caráter ácido.

\subsection{DQO}

A Figura 5.4.1 apresenta os valores de DQO. 


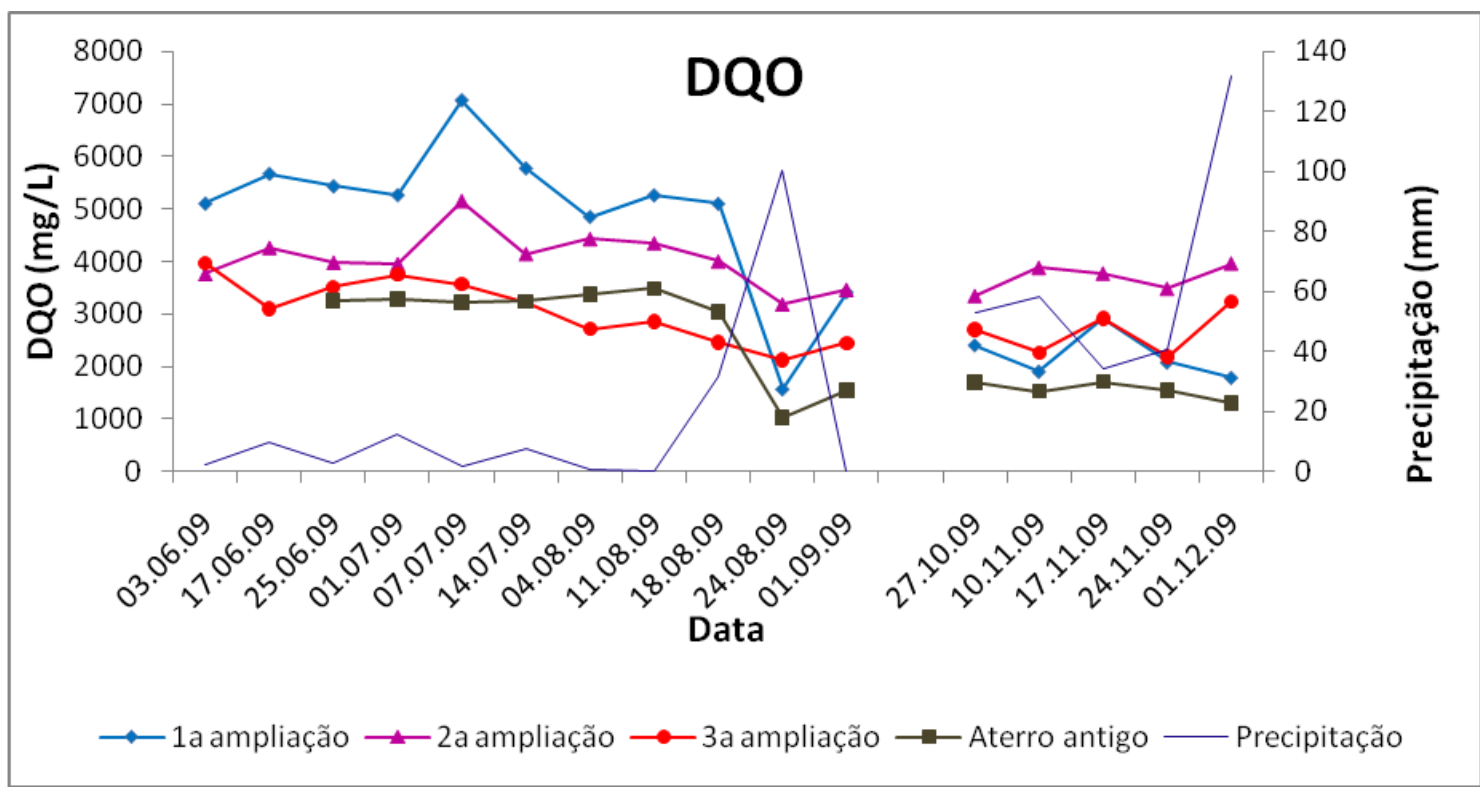

\begin{tabular}{ccccc}
\hline Média (mg/L) & $\begin{array}{c}1^{\mathrm{a}} \\
\text { ampliação }\end{array}$ & $\begin{array}{c}2^{\mathrm{a}} \\
\text { ampliação }\end{array}$ & $\begin{array}{c}3^{\mathrm{a}} \\
\text { ampliação }\end{array}$ & $\begin{array}{c}\text { Aterro } \\
\text { antigo }\end{array}$ \\
\hline \multirow{2}{*}{ Seco } & 4957 & 4067 & 3069 & 2832 \\
& $(1410)$ & $(519)$ & $(598)$ & $(891)$ \\
\hline \multirow{2}{*}{ Chuvoso } & 2221 & 3694 & 2665 & 1560 \\
& $(448)$ & $(265)$ & $(443)$ & $(166)$ \\
\hline
\end{tabular}

* ( ) Desvio padrão

FIGURA 5.4.1: Comportamento da DQO

As tabelas de composição de lixiviados mostradas no item 3.3.2 da revisão bibliográfica, apresentam faixas de valores muito amplas quando se trata de DQO. Porém, é sabido que lixiviados de aterros jovens, usualmente, apresentam altos valores de DQO, devido principalmente a grande quantidade de matéria orgânica degradável. O valor mais baixo encontrado na $3^{\mathrm{a}}$ ampliação no período seco pode ser devido a maior infiltração de chuva pois não há cobertura final, o que dilui mais o lixiviado.

Novamente na data 24/08/09, verifica-se um decréscimo nos valores de DQO, devido à alta precipitação. Este decréscimo fica mais acentuado na $1^{\mathrm{a}}$ ampliação.

Já no período chuvoso os valores de DQO sofreram decréscimo. Valores da ordem de 4000 - $5000 \mathrm{mg} / \mathrm{L}$ encontrados no período seco nas ampliações foram reduzidos a 2000 - $3000 \mathrm{mg} / \mathrm{L}$. O aterro antigo também apontou menores valores. 


\section{$5.5 \mathrm{NTK}$}

Os resultados obtidos para NTK estão na Figura 5.5.1.

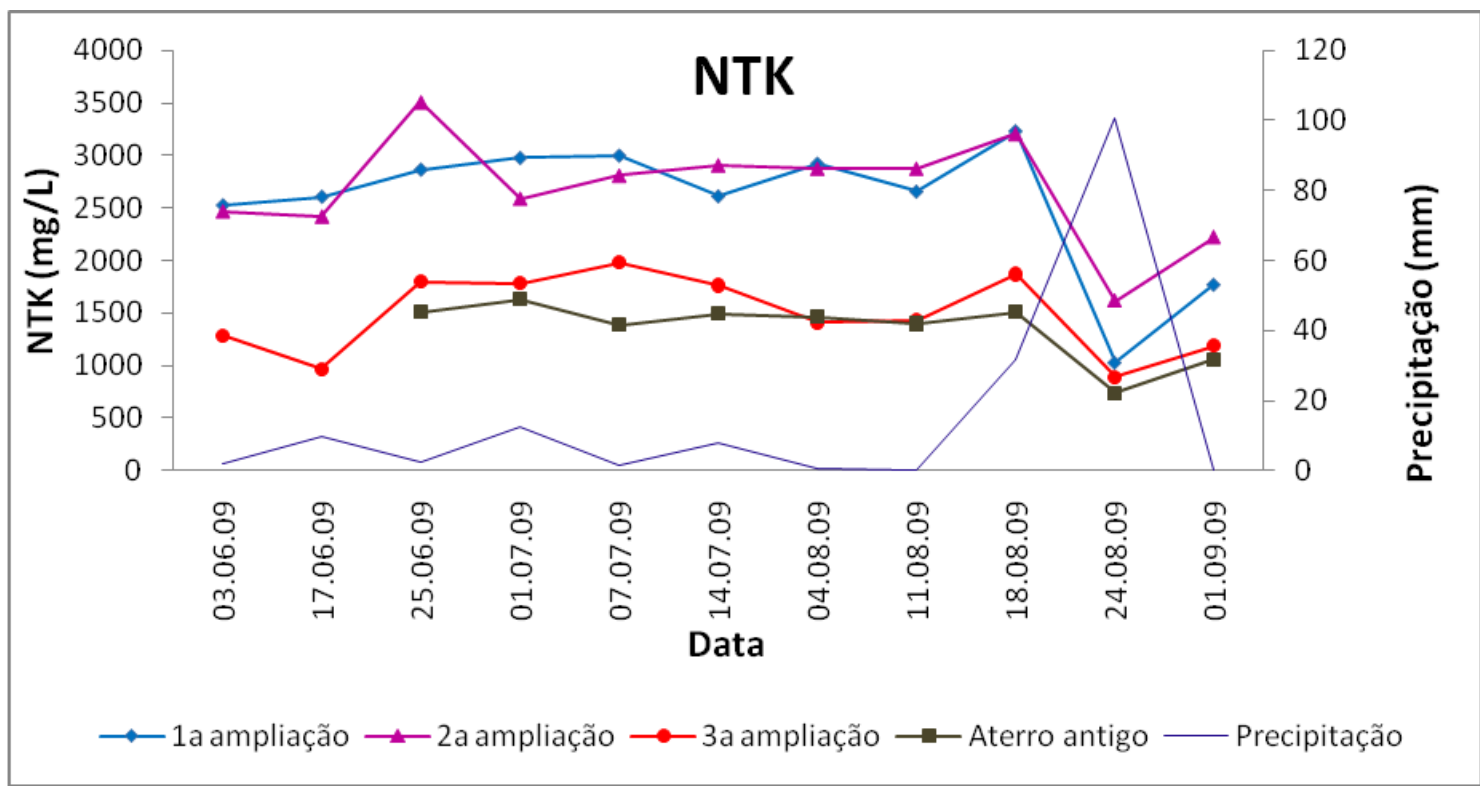

\begin{tabular}{ccccc}
\hline Média (mg/L) & $\begin{array}{c}1^{\mathrm{a}} \\
\text { ampliação }\end{array}$ & $\begin{array}{c}2^{\mathrm{a}} \\
\text { ampliação }\end{array}$ & $\begin{array}{c}3^{\mathrm{a}} \\
\text { ampliação }\end{array}$ & $\begin{array}{c}\text { Aterro } \\
\text { antigo }\end{array}$ \\
\hline \multirow{2}{*}{ Seco } & 2564 & 2683 & 1489 & 1354 \\
& $(632)$ & $(506)$ & $(377)$ & $(281)$ \\
\hline
\end{tabular}

* ( ) Desvio padrão

FIGURA 5.5.1: Comportamento do NTK

Os valores encontrados na $3^{\mathrm{a}}$ ampliação (ainda em funcionamento), estão mais próximos dos encontrados no aterro antigo (encerrado há 10 anos). Talvez, isto esteja ocorrendo porque o resíduo disposto na $3^{\mathrm{a}}$ ampliação esteja sujeito a incidência de chuva devido a falta de cobertura final desta célula do aterro.

Observa-se pela curva do aterro antigo que o NTK tende a se manter constante na falta de precipitação. Entretanto, no dia 24/08/09, após a forte precipitação, o NTK decai, devido à diluição proporcionada pela chuva. No dia 01/09/09 nota-se que o valor 
de NTK obtido ainda é menor do que aquele encontrado durante todo o período seco. Sugere-se que a precipitação ainda estava influenciando esta variável.

\subsection{N-AMONIACAL}

CONTRERA (2008) diz que existe uma relação linear entre a alcalinidade total dos lixiviados de aterros sanitários e as concentrações de $\mathrm{N}$-amoniacal, devido ao fato do $\mathrm{N}$-amoniacal estar na forma de hidrogenocarbonato de amônio (bicarbonato de amônio). Esta relação pode ser equacionada para estimativa das concentrações de Namoniacal a partir da alcalinidade total do lixiviado, quando este possuir $\mathrm{pH}$ superior a 7,0. O N-amoniacal e a alcalinidade se correlacionam muito bem, o que se justifica pelo fato de que, o N-amoniacal é o maior contribuinte para geração de alcalinidade nos lixiviados, uma vez que, quando a amônia é formada através dos processos de digestão da matéria orgânica, ela se combina com o ácido carbônico formando bicarbonato de amônio.

Como durante o período chuvoso não foi possível realizar a análise de NTK e N amoniacal, devido a problemas com o destilador de nitrogênio, optou-se por utilizar a relação entre alcalinidade e $\mathrm{N}$ amoniacal para prever possíveis resultados de $\mathrm{N}$ amoniacal. Primeiro, tentou-se obter a relação entre alcalinidade e N amoniacal para cada ponto de amostragem a partir dos dados coletados durante o período seco. Entretanto, esta maneira não se mostrou satisfatória, resultando em equações que não representavam o comportamento real entre estes parâmetros. Sendo assim, optou-se por utilizar a equação obtida por CONTRERA (2008). De acordo com o autor, esta equação pode ser aplicada somente no caso do lixiviado de São Carlos.

$$
\text { Namoniacal }=0,2456 . A l c-404,6 \text { com r }^{2}=0,952(5.6 .1)
$$


Os valores obtidos por esta equação são apresentados na Figura 5.6.1 que mostra os resultados para o $\mathrm{N}$-amoniacal.

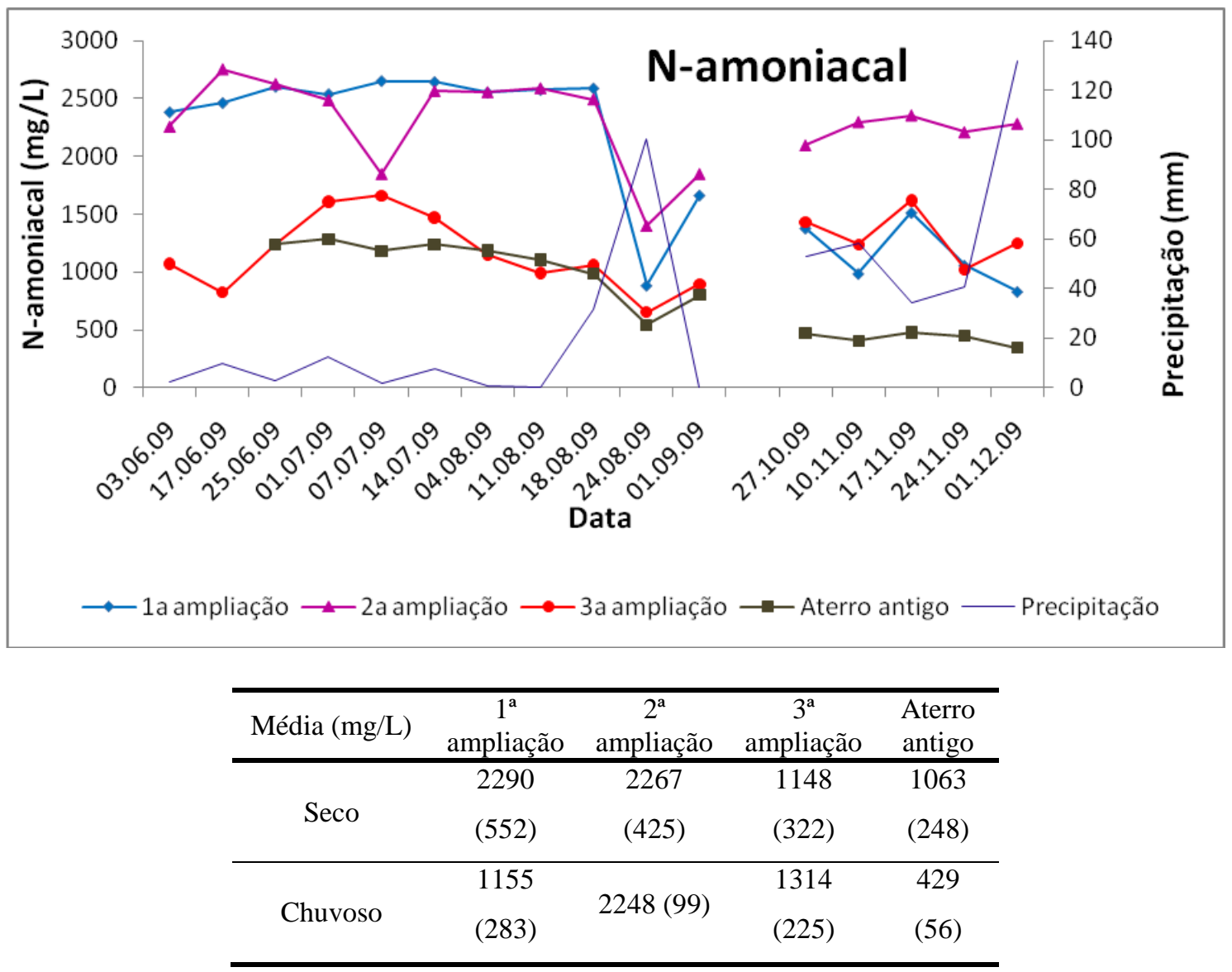

* ( ) Desvio padrão

FIGURA 5.6.1: Comportamento do N-amoniacal

Assim como o NTK, o N-amoniacal apresenta maiores concentrações nas $1^{\mathrm{a}}$ e $2^{\mathrm{a}}$ ampliações no período seco. Apesar dos valores de $\mathrm{N}$ amoniacal no período chuvoso não resultarem de análise de amostra, estes foram menores para a $1^{\mathrm{a}}$ ampliação e aterro antigo.

A Tabela 5.6.1 mostra a porcentagem do N-amoniacal em relação ao NTK e os valores de $\mathrm{N}$-orgânico calculados pela diferença entre NTK e $\mathrm{N}$-amoniacal para o período seco. 
TABELA 5.6.1: Porcentagem média do N-amoniacal em relação ao NTK e valores de N-orgânico para o período seco

\begin{tabular}{ccccc}
\hline $\begin{array}{c}\text { Ponto de } \\
\text { amostragem }\end{array}$ & NTK (mg/L) & $\begin{array}{c}\text { N-amoniacal } \\
(\mathbf{m g} / \mathbf{L})\end{array}$ & $\begin{array}{c}\text { Porcentagem } \\
\text { do N-amoniacal } \\
\text { em relação ao }\end{array}$ & $\begin{array}{c}\text { N orgânico } \\
(\mathbf{m g} / \mathbf{L})\end{array}$ \\
\hline $1^{\text {a }}$ ampliação & 2564 & 2290 & $89 \%$ & 274 \\
$2^{\text {a }}$ ampliação & 2683 & 2267 & $85 \%$ & 416 \\
$3^{\text {a } \text { ampliação }}$ & 1489 & 1148 & $77 \%$ & 341 \\
Aterro antigo & 1354 & 1063 & $79 \%$ & 291 \\
\hline
\end{tabular}

No caso específico do lixiviado, os valores do $\mathrm{N}$-amoniacal correspondem a mais de $70 \%$ do NTK. Dessa forma, fica claro que a maior parte do nitrogênio está sob a forma de amônia, constituindo um dos maiores poluentes do lixiviado.

Os valores de N-orgânico da $1^{\mathrm{a}}$ ampliação e aterro antigo foram próximos. O maior valor encontrado foi na $2^{\mathrm{a}}$ ampliação.

\subsection{SÓLIDOS TOTAIS}

A Figura 5.7.1 mostra os resultados dos sólidos. 


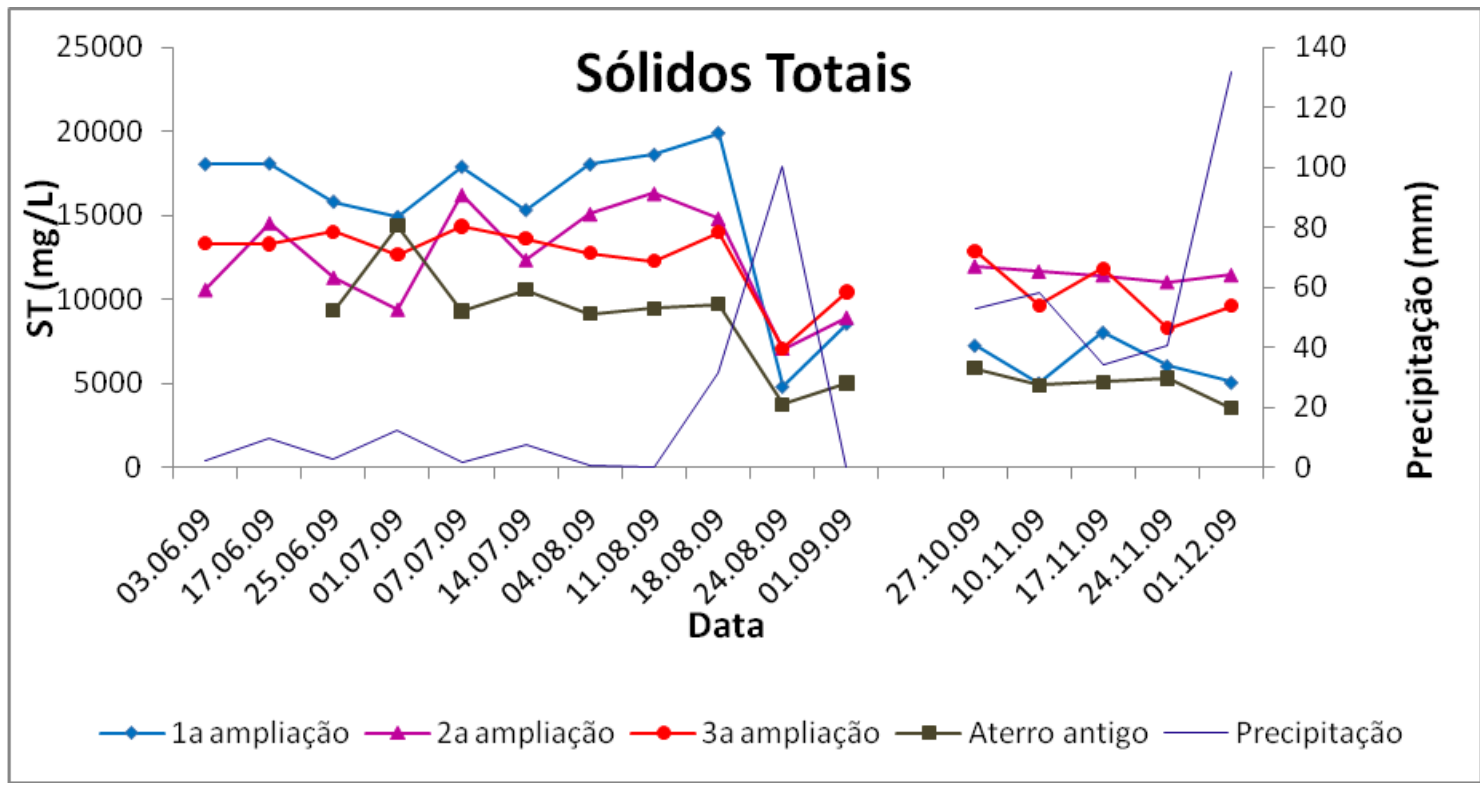

\begin{tabular}{ccccc}
\hline Média (mg/L) & $\begin{array}{c}1^{\mathrm{a}} \\
\text { ampliação }\end{array}$ & $\begin{array}{c}2^{\mathrm{a}} \\
\text { ampliação }\end{array}$ & $\begin{array}{c}3^{\mathrm{a}} \\
\text { ampliação }\end{array}$ & $\begin{array}{c}\text { Aterro } \\
\text { antigo }\end{array}$ \\
\hline \multirow{2}{*}{ Seco } & 15454 & 12424 & 12543 & 8976 \\
& $(4642)$ & $(3197)$ & $(2108)$ & $(3077)$ \\
\hline \multirow{2}{*}{ Chuvoso } & 6314 & 11521 & 10464 & 4942 \\
& $(1335)$ & $(346)$ & $(1861)$ & $(872)$ \\
\hline
\end{tabular}

* ( ) Desvio padrão

FIGURA 5.7.1: Comportamento do ST

De acordo com a Tabela 3.3.2.2 da revisão bibliográfica, nos aterros sanitários do Brasil a faixa mais provável de concentração de ST é 3200 - 14400 mg/L. No período seco as ampliações apresentaram valores maiores que esta faixa, enquanto o aterro antigo variou entre 5000 e $10000 \mathrm{mg} / \mathrm{L}$.

TCHOBANOGLOUS, THEISEN \& VIGIL (1993) afirmam que lixiviados de aterros jovens apresentam maiores concentrações de ST. O aterro antigo resultou em menor valor médio de ST quando comparado às ampliações. Pela figura verifica-se um decréscimo da concentração dos ST devido a precipitação acumulada na semana do dia 24.08.09.

Os ST não apresentaram muita variação durante o período chuvoso. Os resultados obtidos durante este período foram um pouco menores dos obtidos no 
período seco. A $1^{\mathrm{a}}$ ampliação e o aterro antigo tiveram as maiores reduções (15454 para $6314 \mathrm{mg} / \mathrm{L}$ e 8976 para $4942 \mathrm{mg} / \mathrm{L}$ ) respectivamente.

\section{SÓLIDOS TOTAIS FIXOS}

A Figura 5.7.2 traz os resultados dos sólidos totais fixos.

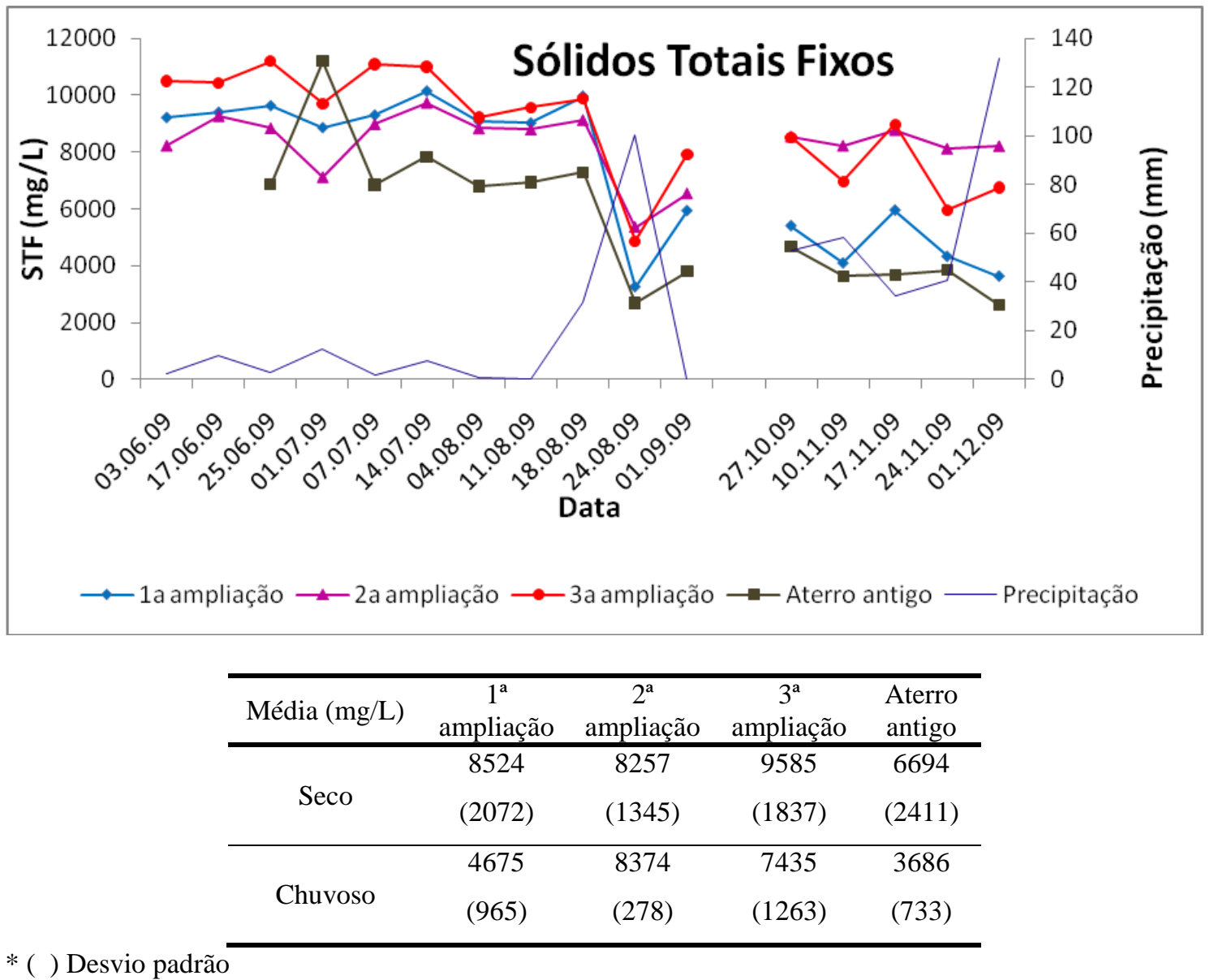

FIGURA 5.7.2: Comportamento do STF

No caso do lixiviado do aterro de São Carlos, os STF representam cerca de metade da concentração dos ST. Os lixiviados do aterro apresentaram altas concentrações de STF em todos os pontos de amostragem durante o período seco. As $1^{\mathrm{a}}$ e $2^{\mathrm{a}}$ ampliações resultaram em valores médios muito próximos $(8524$ e $8257 \mathrm{mg} / \mathrm{L}$ 
respectivamente), enquanto a $3^{a}$ ampliação teve o maior observado entre todos os pontos. Altas concentrações de STF sugerem também alta salinidade do lixiviado.

O STF foi um parâmetro que não mostrou grandes variações entre os períodos seco e chuvoso. Na época de chuvas a $2^{\mathrm{a}}$ ampliação apresentou os maiores valores enquanto o aterro antigo apresentou os menores. Além disso, o aterro antigo teve uma redução de 50\% nos valores de STF, quando comparado ao período seco.

\section{SÓLIDOS TOTAIS VOLÁTEIS}

A Figura 5.7.3 apresenta os resultados dos sólidos totais voláteis.

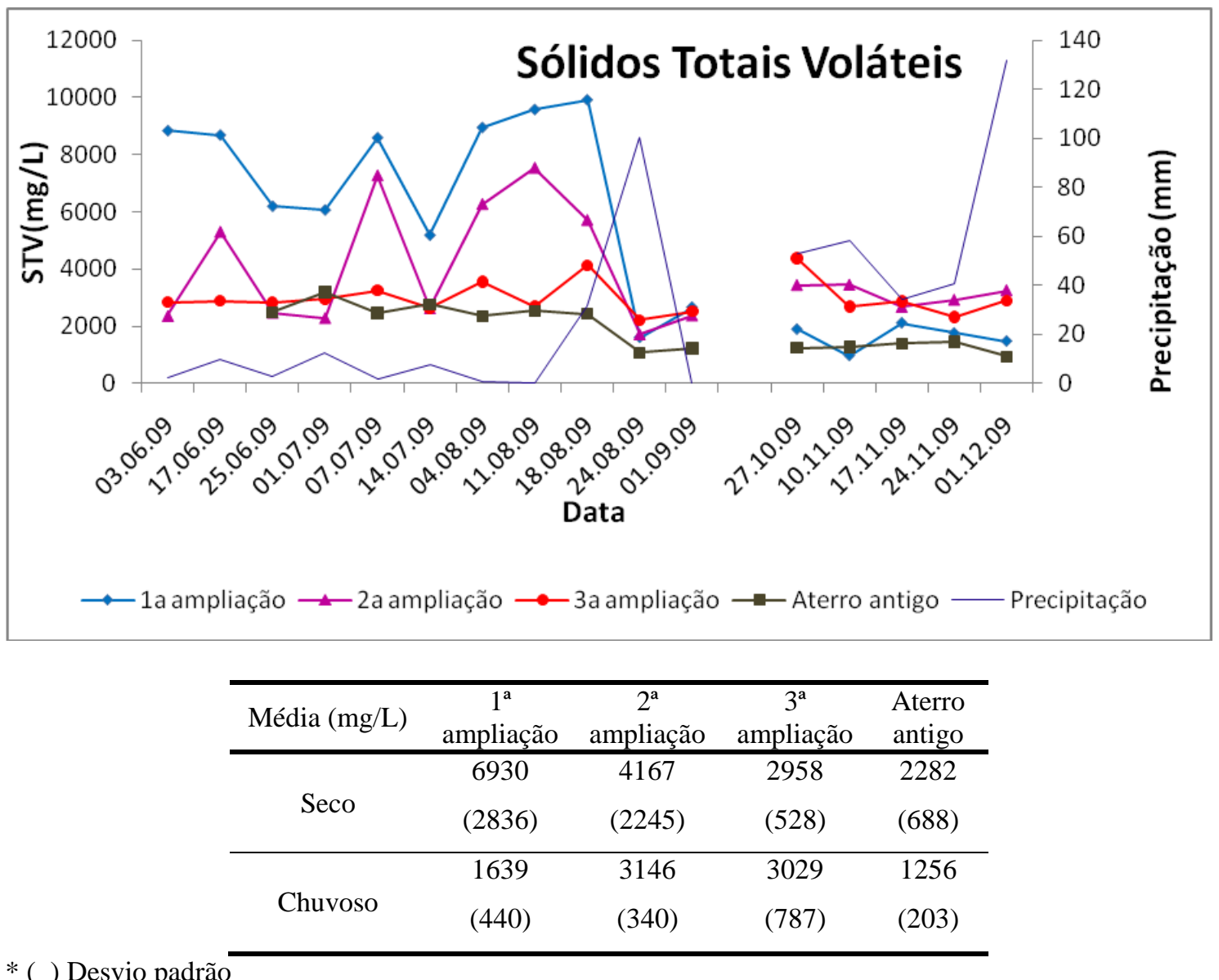

FIGURA 5.7.3: Comportamento do STV 
Elevadas concentrações de STV sugerem a altas concentrações de matéria orgânica. No período seco, mais uma vez, a precipitação ocorrida no dia 24/08/09 alterou o comportamento da variável. Pode ser verificado tanto no comportamento do ST, STF e STV que houve um decréscimo destas variáveis em todos os pontos.

Durante o período chuvoso o comportamento do STV apontou muitas variações. A $1^{a}$ ampliação resultou na maior diferença entre período seco e chuvoso - 6930 para $1639 \mathrm{mg} / \mathrm{L}$. As $2^{\mathrm{a}}$ e $3^{\mathrm{a}}$ ampliações pouco variaram entre os períodos, assim como as lagoas.

\subsection{SÓLIDOS SUSPENSOS TOTAIS}

A Figura 5.8.1 apresenta os valores de sólidos suspensos totais.

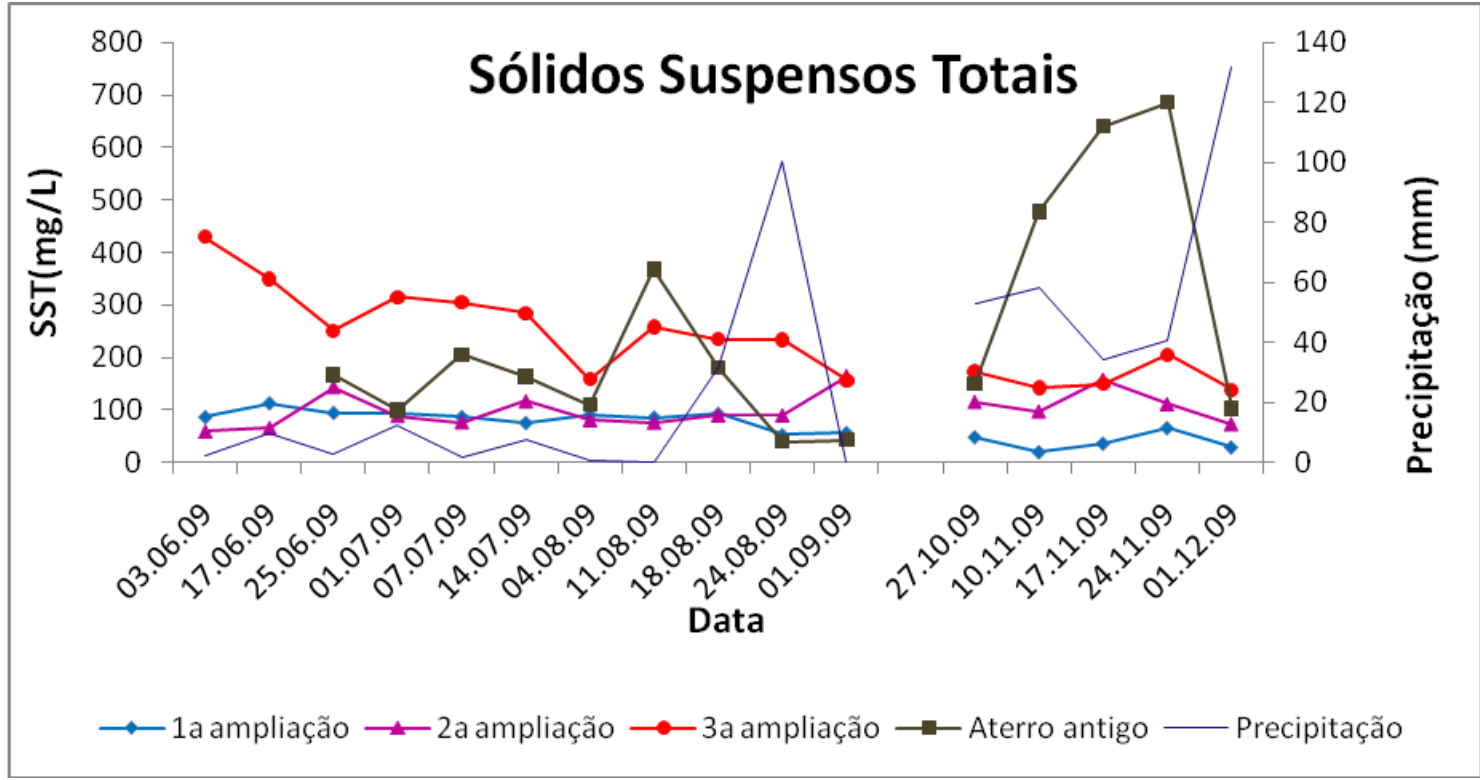

\begin{tabular}{ccccc}
\hline Média (mg/L) & $\begin{array}{c}1^{\mathrm{a}} \\
\text { ampliação }\end{array}$ & $\begin{array}{c}2^{\mathrm{a}} \\
\text { ampliação }\end{array}$ & $\begin{array}{c}3^{\mathrm{a}} \\
\text { ampliação }\end{array}$ & $\begin{array}{c}\text { Aterro } \\
\text { antigo }\end{array}$ \\
\hline Seco & $85(17)$ & $96(33)$ & $271(80)$ & $\begin{array}{c}153 \\
(100)\end{array}$ \\
\hline Chuvoso & $41(18)$ & $111(31)$ & $162(28)$ & $\begin{array}{c}411 \\
(272)\end{array}$ \\
\hline
\end{tabular}

* ( ) Desvio padrão 
No período seco o maior valor médio de SST foi encontrado na $3^{\mathrm{a}}$ ampliação, porém ainda foi um valor relativamente baixo, sugerindo que todo o lixiviado gerado no aterro encontra-se na fase metanogênica de degradação da matéria orgânica. A precipitação de 24/08/09 influenciou o comportamento do SST do aterro antigo.

$\mathrm{Na}$ época de chuvas, enquanto todos os pontos de coleta mostraram valores menores que $200 \mathrm{mg} / \mathrm{L}$, o aterro antigo apontou alguns valores superiores a $600 \mathrm{mg} / \mathrm{L}$. Isto pode ser devido a dificuldade de coleta neste ponto (o que pode ter contaminado a amostra com sólidos).

\section{SÓLIDOS SUSPENSOS FIXOS}

A Figura 5.8.2 mostra os resultados dos sólidos suspensos fixos.

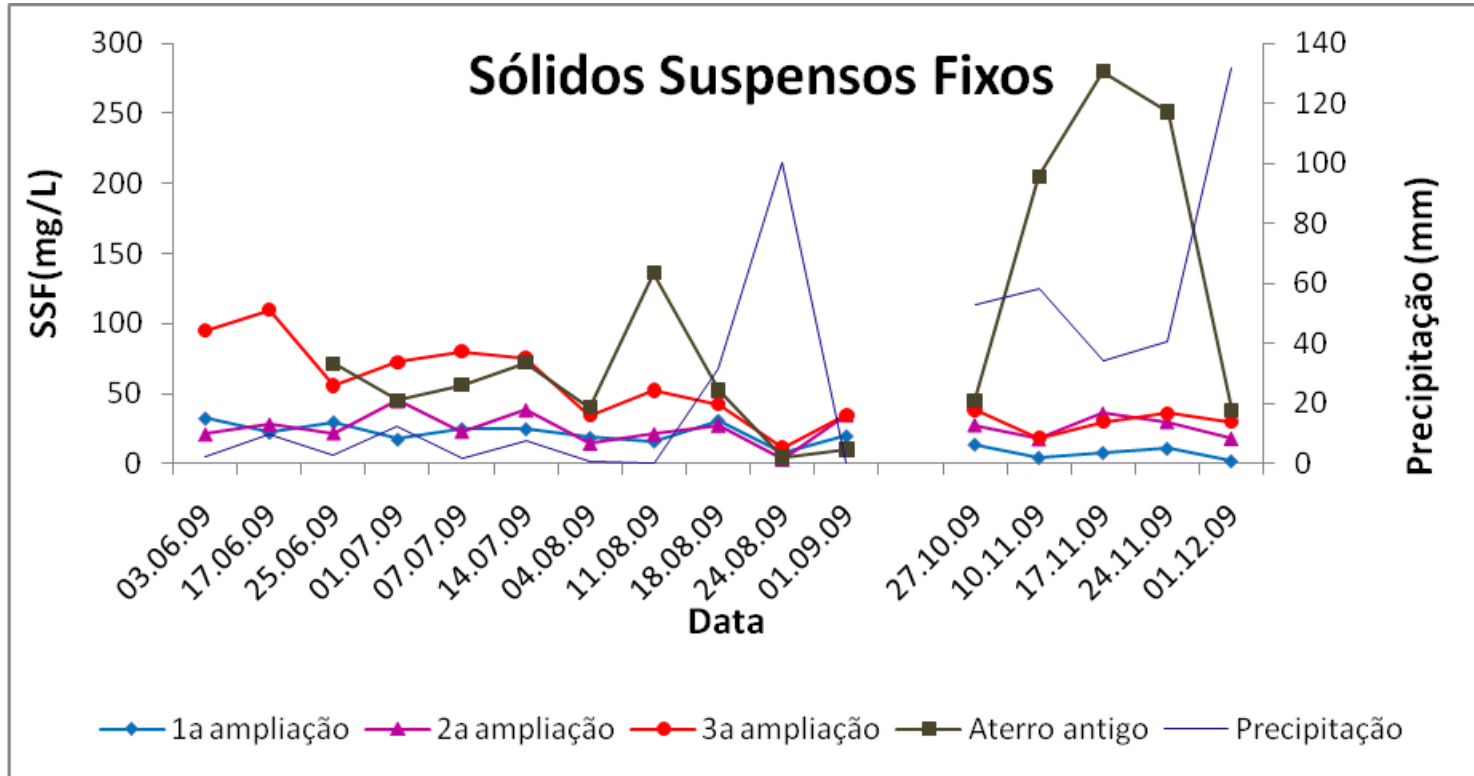

\begin{tabular}{ccccc}
\hline Média (mg/L) & $\begin{array}{c}1^{\mathrm{a}} \\
\text { ampliação }\end{array}$ & $\begin{array}{c}2^{\mathrm{a}} \\
\text { ampliação }\end{array}$ & $\begin{array}{c}3^{\mathrm{a}} \\
\text { ampliação }\end{array}$ & $\begin{array}{c}\text { Aterro } \\
\text { antigo }\end{array}$ \\
\hline Seco & $22(7)$ & $25(12)$ & $60(29)$ & $54(39)$ \\
\hline Chuvoso & $8(5)$ & $26(8)$ & $31(8)$ & 164 \\
\end{tabular}

* ( ) Desvio padrão

FIGURA 5.8.2: Comportamento do SSF 
Assim como ocorreu no comportamento do SST, o SSF também variou bastante durante o período de seca, exceto pela $1^{\mathrm{a}}$ ampliação, que apresentou comportamento mais constante. A precipitação de 24/08/09 afetou profundamente todos os pontos.

$\mathrm{Na}$ época de chuvas a presença de SSF foi menor que a observada no período seco. Novamente os maiores valores foram obtidos no aterro antigo, provavelmente por causa de contaminação da amostra.

\section{SÓLIDOS SUSPENSOS VOLÁTEIS}

Os resultados obtidos de sólidos suspensos voláteis estão na Figura 5.8.3.

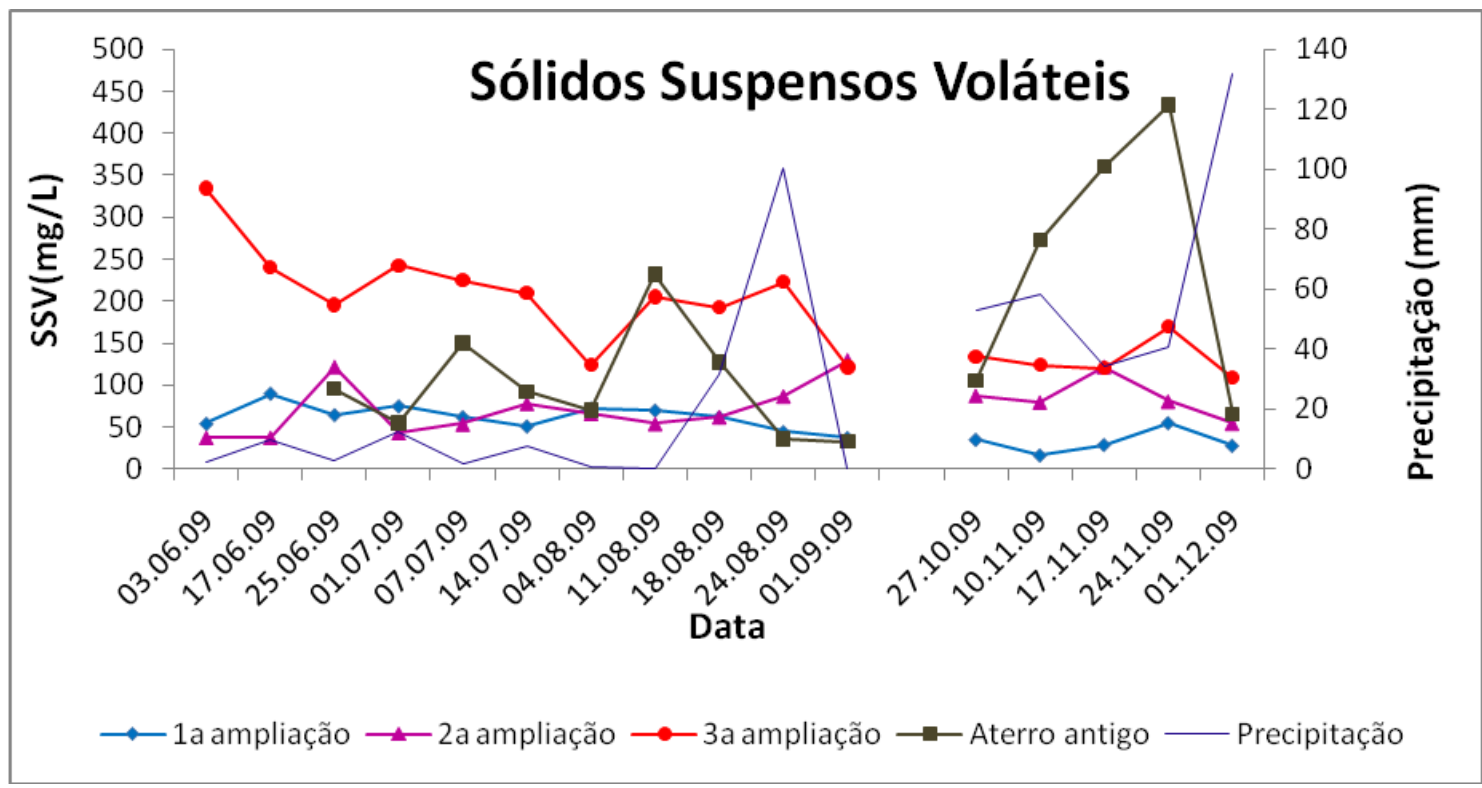

\begin{tabular}{ccccc}
\hline Média (mg/L) & $\begin{array}{c}1^{\mathrm{a}} \\
\text { ampliação }\end{array}$ & $\begin{array}{c}2^{\mathrm{a}} \\
\text { ampliação }\end{array}$ & $\begin{array}{c}3^{\mathrm{a}} \\
\text { ampliação }\end{array}$ & $\begin{array}{c}\text { Aterro } \\
\text { antigo }\end{array}$ \\
\hline Seco & $62(15)$ & $70(32)$ & $210(58)$ & $99(64)$ \\
\hline Chuvoso & $33(14)$ & $85(24)$ & $132(23)$ & $\begin{array}{c}247 \\
(159)\end{array}$
\end{tabular}

* ( ) Desvio padrão

FIGURA 5.8.3: Comportamento do SSV 
A maior parte dos SST encontra-se na forma de SSV. Novamente, exceto pela $1^{\mathrm{a}}$ ampliação, o SSV apresentou uma grande variação durante o período seco.

Em comparação ao período seco, o aterro antigo teve maiores concentrações, enquanto os outros pontos mantiveram o comportamento observado antes.

\subsection{METAIS}

\section{Chumbo - Pb}

A Figura 5.9.1 apresenta os resultados encontrados para o chumbo.

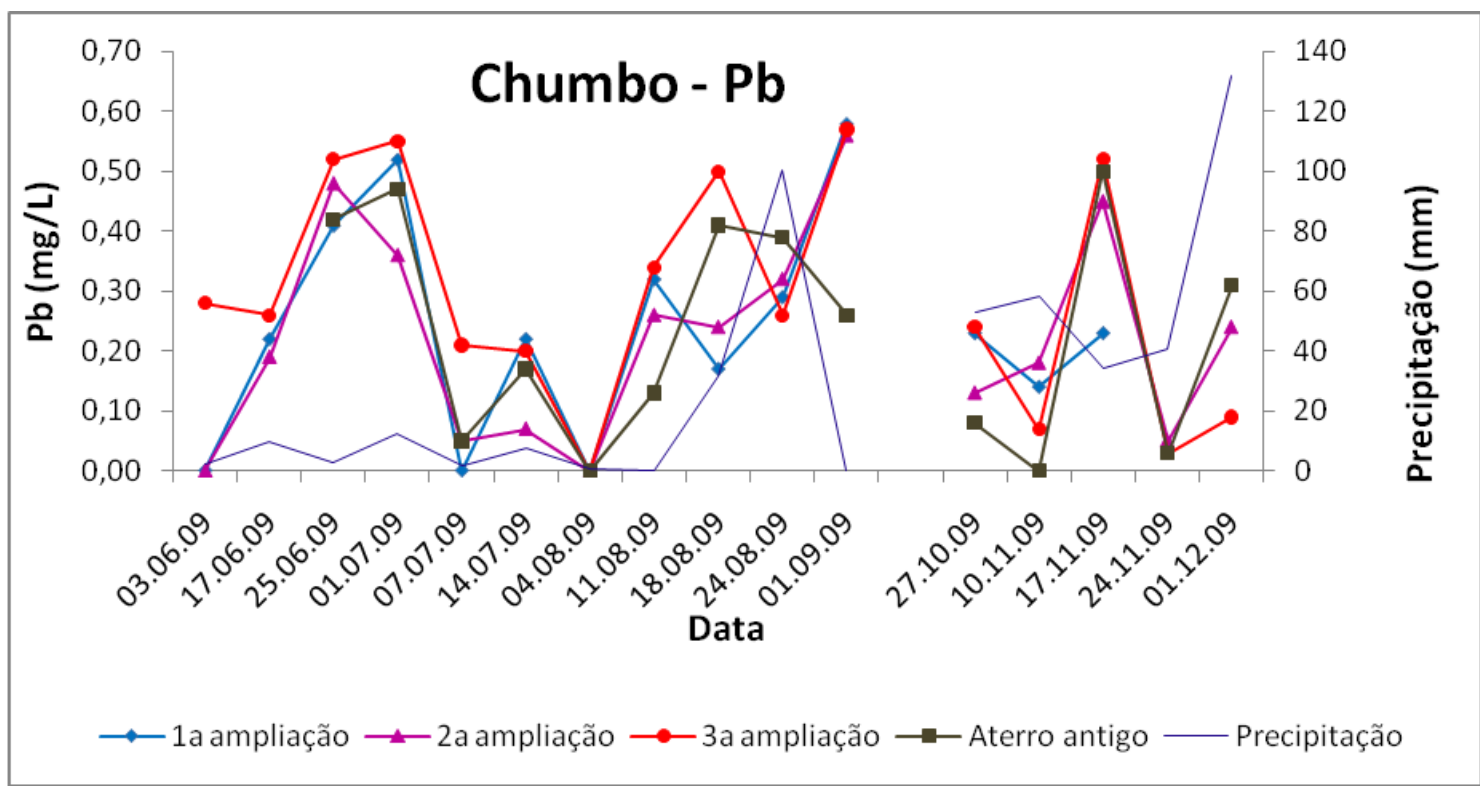

\begin{tabular}{ccccc}
\hline Média (mg/L) & $\begin{array}{c}1^{\mathrm{a}} \\
\text { ampliação }\end{array}$ & $\begin{array}{c}2^{\mathrm{a}} \\
\text { ampliação }\end{array}$ & $\begin{array}{c}3^{\mathrm{a}} \\
\text { ampliação }\end{array}$ & $\begin{array}{c}\text { Aterro } \\
\text { antigo }\end{array}$ \\
\hline \multirow{2}{*}{ Seco } & 0,25 & 0,23 & 0,34 & 0,26 \\
& $(0,20)$ & $(0,19)$ & $(0,18)$ & $(0,18)$ \\
\hline \multirow{2}{*}{ Chuvoso } & 0,20 & 0,21 & 0,19 & 0,18 \\
& $(0,05)$ & $(0,15)$ & $(0,20)$ & $(0,21)$ \\
\hline
\end{tabular}

* ( ) Desvio padrão

FIGURA 5.9.1: Comportamento do chumbo 
De acordo com a CONAMA 357/05 o limite máximo de concentração de chumbo em efluentes para lançamento em corpos d'água é $0,5 \mathrm{mg} / \mathrm{L}$. Tanto no período seco como no chuvoso, a média encontrada foi menor que o valor estabelecido pela norma.

Durante o período seco a maior concentração foi encontrada na $3^{\mathrm{a}}$ ampliação e no período chuvoso foi encontrada na $2^{\mathrm{a}}$ ampliação. Pela figura não é possível estabelecer relação entre precipitação acumulada e concentração de chumbo.

\section{Cádmio - Cd}

O comportamento do cádmio observado no aterro é mostrado na Figura 5.9.3.

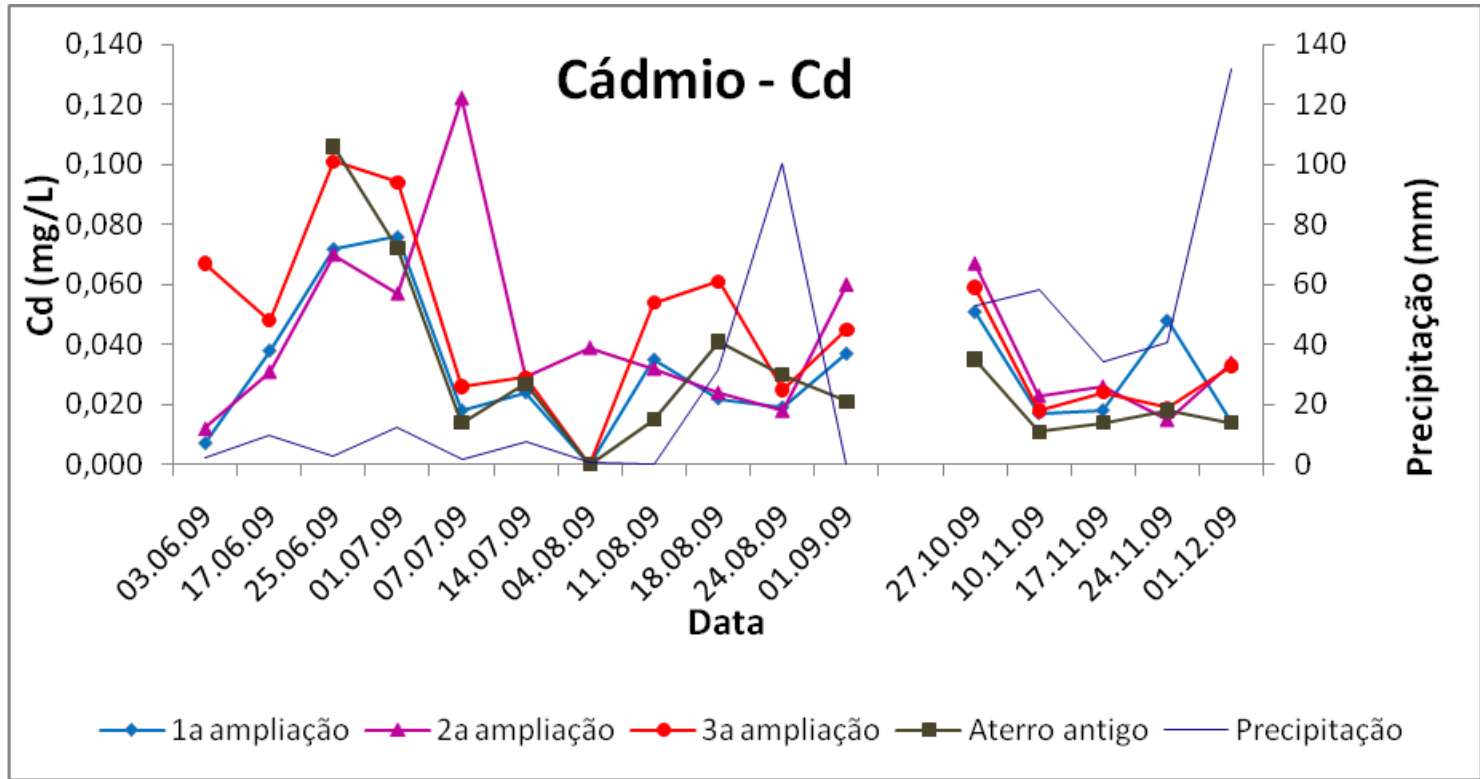

\begin{tabular}{ccccc}
\hline Média (mg/L) & $\begin{array}{c}1^{\mathrm{a}} \\
\text { ampliação }\end{array}$ & $\begin{array}{c}2^{\mathrm{a}} \\
\text { ampliação }\end{array}$ & $\begin{array}{c}3^{\mathrm{a}} \\
\text { ampliação }\end{array}$ & $\begin{array}{c}\text { Aterro } \\
\text { antigo }\end{array}$ \\
\hline \multirow{2}{*}{ Seco } & 0,032 & 0,045 & 0,050 & 0,036 \\
& $(0,024)$ & $(0,031)$ & $(0,030)$ & $(0,033)$ \\
\hline \multirow{2}{*}{ Chuvoso } & 0,030 & 0,033 & 0,031 & 0,018 \\
& $(0,018)$ & $(0,020)$ & $(0,017)$ & $(0,010)$ \\
\hline
\end{tabular}

* ( ) Desvio padrão

FIGURA 5.9.3: Comportamento do cádmio 
Através da Figura fica evidenciada a baixa concentração desse metal encontrado no lixiviado, ao se comparar ao máximo permitido pela CONAMA 357/05. A maior média encontrada foi $0,050 \mathrm{mg} / \mathrm{L}$ na $3^{\mathrm{a}}$ ampliação enquanto o limite é de $0,2 \mathrm{mg} / \mathrm{L}$.

A precipitação parece influenciar a concentração deste metal na solução. Nas coletas do dia 24.08.09 e 10.11.09 houve aumento da precipitação e conseqüente diminuição da concentração de cádmio.

\section{Níquel - Ni}

A Figura 5.9.3 mostra os resultados obtidos para o níquel.

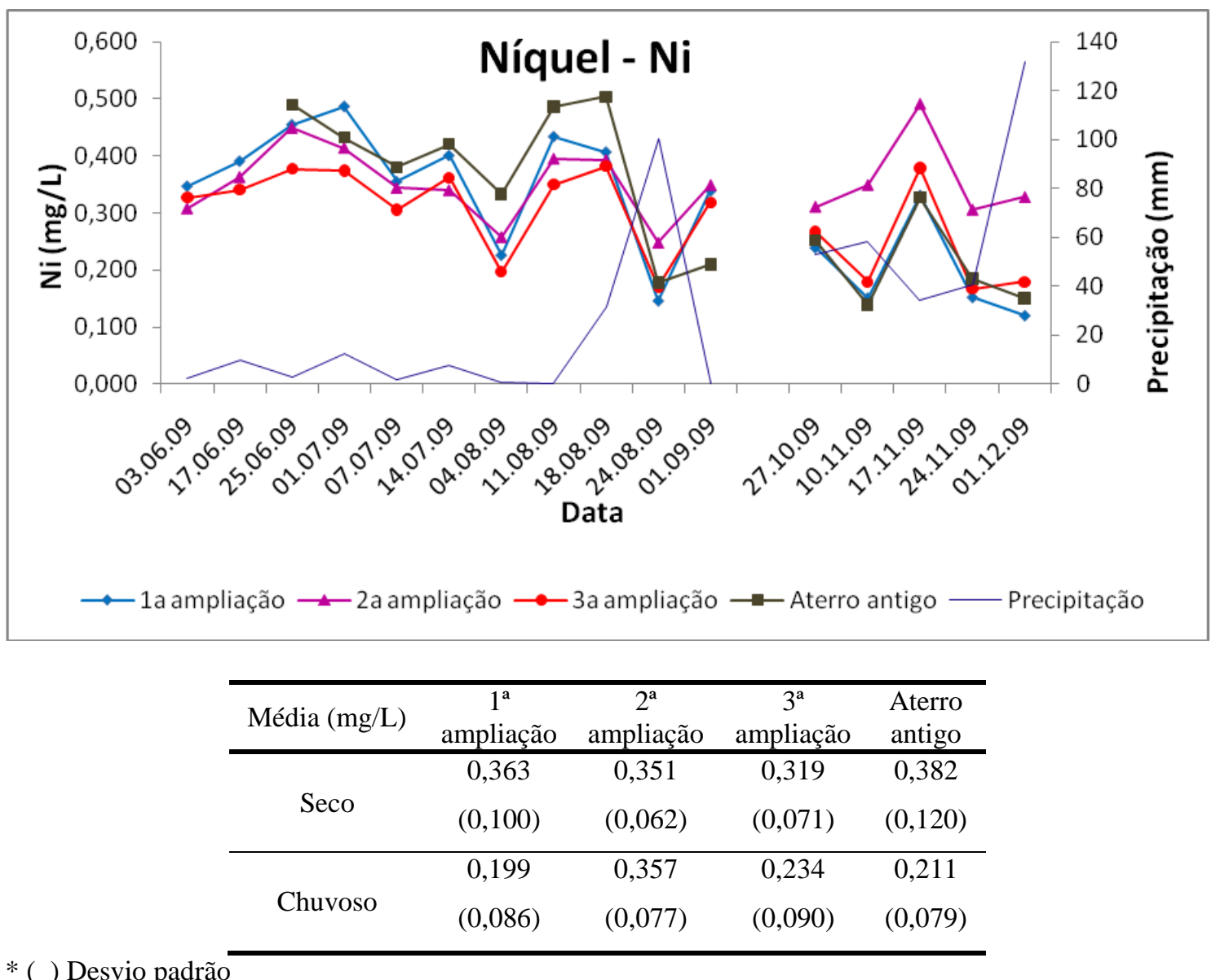

FIGURA 5.9.3: Comportamento do níquel 
Em nenhum ponto foi detectado valores de concentração de níquel superiores a 2,0 mg/L, que é o limite máximo tolerado para lançamento de efluentes em corpos d’água de acordo com a CONAMA 357/05.

No período seco todas as concentrações médias de níquel se apresentaram entre 0,300 e 0,400 mg/L. Os valores médios encontrados no período chuvoso são ligeiramente menores que os obtidos no período seco. A faixa de variação dos valores médios foi $0,199 \mathrm{mg} / \mathrm{L}$ a $0,357 \mathrm{mg} / \mathrm{L}$.

\section{Ferro - Fe}

Os valores encontrados para o ferro estão na Figura 5.9.4.

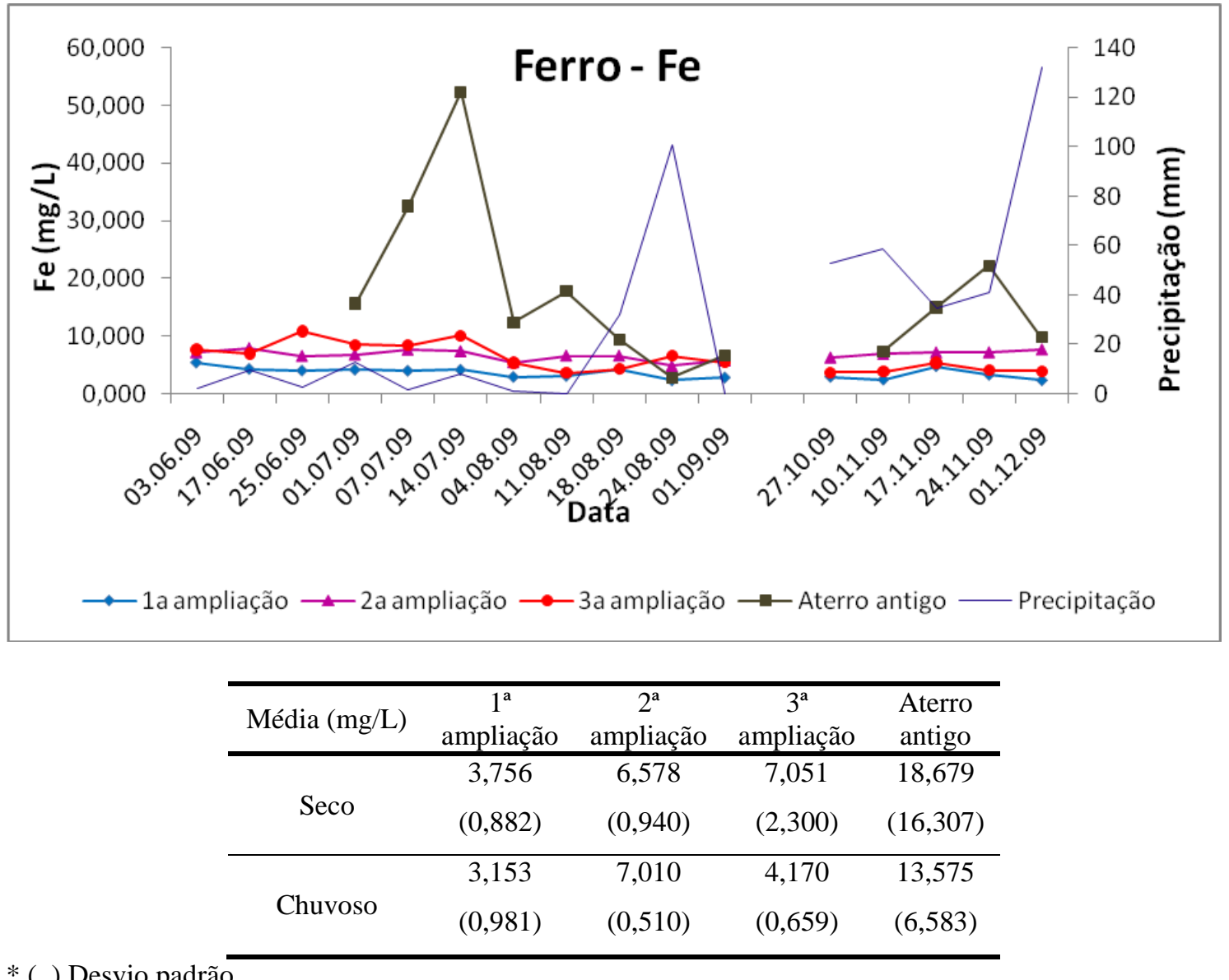

FIGURA 5.9.4: Comportamento do ferro 
Todos os pontos de amostragem mostram que a concentração de ferro não varia muito ao longo do tempo. No dia 25/06/09 o aterro antigo resultou numa concentração de ferro de 146,600 mg/L. Entendeu-se que este resultado pode ter sido superestimado devido as condições de coleta (pouca vazão, grande quantidade de sólidos na caixa de passagem e coletor inadequado). Nesta coleta a amostra pode ter sido contaminada por grande quantidade de sólidos provenientes do solo e sabe-se que o solo utilizado na cobertura do aterro é rico em ferro. Sendo assim, optou-se por excluir este ponto do gráfico. A maior concentração é verifica no aterro antigo.

Durante o período chuvoso o ferro manteve comportamento semelhante ao observado no período de seca. Apesar da análise de ferro ter sido feita a partir do sobrenadante do lixiviado, a coleta do aterro antigo sempre foi muito prejudicada devido ao difícil acesso à caixa de passagem e a grande quantidade de solo presente no ponto de coleta.

A Resolução CONAMA estabelece que o limite máximo para o ferro é de 15 $\mathrm{mg} / \mathrm{L}$. Exceto pelo aterro antigo, todos os pontos atendem a essa norma.

\section{$>$ Cobre $-\mathrm{Cu}$}

A Figura 5.9.5 apresenta os resultados para o cobre. 


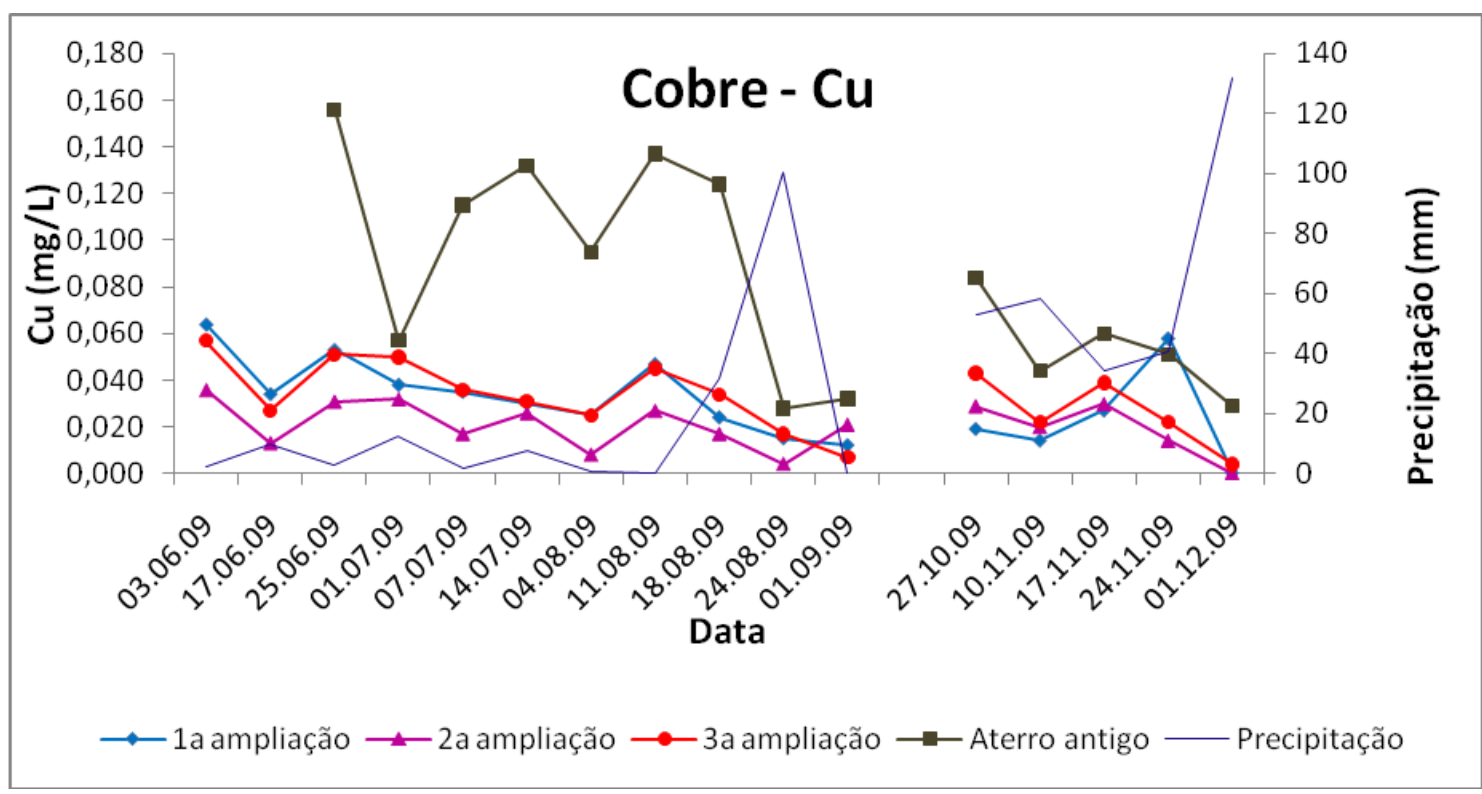

\begin{tabular}{ccccc}
\hline Média (mg/L) & $\begin{array}{c}1^{\mathrm{a}} \\
\text { ampliação }\end{array}$ & $\begin{array}{c}2^{\mathrm{a}} \\
\text { ampliação }\end{array}$ & $\begin{array}{c}3^{\mathrm{a}} \\
\text { ampliação }\end{array}$ & $\begin{array}{c}\text { Aterro } \\
\text { antigo }\end{array}$ \\
\hline \multirow{2}{*}{ Seco } & 0,034 & 0,021 & 0,035 & 0,097 \\
& $(0,016)$ & $(0,010)$ & $(0,015)$ & $(0,047)$ \\
\hline \multirow{2}{*}{ Chuvoso } & 0,024 & 0,019 & 0,026 & 0,054 \\
& $(0,022)$ & $(0,012)$ & $(0,016)$ & $(0,020)$ \\
\hline
\end{tabular}

* ( ) Desvio padrão

FIGURA 5.9.5: Comportamento do cobre

No caso do aterro sanitário de São Carlos, todas as concentrações observadas de cobre foram menores que as estabelecidas pela legislação, ou seja, 1,0 mg/L. Estes baixos valores de cobre apresentados podem estar ligados as características dos resíduos aterrados, tipo de solo do local, entre outros.

Enquanto no período seco todas as concentrações observadas foram menores que 0,200 mg/L, no período chuvoso este valor decaiu para 0,100 mg/L. As maiores médias encontradas deste metal foram 0,097 e $0,054 \mathrm{mg} / \mathrm{L}$ no aterro antigo.

\section{Cromo - Cr}

A Figura 5.9.6 traz o comportamento deste metal. 


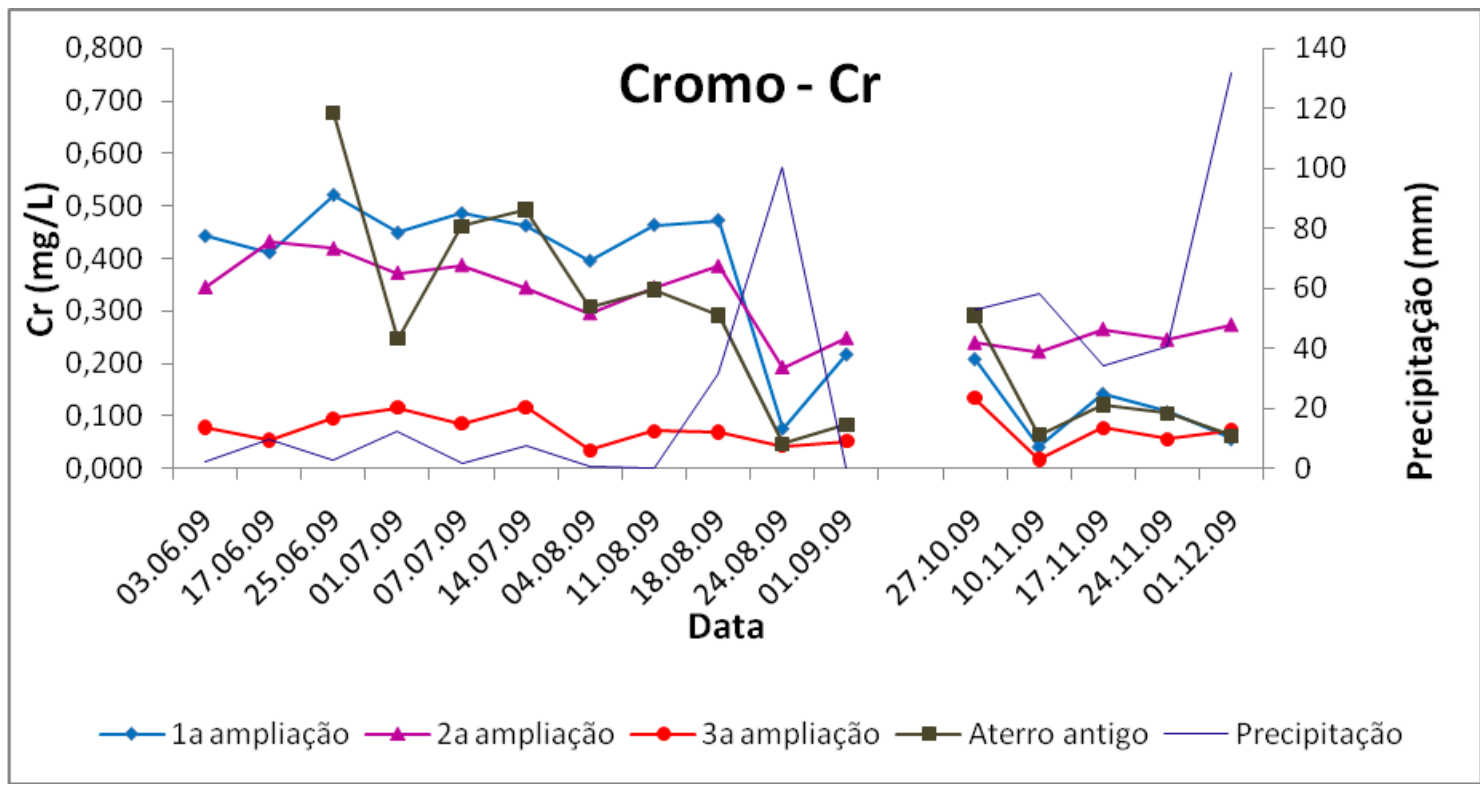

\begin{tabular}{ccccc}
\hline Média $(\mathrm{mg} / \mathrm{L})$ & $\begin{array}{c}1^{\mathrm{a}} \\
\text { ampliação }\end{array}$ & $\begin{array}{c}2^{\mathrm{a}} \\
\text { ampliação }\end{array}$ & $\begin{array}{c}3^{\mathrm{a}} \\
\text { ampliação }\end{array}$ & $\begin{array}{c}\text { Aterro } \\
\text { antigo }\end{array}$ \\
\hline \multirow{2}{*}{ Seco } & 0,400 & 0,342 & 0,075 & 0,328 \\
& $(0,133)$ & $(0,072)$ & $(0,028)$ & $(0,198)$ \\
\hline \multirow{2}{*}{ Chuvoso } & 0,112 & 0,249 & 0,072 & 0,129 \\
& $(0,068)$ & $(0,020)$ & $(0,042)$ & $(0,095)$ \\
\hline
\end{tabular}

* ( ) Desvio padrão

FIGURA 5.9.6: Comportamento do cromo

A legislação estabelece $0,5 \mathrm{mg} / \mathrm{L}$ de concentração de cromo como limite máximo para que o efluente possa ser encaminhado a um corpo d’água. A $1^{a}$ ampliação e o aterro antigo apresentaram alguns valores próximos ou superiores a este durante o período de seca. Todos os outros pontos resultaram valores inferiores ao estabelecido pela norma.

\section{Sódio - Na}

A Figura 5.9.7 apresenta o comportamento do sódio. 


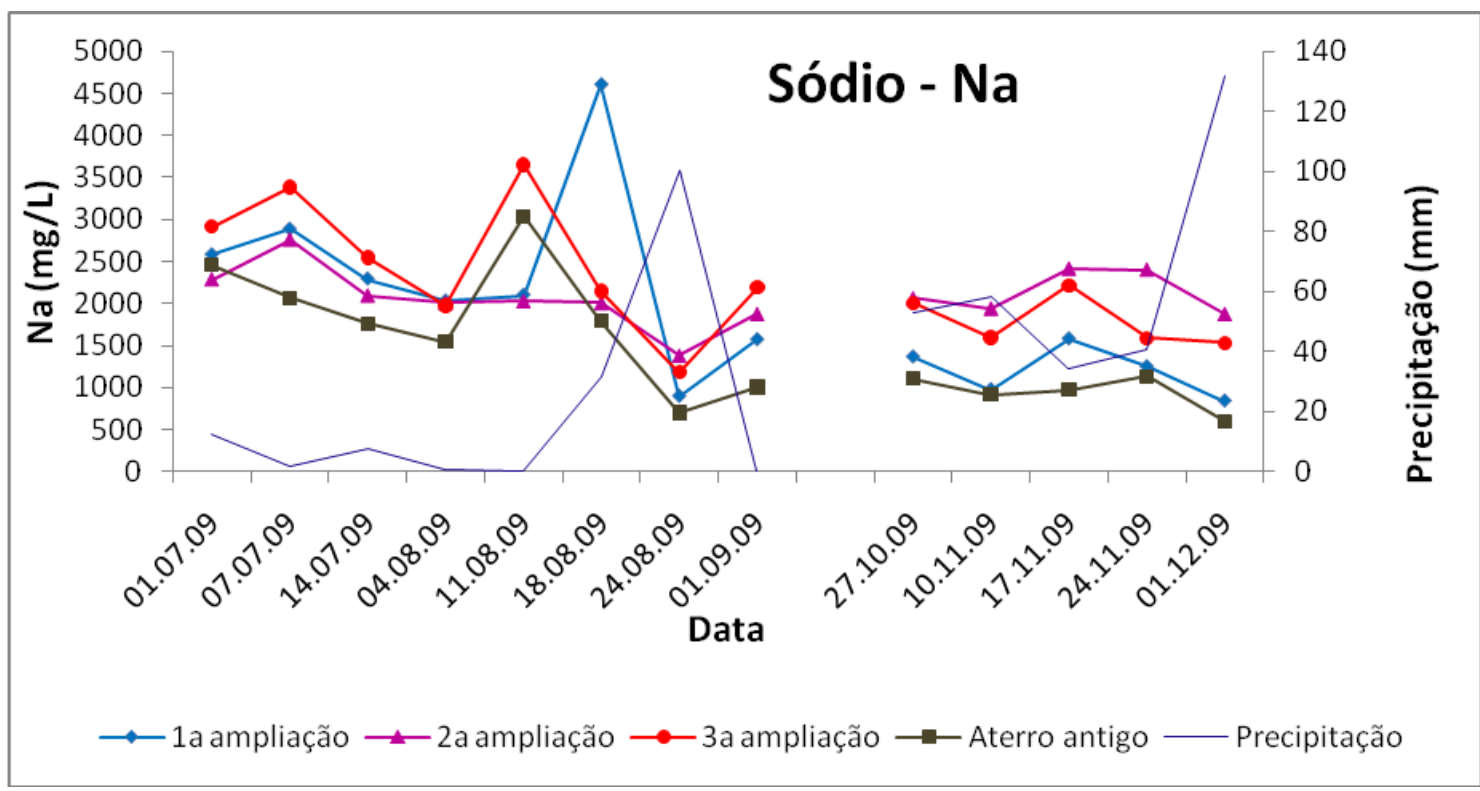

\begin{tabular}{ccccc}
\hline Média (mg/L) & $\begin{array}{c}1^{\mathrm{a}} \\
\text { ampliação }\end{array}$ & $\begin{array}{c}2^{\mathrm{a}} \\
\text { ampliação }\end{array}$ & $\begin{array}{c}3^{\mathrm{a}} \\
\text { ampliação }\end{array}$ & $\begin{array}{c}\text { Aterro } \\
\text { antigo }\end{array}$ \\
\hline \multirow{2}{*}{ Seco } & 2368 & 2057 & 2499 & 1796 \\
& $(1089)$ & $(387)$ & $(804)$ & $(750)$ \\
\hline \multirow{2}{*}{ Chuvoso } & 1200 & 2141 & 1788 & 947 \\
& $(298)$ & $(255)$ & $(305)$ & $(215)$ \\
\hline
\end{tabular}

* ( ) Desvio padrão

FIGURA 5.9.7: Comportamento do sódio

No dia 11/08/09 houve um aumento da concentração de sódio em praticamente todos os pontos, exceto nas $1^{\mathrm{a}}$ e $2^{\mathrm{a}}$ ampliações. Entretanto pela curva de precipitação verifica-se que não houve registro de nenhuma chuva ou qualquer outro evento que pudesse justificar esse acréscimo. Mais uma vez no dia 24/08/09 houve decréscimo nos valores devido à chuva ocorrida. Os valores de sódio ficaram muito próximos nas $1^{\mathrm{a}}$ e $3^{\mathrm{a}}$ ampliações.

Já durante o período chuvoso o comportamento do sódio sofreu menos perturbações que durante o período seco. Um ligeiro aumento na concentração pode ser verificado no dia 17/11/09. As maiores concentrações foram observadas na $2^{\text {a }}$ ampliação, enquanto que as menores estão no aterro antigo. 
Potássio - K

O comportamento do potássio pode ser visualizado na Figura 5.9.8.

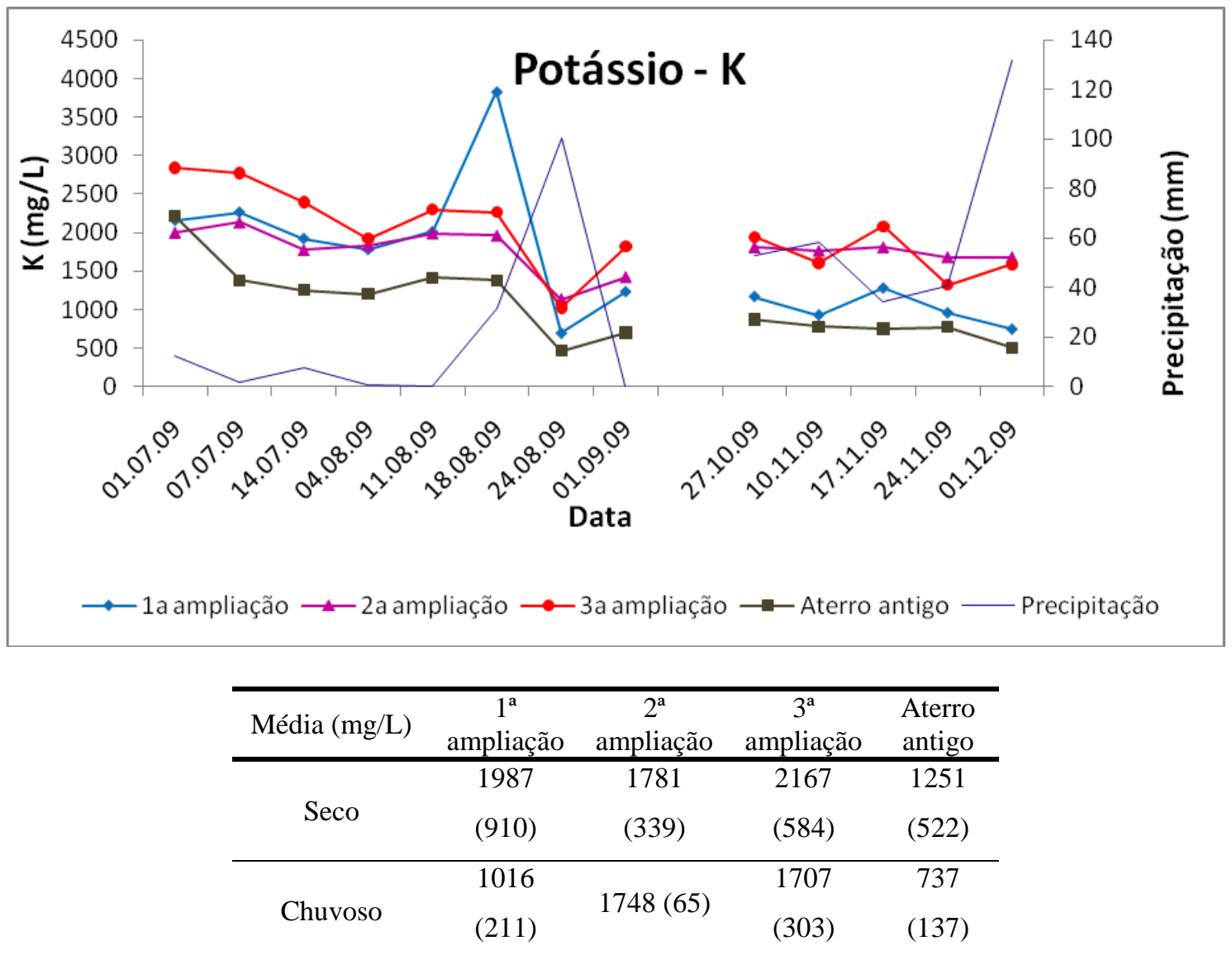

* ( ) Desvio padrão

FIGURA 5.9.8: Comportamento do potássio

Diferente do que ocorreu com o sódio, não houve acréscimo considerável na concentração de potássio no dia 11/08/09. Porém, no dia 24/08/09 a precipitação novamente provocou um decréscimo na concentração do metal em análise.

Durante o período chuvoso o potássio apresentou comportamento semelhante ao sódio, já que também foram poucas as variações observadas ao longo do tempo. As $2^{\mathrm{a}} \mathrm{e}$ $3^{\mathrm{a}}$ ampliações resultaram em valores médios muito próximos e o aterro antigo teve o menor valor médio. 
Ao se analisar o resultado de todos estes metais, sugere-se que o processo de lixiviação ocorre de forma rápida. Decorrido pouco tempo do aterramento dos resíduos, as concentrações dos metais encontradas são baixas ou mesmo inexistentes. As baixas concentrações de metais no lixiviado do aterro de São Carlos também podem estar ligadas à implantação da coleta seletiva no município. A coleta evita que vários objetos metálicos, como latas, cheguem ao aterro e contribuam para a alta concentração de metais no lixiviado.

\subsection{BIODEGRADABILIDADE DO LIXIVIADO}

\section{Relação AVT/DQO}

CONTRERA (2008) sugere que a relação AVT/DQO talvez seja a melhor relação para representar a biodegradabilidade anaeróbia de lixiviados de aterros sanitários. As Tabela 5.12.1 e 5.12.2 apresentam estes resultados para o período seco e chuvoso respectivamente. Os valores de AVT utilizados nesta relação foram os valores sem a correção sugerida por CONTRERA (2008). 
TABELA 5.12.1: Valores da relação AVT/DQO para o período seco

\begin{tabular}{ccccc}
\hline Data & $\begin{array}{c}\mathbf{1}^{\text {a }} \\
\text { ampliação }\end{array}$ & $\begin{array}{c}\mathbf{2}^{\mathbf{a}} \\
\text { ampliação }\end{array}$ & $\begin{array}{c}\mathbf{3}^{\mathbf{a}} \\
\text { ampliação }\end{array}$ & $\begin{array}{c}\text { Aterro } \\
\text { Antigo }\end{array}$ \\
\hline 03.06 .09 & 0,093 & 0,101 & 0,143 & \\
17.06 .09 & 0,084 & 0,089 & 0,046 & \\
25.06 .09 & 0,114 & 0,107 & 0,108 & 0,073 \\
01.07 .09 & 0,099 & 0,120 & 0,089 & 0,072 \\
07.07 .09 & 0,087 & 0,101 & 0,080 & 0,088 \\
14.07 .09 & 0,090 & 0,103 & 0,073 & 0,103 \\
04.08 .09 & 0,108 & 0,107 & 0,088 & 0,084 \\
11.08 .09 & 0,117 & 0,120 & 0,100 & 0,095 \\
18.08 .09 & 0,102 & 0,107 & 0,096 & 0,109 \\
24.08 .09 & 0,120 & 0,179 & 0,179 & 0,138 \\
01.09 .09 & 0,111 & 0,137 & 0,078 & 0,092 \\
\hline MÉDIA & $\mathbf{0 , 1 0 2}$ & $\mathbf{0 , 1 1 6}$ & $\mathbf{0 , 0 9 8}$ & $\mathbf{0 , 0 9 5}$ \\
\hline
\end{tabular}

TABELA 5.12.2: Valores da relação AVT/DQO para o período chuvoso

\begin{tabular}{ccccc}
\hline Data & $\begin{array}{c}\mathbf{1}^{\mathbf{a}} \\
\text { ampliação }\end{array}$ & $\begin{array}{c}\mathbf{2}^{\mathbf{a}} \\
\text { ampliação }\end{array}$ & $\begin{array}{c}\mathbf{3}^{\text {a }} \\
\text { ampliação }\end{array}$ & $\begin{array}{c}\text { Aterro } \\
\text { Antigo }\end{array}$ \\
\hline 27.10 .09 & 0,136 & 0,122 & 0,099 & 0,108 \\
10.11 .09 & 0,132 & 0,178 & 0,116 & 0,117 \\
17.11 .09 & 0,123 & 0,139 & 0,112 & 0,110 \\
24.11 .09 & 0,131 & 0,145 & 0,163 & 0,075 \\
01.12 .09 & 0,117 & 0,132 & 0,139 & 0,105 \\
\hline MÉDIA & $\mathbf{0 , 1 2 8}$ & $\mathbf{0 , 1 4 3}$ & $\mathbf{0 , 1 2 6}$ & $\mathbf{0 , 1 0 3}$ \\
\hline
\end{tabular}

Segundo CONTRERA (2008) para valores de relações AVT/DQO inferiores a 0,25 o lixiviado possui baixa biodegradabilidade, para relações entre 0,25 e 0,40 , possui média biodegradabilidade e possui elevada biodegradabilidade anaeróbia para relações superiores a 0,40 .

Pelos resultados observados conclui-se que o lixiviado do aterro de São Carlos possui baixa biodegradabilidade anaeróbia. As áreas mais recentes de operação do aterro mostraram valores de relação AVT/DQO muito próximos de áreas operadas há 
mais tempo e que hoje estão encerradas. Estes valores da relação AVT/DQO sugerem que todo o lixiviado do aterro já se encontra na fase metanogênica de decomposição da matéria orgânica.

\section{Relação STV/ST}

A relação entre sólidos totais voláteis e sólidos totais (STV/ST) é um indicativo da quantidade de matéria orgânica no lixiviado, porém esta não é a melhor relação para o caso de lixiviados. A Tabela 5.12.3 apresenta os resultados obtidos para o período seco e a Tabela 5.12.4 mostra os resultados do período chuvoso.

TABELA 5.12.3: Relação STV/ST para o período seco

\begin{tabular}{cccccc}
\hline Data & $\begin{array}{c}\mathbf{1}^{\mathbf{a}} \\
\text { ampliação }\end{array}$ & $\begin{array}{c}\mathbf{2}^{\mathbf{a}} \\
\text { ampliação }\end{array}$ & $\begin{array}{c}\mathbf{3}^{\mathbf{a}} \\
\text { ampliação }\end{array}$ & Mistura & $\begin{array}{c}\text { Aterro } \\
\text { Antigo }\end{array}$ \\
\hline 03.06 .09 & 0,490 & 0,222 & 0,213 & 0,454 & \\
17.06 .09 & 0,480 & 0,363 & 0,217 & 0,395 & \\
25.06 .09 & 0,391 & 0,218 & 0,201 & 0,224 & 0,266 \\
01.07 .09 & 0,406 & 0,243 & 0,234 & 0,498 & 0,221 \\
07.07 .09 & 0,480 & 0,447 & 0,227 & 0,247 & 0,265 \\
14.07 .09 & 0,338 & 0,212 & 0,193 & 0,229 & 0,261 \\
04.08 .09 & 0,496 & 0,415 & 0,278 & 0,238 & 0,258 \\
11.08 .09 & 0,515 & 0,461 & 0,221 & 0,236 & 0,268 \\
18.08 .09 & 0,499 & 0,385 & 0,295 & 0,235 & 0,250 \\
24.08 .09 & 0,330 & 0,241 & 0,313 & 0,307 & 0,285 \\
01.09 .09 & 0,309 & 0,266 & 0,241 & 0,269 & 0,245 \\
\hline MÉDIA & $\mathbf{0 , 4 3 0}$ & $\mathbf{0 , 3 1 6}$ & $\mathbf{0 , 2 3 9}$ & $\mathbf{0 , 3 0 3}$ & $\mathbf{0 , 2 5 8}$ \\
\hline
\end{tabular}


TABELA 5.12.4: Relação STV/ST para o período chuvoso

\begin{tabular}{ccccc}
\hline Data & $\begin{array}{c}\mathbf{1}^{\mathbf{a}} \\
\text { ampliação }\end{array}$ & $\begin{array}{c}\mathbf{2}^{\mathbf{a}} \\
\text { ampliação }\end{array}$ & $\begin{array}{c}\mathbf{3}^{\text {a }} \\
\text { ampliação }\end{array}$ & $\begin{array}{c}\text { Aterro } \\
\text { Antigo }\end{array}$ \\
\hline 27.10 .09 & 0,259 & 0,287 & 0,339 & 0,209 \\
10.11 .09 & 0,192 & 0,295 & 0,278 & 0,258 \\
17.11 .09 & 0,262 & 0,233 & 0,242 & 0,276 \\
24.11 .09 & 0,289 & 0,265 & 0,280 & 0,274 \\
01.12 .09 & 0,289 & 0,284 & 0,300 & 0,263 \\
\hline MÉDIA & $\mathbf{0 , 2 5 8}$ & $\mathbf{0 , 2 7 3}$ & $\mathbf{0 , 2 8 8}$ & $\mathbf{0 , 2 5 6}$ \\
\hline
\end{tabular}

De acordo com CONTRERA (2008), para valores de relações STV/ST inferiores a 0,3, o lixiviado do aterro de São Carlos possui baixa biodegradabilidade, para relações entre 0,3 e 0,4 possui média biodegradabilidade e possui elevada biodegradabilidade anaeróbia para relações superiores a 0,4.

Apesar de não ser a melhor relação para estudo de biodegradabilidade em lixiviados, a partir dos resultados obtidos, conclui-se que o lixiviado do aterro de São Carlos possui baixa biodegradabilidade anaeróbia, exceto pela $1^{\mathrm{a}}$ ampliação, que apresentou valores maiores que 0,4 no período seco. Assim como a relação AVT/DQO, os resultados da relação STV/ST também indicam que o lixiviado do aterro já se encontra na fase metanogênica de degradação da matéria orgânica.

\subsection{CONSIDERAÇÕES SOBRE OS RESULTADOS OBTIDOS}

Analisando-se todos os resultados obtidos durante a pesquisa algumas considerações procedem:

Os resultados da maioria das análises sugerem que o lixiviado de todos os pontos de amostragem do aterro já se encontra em fase avançada de decomposição da matéria orgânica. Uma hipótese para este fato está na presença do "colchão drenante" em todas as ampliações. Ele, além de proporcionar uma 
coleta mais eficiente do lixiviado, funciona como um filtro biológico, realizando um tratamento biológico prévio do lixiviado. Sendo assim, é de se esperar que o lixiviado de todos os pontos de coleta apresente características recalcitrantes ou de lixiviados "velhos".

Esperava-se que somente o aterro antigo e as $1^{\mathrm{a}}$ e $2^{\mathrm{a}}$ ampliações apresentassem características de lixiviado "velho", porém o lixiviado da $3^{\mathrm{a}}$ ampliação também se comportou de forma análoga.

A precipitação pluviométrica interfere em grande parte das variáveis consideradas neste estudo. Na data de maior precipitação - 24/08/09 - verificouse um decréscimo na concentração de parâmetros como DQO, alcalinidade, NTK, N amoniacal e sólidos. Entretanto, pH e AVT não ficaram sujeitos a grandes alterações durante este mesmo período. Uma possibilidade para justificar a influência da precipitação em alguns parâmetros analisados é que esta interfere na atividade biológica do aterro.

As concentrações de metais encontradas no vários pontos de coleta foram menores que as concentrações determinadas como limite máximo permitido pelas Resoluções CONAMA 357/05 e 397/08 de lançamento de efluentes em corpos d’água.

Ao se considerar a porcentagem de $\mathrm{N}$ amoniacal presente no NTK conclui-se que a amônia é realmente o poluente presente em maior quantidade no lixiviado. As relações que analisam a biodegradabilidade do lixiviado mostraram que o lixiviado do aterro de São Carlos apresenta baixa biodegradabilidade.

$>$ Durante o período chuvoso esperava-se que a alta precipitação pluviométrica pudesse evidenciar e/ou diferenciar alguma característica particular de algum ponto de coleta. Durante este período ficou evidenciado que a $2^{\mathrm{a}}$ ampliação 
apresentou as maiores concentrações de alcalinidade, ácidos voláteis, DQO e sólidos. 


\section{CONCLUSÕES}

Com base nos resultados obtidos neste trabalho, pode-se concluir que:

O lixiviado de todos os pontos de amostragem encontra-se na fase metanogênica de decomposição da matéria orgânica;

A relação AVT/DQO, utilizada na investigação da biodegradabilidade do lixiviado, resultou em valores inferiores a $0,25 \mathrm{em}$ todos os pontos de amostragem, indicando que o lixiviado possui baixa biodegradabilidade;

A relação STV/ST, embora não seja muito apropriada para o caso de lixiviados, apresentou valores inferiores a 0,3 e indicou baixa quantidade de matéria orgânica nos lixiviados do aterro de São Carlos;

$>$ A amônia é o poluente presente em maior quantidade no lixiviado, representando cerca de $70 \%$ do NTK;

A precipitação influenciou a concentração de alguns parâmetros, entre eles a DQO (decréscimo de 4000mg/L para $3000 \mathrm{mg} / \mathrm{L}$ na ocorrência de forte precipitação), NTK (decréscimo de $3000 \mathrm{mg} / \mathrm{L}$ para $1500 \mathrm{mg} / \mathrm{L}$ ) e ST (valores foram reduzidos a metade em todos os pontos);

$>\mathrm{O}$ comportamento de outros parâmetros não se mostrou intimamente ligado a precipitação. O SST e os metais como ferro, chumbo e cádmio não apresentaram relação alguma entre concentração presente na amostra e precipitação ocorrida no aterro;

$>$ A presença de AVT pode ser justificada pela presença de substâncias de caráter ácido (ácidos húmicos, fúlvicos) e não necessariamente de ácidos voláteis; 


\section{RECOMENDAÇÕES PARA TRABALHOS FUTUROS}

Considerando-se os resultados obtidos e visando contribuir para o desenvolvimento desta linha de pesquisa, recomenda-se:

Acompanhamento e monitoramento das características do lixiviado durante o período mínimo de 1 ou 2 anos, semanalmente;

Investigar a origem do metal presente no lixiviado, ou seja, determinar se ele é proveniente do resíduo aterrado ou do solo de cobertura do aterro;

Estudar a relação entre gás gerado no aterro e as fases de decomposição dos resíduos no aterro sanitário. 


\section{REFERÊNCIAS BIBLIOGRÁFICAS}

APHA; AWWA; WPCF (2005) Standard methods for the examination of water and wastewater. 21th Edition. Washington. American Public Health Association, American Water Works Association, Water Environment Federation. Washington - DC, USA.

ASSOCIAÇÃO BRASILEIRA DE NORMAS TÉCNICAS - ABNT (2004) NBR 10004 - Resíduos sólidos - classificação. Rio de Janeiro, ABNT.

ASSOCIAÇÃO BRASILEIRA DE NORMAS TÉCNICAS - ABNT (1992) NBR 8419 - Apresentação de projetos de aterros sanitários de resíduos sólidos urbanos. Rio de Janeiro, ABNT.

BAUN, D. L.; CHRISTENSEN, T. H. (2004) Speciation of heavy metals in landfill leachate: a review. Waste Management \& Research. vol 22, pp. 3-23.

BIDONE, F.R.A. e POVINELLI, J. (1999) Conceitos básicos de resíduos sólidos. São Carlos, EESC/USP.

BIDONE, R. F.; HARTAMANN, F.; ROSA, A. L.; SOUTO, G. A. B.; POVINELLI, J. (2007) Filtros anaeróbios aplicados ao tratamento de lixiviado de aterro sanitário. In: $24^{\circ}$ Congresso Brasileiro de Engenharia Sanitária e Ambiental. Belo Horizonte, MG.

BIDONE, R. F. (2008) Tratamento de lixiviado de aterro sanitário por um sistema composto por filtros anaeróbios seguidos de banhados construídos: estudo de caso - central de resíduos do Recreio, Minas do Leão/RS. São Carlos, 2008. Dissertação de mestrado - Escola de Engenharia de São Carlos, Universidade de São Paulo.

BORZANI, W.; LIMA, U. A.; AQUARONE, E. (1975) Tópicos de microbiologia industrial. $1^{\text {a }}$ Ed. São Paulo: Blücher-EdUSP, 231p., v.2 (série Biotecnologia, 5v.) pp. 46-76.

CASTRO, M. C. A. A. de (2001) Avaliação de um sistema australiano de lagoas no tratamento conjunto de esgoto sanitário e líquidos percolados gerados em aterro sanitário. São Carlos, 2001. Tese de Doutorado - Escola de Engenharia de São Carlos, Universidade de São Paulo.

CHEN, K. Y.; BOWERMAN, F. R. (1974) Mechanisms of leachate formation in sanitary landfills. In: YEN, T. F. Recycling and disposal of solid wastes: industrial, agricultural, domestic. Ann Arbor: Ann Arbor Science Publishers, Cap 12, pp. 349 367.

CONSELHO NACIONAL DE MEIO AMBIENTE - CONAMA (1986) CONAMA 001 - Dispõe sobre critérios básicos e diretrizes gerais para o Relatório de Impacto Ambiental - RIMA. Brasília, CONAMA.

CONSELHO NACIONAL DE MEIO AMBIENTE - CONAMA (2005) CONAMA 357 - Dispõe sobre a classificação dos corpos de água e diretrizes ambientais para o seu enquadramento, bem como estabelece as condições e padrões de lançamento de efluentes, e dá outras providências. Brasília, CONAMA. 
CONSELHO NACIONAL DE MEIO AMBIENTE - CONAMA (2008) CONAMA 397 - Altera o inciso II do $\$ 4^{\circ}$ e a Tabela $X$ do $\$ 5^{\circ}$ do art. 34 da Resolução CONAMA $\mathrm{n}^{\mathbf{0} 357 / 05}$ e acrescenta os $\$ 6^{\circ}$ e $7^{\circ}$. Brasília, CONAMA.

CONTRERA, R. C. (2008) Estudo da tratabilidade de lixiviados de aterros sanitários em sistema de reatores anaeróbio e aeróbio operados em bateladas seqüenciais e em um filtro biológico anaeróbio contínuo de fluxo ascendente. São Carlos, 2008. Tese de Doutorado - Escola de Engenharia de São Carlos, Universidade de São Paulo.

DACANAL, M.; BEAL, L. L. (2007) Tratamento de lixiviado através de filtro anaeróbio associado à membrana de microfiltração. In: $24^{\circ}$ Congresso Brasileiro de Engenharia Sanitária e Ambiental. Belo Horizonte, MG.

DIAMADOPOULOS, E. (1994) Characterization and treatment of recirculationstabilized leachate. Water Research, vol.28, pp.2439- 2445.

DILALLO, R.; ALBERTSON, O. E. (1961) Volatile acides by direct titration. Journal Water Pollution Control Federation, vol.33, nº4, pp.350-364.

EHRIG, H. J. (1983) Quality and quantity of sanitary landfill leachate. Waste Management \& Research, vol.1, pp.53 - 68.

EMBRAPA PECUÁRIA SUDESTE - DADOS METEOROLÓGICOS Disponível em: < https://www.cppse.embrapa.br/080servicos/dados-meteorologicos> Acesso em: 5 de novembro de 2009.

FARQUHAR, G. J.; ROVERS, F. A. (1973) Gás production during refuse decomposition. Water, Air e Soil Pollution, n², pp. 483-495.

FERREIRA, F. A. (2008) Avaliação da viabilidade do tratamento de líquidos percolados em estação de tratamento de esgoto. São Carlos, 2008. Monografia de Graduação em Engenharia Ambiental - Escola de Engenharia de São Carlos, Universidade de São Paulo.

FRÉSCA, F. R. C. (2007) Estudo da geração de resíduos sólidos domiciliares no município de São Carlos - SP, a partir da caracterização física. São Carlos, 2007. Dissertação de Mestrado - Escola de Engenharia de São Carlos, Universidade de São Paulo.

GOMES, L. P. (1989) Estudo da caracterização física da biodegradabilidade dos resíduos sólidos urbanos em aterros sanitários. São Carlos, 1989. Dissertação de Mestrado - Escola de Engenharia de São Carlos, Universidade de São Paulo.

IPT/CEMPRE (2000) Lixo municipal - manual de gerenciamento integrado. $2^{\text {a }}$ Ed., São Paulo. 
JARDIM, N. S. (1995) Lixo municipal: manual de gerenciamento integrado. Nilza Silva Jardim (Coordenador). $1^{\text {a }}$ Ed. São Paulo: Instituto de Pesquisas Tecnológicas IPT, Compromisso Empresarial para Reciclagem - CEMPRE. (Publicação IPT 2163), $278 \mathrm{p}$.

KJELDEN, P.; CHRISTENSEN, T. H. (2001) A simple model for the distribution and fate of organic chemicals in a landfill: MOCLA. Waste Management \& Research. vol. 19, pp. 201-216.

KJELDEN, P.; CHRISTOPHERSEN, M. (2001) Composition of leachate from old landfills in Denmark. Waste Management \& Research. vol 19, pp. 249-256.

KJELDSEN, P.; BARLAZ, M. A.; ROOKER, A. P.; BAUN, A.; LEDIN, A.; CHRISTENSEN, T. H. (2002) Present and long-term composition of MSW landfill leachate: a review. Critical Reviews in Environmental Science and Technology, 32 (4), pp. 297-336.

LEITE, W. C. A. (1991) Estudo do comportamento da temperatura, pH e teor de umidade na decomposição de resíduos sólidos urbanos em aterros sanitários. São Carlos, 1991. Dissertação de Mestrado - Escola de Engenharia de São Carlos, Universidade de São Paulo.

LEITE, W. C. A. (1997) Estudo da gestão de resíduos sólidos: uma proposta de modelo tomando a unidade de gerenciamento de recursos hídricos (UGRHI-5) como referência. São Carlos, 1997. Tese de Doutorado - Escola de Engenharia de São Carlos, Universidade de São Paulo.

LIMA, L. M. Q. (1995) Lixo: tratamento e biorremediação. $3^{\text {a }}$ Ed. São Paulo, 265p.

LOPES, A. A. (2007) Estudo da gestão integrada dos resíduos sólidos urbanos na bacia Tietê-Jacaré (UGRHI-13). São Carlos, 2007. Tese de Doutorado - Escola de Engenharia de São Carlos, Universidade de São Paulo.

MCBEAN, E. A.; ROVERS, F. A.; FARQUHAR, G. J. (1995) Solid waste landfill engineering and design. Englewood Cliffs, New Jersey, EUA: Prentice-Hall PTR, $521 \mathrm{p}$.

METCALF, L.; EDDY, H. P. (2003) Wastewater engineering: treatment, disposal, reuse. EUA, McGraw-Hill, 4a ed., 1819p.

MONTEIRO, V. E. D.; JUCÁ, J. F. T.; RÊGO, C. C. (2001) Influência das condições climáticas no comportamento do aterro de resíduos sólidos da Muriceba. In: Congresso Brasileiro de Engenharia Sanitária e Ambiental, 21, 2001, João Pessoa, PB.

POHLAND, F. G.; KANG, S. J. (1971) Sanitary landfill stabilization with leachate recycle and residual treatment. Aiche Symposium Series. vol. 71, n. 145, pp. 308318. 
POHLAND, F. G. (1975) Sanitary landfill stabilization with leachate recycle and residual treatment. EPA - Environmental Protection Agency. Washington, D.C.

POHLAND, F. G.; HARPER, S. R. (1985) Critical review and summary of leachate and gas production from landfills. Tech Project n. E20 G01.

POHLAND, F. G.; GOULD, J. P. (1986) Co-disposal of municipal refuse and industrial waste sludge in landfills. Water Science and Technology, vol.18, pp.177 192.

PMSC - PREFEITURA MUNICIPAL DE SÃO CARLOS (2007) Relatório ambiental preliminar do projeto de ampliação do aterro sanitário municipal de São Carlos SP. São Carlos, 2007. Secretaria Municipal de Desenvolvimento Sustentável, Ciência e Tecnologia.

PMSC - PREFEITURA MUNICIPAL DE SÃO CARLOS (2010) Disponível em: www.saocarlos.sp.gov.br. Acessado em 15 de março de 2010.

REES, J. F. (1980) Optimization of methane production and refuse decomposition in landfills by temperature control. Journal of Chemical Technology and Biotechnology, vol.30, pp. $458-465$.

SANCHEZ, L. E. (2001) Desengenharia: o passivo ambiental na desativação de empreendimentos industriais. São Paulo, 2001. EdUSP, 254p.

SCHALCH, V. (1984) Produção e características do chorume em processo de decomposição do lixo urbano. São Carlos, 1984. Dissertação de Mestrado - Escola de Engenharia de São Carlos, Universidade de São Paulo.

SCHALCH, V. (1992) Análise comparativa do comportamento de dois aterros sanitários semelhantes e correlações dos parâmetros do processo de digestão anaeróbia. São Carlos, 1992. Tese de Doutorado - Escola de Engenharia de São Carlos, Universidade de São Paulo.

SISTEMA NACIONAL DE INFORMAÇÕES SOBRE SANEAMENTO. MINISTÉRIO DAS CIDADES (2006) Diagnóstico do manejo de resíduos sólidos urbanos. Brasília, 2006. Disponível em: <www.snis.gov.br>. Acesso em 27 de julho de 2009.

SOUTO, G. A. B.; POVINELLI, J. (2007) Características do lixiviado de aterros sanitários no Brasil. In: $24^{\circ}$ Congresso Brasileiro de Engenharia Sanitária e Ambiental. Belo Horizonte, MG.

SOUTO, G. A. B. (2009) Lixiviado de aterros sanitários - estudo da remoção do nitrogênio amoniacal por processo de arraste com ar ("stripping"). São Carlos, 2009. Tese de Doutorado - Escola de Engenharia de São Carlos, Universidade de São Paulo. 
TCHOBANOGLOUS, G.; THEISEN H.; VIGIL S. A. (1993) Integrated solid waste management: Engineering principles and management issues. EUA, McGraw-Hill.

THOMAS, D. J. L.; TYRREL, S. F.; SMITH, R.; FARROW, S. (2009) Bioassays for the evaluation of landfill leachate toxicity. Journal of Toxicology and Environmental Health, Part B, vol. 12, pp. 83-105.

ZIYANG, L.; YOUCAI, Z.; TAO, Y.; YU, S.; HUILI, C.; NANWEN, Z.; RENHUA, H. (2009) Natural attenuation and characterization of contaminants composition in landfill leachate under different disposing ages. Science of Total Environment. vol. 407, pp. 3385-3391. 


\section{ANEXO A - ANÁLISES FÍSICO - QUÍMICAS DAS AMOSTRAS}

Neste anexo são apresentadas as análises realizadas neste trabalho, bem como os procedimentos e as modificações, quando necessárias, em cada análise.

É importante esclarecer que as recomendações de amostragem, preservação e tempo de armazenamento, mostradas abaixo são referentes ao esgoto sanitário. Todas as amostras do lixiviado foram coletadas em frascos de polietileno, mantidas sob refrigeração e analisadas o mais rapidamente possível.

\section{1. pH}

Amostragem: Polietileno ou vidro

Volume mínimo: $50 \mathrm{~mL}$

Tipo de amostra: Simples

Preservação: Análise imediata

Tempo de armazenamento: 15 minutos

Procedimento:

Remover o eletrodo da água e lavá-lo com água destilada. Enxugar com papel macio;

Verificar se o eletrodo encontra-se calibrado. Senão, realizar a calibração;

Colocar $50 \mathrm{~mL}$ da amostra em um béquer;

Colocar o "peixinho" no béquer para agitar a amostra;

Imergir o eletrodo na amostra, esperar a estabilização do aparelho e fazer a leitura.

\section{ALCALINIDADE TOTAL}

Amostragem: Polietileno ou vidro 
Volume mínimo: $200 \mathrm{~mL}$

Tipo de amostra: Simples

Preservação: Refrigeração

Tempo de armazenamento: 24 horas

Procedimento:

Filtrar a amostra em membrana de fibra de vidro com $47 \mathrm{~mm}$ de diâmetro e abertura dos poros de $2,0 \mu \mathrm{m}$;

Diluir a amostra em 1:10;

Colocar $50 \mathrm{~mL}$ da amostra filtrada e diluída em um béquer;

Colocar o "peixinho" no béquer para agitar a amostra;

Titular a amostra com solução de $\mathrm{H}_{2} \mathrm{SO}_{4}$ aproximadamente $0,2 \mathrm{~N}$ até $\mathrm{pH} 4,3$;

Anotar o volume de ácido gasto;

É utilizada a seguinte expressão para cálculo da alcalinidade:

$$
\text { Alcalinida de }\left(\mathrm{mg} / \mathrm{LCaCO}_{3}\right)=\frac{\mathrm{N}_{\mathrm{H}_{2} \mathrm{SO}_{4}}}{V_{\text {amostra }}} x V_{\mathrm{H}_{2} \mathrm{SO}_{4}} x 50000
$$

Embora o Standard Methods não recomende, as determinações de alcalinidade foram feitas com amostras diluídas em 1:10. Segundo CONTRERA (2008), a determinação em amostras sem diluição é praticamente inviável, devido ao tempo que se gasta e à formação de espuma, que chega a transbordar do béquer.

\section{3. ÁCIDOS VOLÁTEIS TOTAIS - AVT}

Amostragem: Frasco âmbar

Volume mínimo: $200 \mathrm{~mL}$

Tipo de amostra: Simples, composta

Preservação: Refrigeração 
Tempo de armazenamento: 7 dias

Procedimento:

Ajustar pH da amostra utilizada para análise da alcalinidade para 3,4;

Acrescentar as bolinhas de vidro no béquer com a amostra;

Colocar a amostra sobre a chapa aquecedora;

Ferver a amostra por aproximadamente 3 minutos;

Resfriar a amostra em temperatura ambiente;

> Titular a amostra com solução de $\mathrm{NaOH}$ aproximadamente 0,1 até pH 4,0;

Titular novamente com solução de $\mathrm{NaOH}$ aproximadamente 0,1 do pH 4,0 até pH 7,0;

Anotar o volume de base gasto nesta última titulação;

Os ácidos voláteis totais são calculados por:

$$
\operatorname{Ácidos}\left(m g / \mathrm{LCaCO}_{3}\right)=\frac{N_{\mathrm{NaOH}}}{V_{\text {amostra }}} \times V_{\mathrm{NaOH}} \times 50000
$$

Para análise de AVT pode-se aproveitar a amostra utilizada na alcalinidade, diminuindo a quantidade necessária de lixiviado a ser coletado.

\section{DEMANDA QUÍMICA DE OXIGÊNIO - DQO}

Amostragem: Polietileno ou vidro

Volume mínimo: $100 \mathrm{~mL}$

Tipo de amostra: Simples, composta

Preservação: Adição de $\mathrm{H}_{2} \mathrm{SO}_{4}$ até $\mathrm{pH}<2$

Tempo de armazenamento: 7 dias

Procedimento:

Diluir a amostra em 1:10, 1:4 ou 1:2 (dependendo da necessidade); 
Realizar a análise em duplicata para cada amostra e para o branco (feito com água destilada);

$>$ Colocar 1,5 mL da solução de dicromato e 3,5 mL da solução de ácido no tubo para análise;

Homogeneizar a amostra;

Adicionar $2 \mathrm{~mL}$ da amostra no tubo;

Fechar com cuidado o tubo;

Encaminhar ao digestor a $150^{\circ} \mathrm{C}$ por 2 horas;

Esfriar o tubo para que seja possível realizar a leitura no espectrofotômetro;

Utilizar o programa 955 no espectrofotômetro e fazer a leitura no comprimento de onda de $620 \mathrm{~nm}$;

Zerar o equipamento com o branco;

Limpar o tubo com esponja de aço e papel macio, para retirar resíduos ou arranhões que atrapalhem a leitura;

Não agitar o tubo para que o cloreto de mercúrio precipitado no fundo não altere a leitura;

Descartar o resíduo em recipiente adequado.

\section{SÓLIDOS - SÉRIE COMPLETA}

Amostragem: Polietileno ou vidro

Volume mínimo: $200 \mathrm{~mL}$

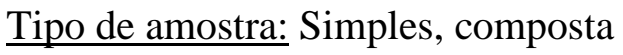

Preservação: Refrigerada

Tempo de armazenamento: 7 dias

Procedimento: 


\section{Sólidos totais}

Preparação: cadinho limpo e levado a mufla por 2 horas a $550^{\circ} \mathrm{C}$;

Pesar o cadinho e obter P0;

Transferir $100 \mathrm{~mL}$ da amostra bruta para o cadinho;

Levar o cadinho à estufa por 12 horas a $105^{\circ} \mathrm{C}$;

Depois de decorrido este tempo, esfriar o cadinho no dessecador;

Pesar o cadinho e obter P1;

Levar o cadinho para mufla por 2 horas;

Depois de decorrido este tempo, esfriar o cadinho no dessecador;

Pesar o cadinho e obter P2.

Os sólidos totais (ST), sólidos totais fixos (STF) e sólidos totais voláteis (STV) são calculados por:

$$
\begin{gathered}
S T=\frac{(P 1-P 0)}{\text { vol.amostra }} x 1000 \\
S T F=\frac{(P 2-P 0)}{\text { vol.amostra }} x 1000 \\
S T V=S T-S T F
\end{gathered}
$$

\section{Sólidos suspensos}

Preparação: membrana de fibra de vidro com $47 \mathrm{~mm}$ de diâmetro e abertura de poros de $2,0 \mu \mathrm{m}$ colocada no cadinho e molhada, levada a mufla por 15 minutos;

Filtrar a amostra na membrana (o volume a ser filtrado vai depender. Filtrar até que a membrana ofereça resistência à filtração);

Proceder de maneira análoga à análise de sólidos totais. 
Os sólidos dissolvidos totais (SDT), sólidos dissolvidos fixos (SDF), sólidos dissolvidos voláteis (SDV), sólidos suspensos totais (SST), sólidos suspensos voláteis (SSV) e sólidos suspensos fixos (SSF) são calculados por:

$$
\begin{gathered}
S D T=\frac{(P 1-P 0)}{\text { vol.amostra }} \times 1000 \\
S D F=\frac{(P 2-P 0)}{\text { vol.amostra }} \times 1000 \\
S D V=S D T-S D F \\
S S T=S T-S D T \\
S S V=S T V-S D V \\
S S F=S T F-S D F
\end{gathered}
$$

\section{METAIS}

Amostragem: Polietileno ou vidro enxaguado com $\mathrm{HNO}_{3}$

Volume mínimo: $100 \mathrm{~mL}$

Tipo de amostra: Simples, composta

Preservação: Para metais dissolvidos filtre imediatamente e adicione $\mathrm{HNO}_{3}$ até $\mathrm{pH}<2$ Tempo de armazenamento: 6 meses

Procedimento:

Colocar 50 mL da amostra sem diluição em um erlenmeyer;

Acrescentar 6 mL de ácido nítrico 50\%; 
Ferver o frasco até que diminua bastante o volume (restar cerca de $15 \mathrm{~mL}$ );

Esfriar o frasco à temperatura ambiente;

Colocar $10 \mathrm{~mL}$ de ácido nítrico 50\%;

Ferver o frasco até que diminua bastante o volume (restar cerca de $15 \mathrm{~mL}$ );

Esfriar o frasco à temperatura ambiente;

Acrescentar $5 \mathrm{~mL}$ de ácido clorídrico 50\% e 7,5 mL de água destilada;

Ferver o frasco pela última vez e esfriar à temperatura ambiente;

> Transferir o líquido para uma proveta de $50 \mathrm{~mL}$ com tampa e completar com água destilada;

Transferir para o tubo de análise;

A leitura é feita pelo técnico do laboratório na absorção atômica.

\section{NITROGÊNIO AMONIACAL - NH}

Amostragem: Polietileno ou vidro

Volume mínimo: $500 \mathrm{~mL}$

Tipo de amostra: Simples, composta

Preservação: Analisar o mais rápido possível ou adicionar $\mathrm{H}_{2} \mathrm{SO}_{4}$ até $\mathrm{pH}<2$ e refrigerar Tempo de armazenamento: 7 dias

Procedimento:

Colocar $100 \mathrm{~mL}$ de amostra diluída 1:10 em uma cubeta própria para análise de nitrogênio;

$>$ No erlenmeyer colocar $100 \mathrm{~mL}$ de solução de ácido bórico $2 \%$ e 5 gotas de indicador;

Posicionar a cubeta e o erlenmeyer no destilador;

Abrir a torneira de água! 
Ajustar o aparelho para delay 3s e destilação por 7 minutos;

A solução do erlenmeyer passa de marrom para azul;

$>$ Titular a amostra com solução de $\mathrm{H}_{2} \mathrm{SO}_{4}$ aproximadamente 0,2N (ponto de viragem = azul para laranja);

Anotar o volume de ácido;

$\mathrm{O} \mathrm{NH}_{3}$ é calculado por:

$$
\mathrm{NH}_{3}=\frac{V_{\text {Ácido }} \times N_{\text {Ácido }} \times 14000}{V_{\text {Amostra }}}-\text { Branco }
$$

$\mathrm{O}$ valor do branco era calculado realizando-se o processo com água destilada e era fornecido pelo laboratório. Neste caso foi informado o valor de 5mg/L.

\section{NITROGÊNIO TOTAL KJELDAHL - NTK}

Amostragem: Polietileno ou vidro

Volume mínimo: $500 \mathrm{~mL}$

Tipo de amostra: Simples, composta

Preservação: Refrigerar e adicionar $\mathrm{H}_{2} \mathrm{SO}_{4}$ até $\mathrm{pH}<2$

Tempo de armazenamento: 7 dias

Procedimento:

Pesar 10 g de catalisador para NTK e colocar na cubeta;

Colocar $25 \mathrm{~mL}$ de amostra;

Adicionar $20 \mathrm{~mL}$ de $\mathrm{H}_{2} \mathrm{SO}_{4}$;

Levar a cubeta ao digestor de nitrogênio $(15 \mathrm{~min}$ em potência 10 e $45 \mathrm{mi}$ em potência 8);

Após este tempo verificar se a solução ficou verde;

Esfriar a cubeta em temperatura ambiente;

No erlenmeyer colocar $100 \mathrm{~mL}$ de solução de ácido bórico $2 \%$ e 5 gotas de 
indicador;

Posicionar a cubeta e o erlenmeyer no destilador;

Abrir a torneira de água!

Ajustar o aparelho para $\mathrm{H}_{2} \mathrm{O} 50 \mathrm{~mL}, \mathrm{NaOH} 110 \mathrm{~mL}$, delay $3 \mathrm{~s}$ e destilação por 7 minutos;

A solução do erlenmeyer passa de marrom para azul;

Titular a amostra com solução de $\mathrm{H}_{2} \mathrm{SO}_{4}$ aproximadamente $0,2 \mathrm{~N}$ (ponto de viragem $=$ azul para laranja);

Anotar o volume de ácido;

O NTK é calculado por:

$$
N T K=\frac{V_{\text {Ácido }} \times N_{\text {Ácido }} \times 14000}{V_{\text {Amostra }}}-\text { Branco }
$$

De forma análoga ao N amoniacal, o valor de branco para NTK foi $14 \mathrm{mg} / \mathrm{L}$. 


\section{ANEXO B - RESULTADOS DAS ANÁLISES}

Neste anexo são apresentados os resultados das análises realizadas neste trabalho de pesquisa.

pH

TABELA B.1: Valores de $\mathrm{pH}$ no período seco

\begin{tabular}{ccccc}
\hline Data & $\begin{array}{c}\mathbf{1}^{\mathbf{a}} \\
\text { ampliação }\end{array}$ & $\begin{array}{c}\mathbf{2}^{\mathbf{a}} \\
\text { ampliação }\end{array}$ & $\begin{array}{c}\mathbf{3}^{\mathbf{a}} \\
\text { ampliação }\end{array}$ & $\begin{array}{c}\text { Aterro } \\
\text { Antigo }\end{array}$ \\
\hline 03.06 .09 & 8,25 & 8,07 & 8,43 & \\
17.06 .09 & 8,51 & 8,34 & 8,66 & \\
25.06 .09 & 8,27 & 8,12 & 7,98 & 8,12 \\
01.07 .09 & 8,39 & 8,26 & 8,23 & 8,51 \\
07.07 .09 & 8,37 & 8,18 & 8,54 & 8,34 \\
14.07 .09 & 8,33 & 8,22 & 8,62 & 8,43 \\
04.08 .09 & 8,34 & 8,18 & 8,66 & 8,37 \\
11.08 .09 & 8,37 & 8,19 & 8,66 & 8,31 \\
18.08 .09 & 8,50 & 8,41 & 8,80 & 8,35 \\
24.08 .09 & 8,06 & 8,05 & 8,53 & 8,30 \\
01.09 .09 & 8,13 & 8,14 & 8,63 & 8,38 \\
\hline MÉDIA & $\mathbf{8 , 3 2}$ & $\mathbf{8 , 2 0}$ & $\mathbf{8 , 5 2}$ & $\mathbf{8 , 3 5}$ \\
\hline
\end{tabular}

TABELA B.2: Valores de $\mathrm{pH}$ no período chuvoso

\begin{tabular}{ccccc}
\hline Data & $\begin{array}{c}\mathbf{1}^{\mathbf{a}} \\
\text { ampliação }\end{array}$ & $\begin{array}{c}\mathbf{2}^{\mathbf{a}} \\
\text { ampliação }\end{array}$ & $\begin{array}{c}\mathbf{3}^{\mathbf{a}} \\
\text { ampliação }\end{array}$ & $\begin{array}{c}\text { Aterro } \\
\text { Antigo }\end{array}$ \\
\hline 27.10 .09 & 8,25 & 8,35 & 8,75 & 8,49 \\
10.11 .09 & 8,15 & 8,19 & 8,53 & 8,44 \\
17.11 .09 & 8,06 & 8,18 & 8,45 & 8,32 \\
24.11 .09 & 8,23 & 8,21 & 8,51 & 8,49 \\
01.12 .09 & 8,14 & 8,26 & 8,56 & 8,38 \\
\hline MÉDIA & $\mathbf{8 , 1 7}$ & $\mathbf{8 , 2 4}$ & $\mathbf{8 , 5 6}$ & $\mathbf{8 , 4 2}$ \\
\hline
\end{tabular}




\section{ALCALINIDADE}

TABELA B3: Valores de alcalinidade no período seco (valores em mg/LCaCO${ }_{3}$ )

\begin{tabular}{ccccc}
\hline Data & $\begin{array}{c}\mathbf{1}^{\mathbf{a}} \\
\text { ampliação }\end{array}$ & $\begin{array}{c}\mathbf{2}^{\mathbf{a}} \\
\text { ampliação }\end{array}$ & $\begin{array}{c}\mathbf{3}^{\mathbf{a}} \\
\text { ampliação }\end{array}$ & $\begin{array}{c}\text { Aterro } \\
\text { Antigo }\end{array}$ \\
\hline 03.06 .09 & 10910 & 10910 & 7691 & \\
17.06 .09 & 9656 & 9677 & 5539 & \\
25.06 .09 & 11600 & 11328 & 8841 & 5434 \\
01.07 .09 & 10047 & 10579 & 8353 & 4807 \\
07.07 .09 & 11564 & 11820 & 10362 & 4767 \\
14.07 .09 & 11584 & 11446 & 9436 & 4846 \\
04.08 .09 & 11131 & 11564 & 6994 & 4098 \\
11.08 .09 & 11485 & 11446 & 6895 & 3881 \\
18.08 .09 & 10382 & 9397 & 4925 & 3369 \\
24.08 .09 & 4157 & 6836 & 4492 & 2541 \\
01.09 .09 & 7722 & 8609 & 6225 & 3881 \\
\hline MÉDIA & $\mathbf{1 0 0 2 1}$ & $\mathbf{1 0 3 2 8}$ & $\mathbf{7 2 5 0}$ & $\mathbf{4 1 8 0}$ \\
\hline
\end{tabular}

TABELA B.4: Valores de alcalinidade no período chuvoso (valores em mg/LCaCO 3 )

\begin{tabular}{ccccc}
\hline \multirow{2}{*}{ Data } & $\begin{array}{c}\mathbf{1}^{\mathbf{a}} \\
\text { ampliação }\end{array}$ & $\begin{array}{c}\mathbf{2}^{\mathbf{a}} \\
\text { ampliação }\end{array}$ & $\begin{array}{c}\mathbf{3}^{\mathbf{a}} \\
\text { ampliação }\end{array}$ & $\begin{array}{c}\text { Aterro } \\
\text { Antigo }\end{array}$ \\
\hline 27.10 .09 & 7266 & 10185 & 7476 & 3570 \\
10.11 .09 & 5670 & 11004 & 6699 & 3297 \\
17.11 .09 & 7812 & 11235 & 8253 & 3591 \\
24.11 .09 & 5964 & 10647 & 5817 & 3465 \\
01.12 .09 & 5040 & 10941 & 6741 & 3045 \\
\hline MÉDIA & $\mathbf{6 3 5 0}$ & $\mathbf{1 0 8 0 2}$ & $\mathbf{6 9 9 7}$ & $\mathbf{3 3 9 4}$ \\
\hline
\end{tabular}




\section{ÁCIDOS VOLÁTEIS TOTAIS - AVT}

TABELA B5: Valores de ácidos voláteis totais (AVT) no período seco (valores em

$\left.\mathrm{mg} / \mathrm{LCaCO}_{3}\right)$

\begin{tabular}{ccccc}
\hline Data & $\begin{array}{c}\mathbf{1}^{\mathbf{a}} \\
\text { ampliação }\end{array}$ & $\begin{array}{c}\mathbf{2}^{\mathbf{a}} \\
\text { ampliação }\end{array}$ & $\begin{array}{c}\mathbf{3}^{\mathbf{a}} \\
\text { ampliação }\end{array}$ & $\begin{array}{c}\text { Aterro } \\
\text { Antigo }\end{array}$ \\
\hline 03.06 .09 & 475 & 380 & 570 & \\
17.06 .09 & 475 & 380 & 143 & \\
25.06 .09 & 618 & 428 & 380 & 238 \\
01.07 .09 & 523 & 475 & 333 & 238 \\
07.07 .09 & 618 & 523 & 285 & 285 \\
14.07 .09 & 523 & 428 & 238 & 333 \\
04.08 .09 & 523 & 475 & 238 & 285 \\
11.08 .09 & 618 & 523 & 285 & 333 \\
18.08 .09 & 523 & 428 & 238 & 333 \\
24.08 .09 & 190 & 570 & 380 & 143 \\
01.09 .09 & 380 & 475 & 190 & 143 \\
\hline MÉDIA & $\mathbf{4 9 7}$ & $\mathbf{4 6 2}$ & $\mathbf{2 9 8}$ & $\mathbf{2 5 9}$ \\
\hline
\end{tabular}

TABELA B6: Valores de ácidos voláteis totais (AVT) no período chuvoso (valores em $\left.\mathrm{mg} / \mathrm{LCaCO}_{3}\right)$

\begin{tabular}{ccccc}
\hline Data & $\begin{array}{c}\mathbf{1}^{\mathbf{a}} \\
\text { ampliação }\end{array}$ & $\begin{array}{c}\mathbf{2}^{\mathbf{a}} \\
\text { ampliação }\end{array}$ & $\begin{array}{c}\mathbf{3}^{\text {a }} \\
\text { ampliação }\end{array}$ & $\begin{array}{c}\text { Aterro } \\
\text { Antigo }\end{array}$ \\
\hline 27.10 .09 & 328 & 410 & 267 & 185 \\
10.11 .09 & 252 & 693 & 263 & 179 \\
17.11 .09 & 357 & 525 & 326 & 189 \\
24.11 .09 & 273 & 504 & 357 & 116 \\
01.12 .09 & 210 & 525 & 452 & 137 \\
\hline MÉDIA & $\mathbf{2 8 4}$ & $\mathbf{5 3 1}$ & $\mathbf{3 3 3}$ & $\mathbf{1 6 1}$ \\
\hline
\end{tabular}




\section{DEMANDA QUÍMICA DE OXIGÊNIO - DQO}

TABELA B7: Valores de DQO no período seco (valores em mg/L)

\begin{tabular}{ccccc}
\hline Data & $\begin{array}{c}\mathbf{1}^{\mathbf{a}} \\
\text { ampliação }\end{array}$ & $\begin{array}{c}\mathbf{2}^{\mathbf{a}} \\
\text { ampliação }\end{array}$ & $\begin{array}{c}\mathbf{3}^{\mathbf{a}} \\
\text { ampliação }\end{array}$ & $\begin{array}{c}\text { Aterro } \\
\text { Antigo }\end{array}$ \\
\hline 03.06 .09 & 5104 & 3767 & 3974 & \\
17.06 .09 & 5670 & 4266 & 3099 & \\
25.06 .09 & 5434 & 3986 & 3523 & 3253 \\
01.07 .09 & 5267 & 3957 & 3748 & 3286 \\
07.07 .09 & 7069 & 5158 & 3573 & 3222 \\
14.07 .09 & 5775 & 4150 & 3233 & 3241 \\
04.08 .09 & 4852 & 4435 & 2714 & 3378 \\
11.08 .09 & 5262 & 4354 & 2857 & 3485 \\
18.08 .09 & 5101 & 4007 & 2466 & 3045 \\
24.08 .09 & 1577 & 3188 & 2128 & 1034 \\
01.09 .09 & 3421 & 3469 & 2447 & 1547 \\
\hline MÉDIA & $\mathbf{4 9 5 7}$ & $\mathbf{4 0 6 7}$ & $\mathbf{3 0 6 9}$ & $\mathbf{2 8 3 2}$ \\
\hline
\end{tabular}

TABELA B8: Valores de DQO no período chuvoso (valores em mg/L)

\begin{tabular}{ccccc}
\hline \multirow{2}{*}{ Data } & $\begin{array}{c}\mathbf{1}^{\mathbf{a}} \\
\text { ampliação }\end{array}$ & $\begin{array}{c}\mathbf{2}^{\mathbf{a}} \\
\text { ampliação }\end{array}$ & $\begin{array}{c}\mathbf{3}^{\mathbf{a}} \\
\text { ampliação }\end{array}$ & $\begin{array}{c}\text { Aterro } \\
\text { Antigo }\end{array}$ \\
\hline 27.10 .09 & 2412 & 3350 & 2704 & 1702 \\
10.11 .09 & 1911 & 3887 & 2271 & 1530 \\
17.11 .09 & 2906 & 3778 & 2916 & 1713 \\
24.11 .09 & 2083 & 3485 & 2188 & 1549 \\
01.12 .09 & 1794 & 3969 & 3247 & 1305 \\
\hline MÉDIA & $\mathbf{2 2 2 1}$ & $\mathbf{3 6 9 4}$ & $\mathbf{2 6 6 5}$ & $\mathbf{1 5 6 0}$ \\
\hline
\end{tabular}


NITROGÊNIO TOTAL KJELDAHL - NTK

TABELA B9: Valores de NTK no período seco (valores em mg/L)

\begin{tabular}{ccccc}
\hline Data & $\begin{array}{c}\mathbf{1}^{\mathbf{a}} \\
\text { ampliação }\end{array}$ & $\begin{array}{c}\mathbf{2}^{\mathbf{a}} \\
\text { ampliação }\end{array}$ & $\begin{array}{c}\mathbf{3}^{\text {a }} \\
\text { ampliação }\end{array}$ & $\begin{array}{c}\text { Aterro } \\
\text { Antigo }\end{array}$ \\
\hline 03.06 .09 & 2528 & 2469 & 1287 & \\
17.06 .09 & 2608 & 2420 & 969 & \\
25.06 .09 & 2865 & 3509 & 1800 & 1508 \\
01.07 .09 & 2976 & 2590 & 1784 & 1630 \\
07.07 .09 & 2998 & 2810 & 1983 & 1387 \\
14.07 .09 & 2612 & 2909 & 1762 & 1497 \\
04.08 .09 & 2921 & 2876 & 1409 & 1464 \\
11.08 .09 & 2656 & 2876 & 1431 & 1398 \\
18.08 .09 & 3229 & 3207 & 1872 & 1508 \\
24.08 .09 & 1034 & 1619 & 891 & 736 \\
01.09 .09 & 1773 & 2225 & 1188 & 1056 \\
\hline MÉDIA & $\mathbf{2 5 6 4}$ & $\mathbf{2 6 8 3}$ & $\mathbf{1 4 8 9}$ & $\mathbf{1 3 5 4}$ \\
\hline
\end{tabular}

\section{N AMONIACAL}

TABELA B10: Valores de $\mathrm{N}$ amoniacal no período seco (valores em $\mathrm{mg} / \mathrm{L}$ )

\begin{tabular}{ccccc}
\hline Data & $\begin{array}{c}\mathbf{1}^{\mathbf{a}} \\
\text { ampliação }\end{array}$ & $\begin{array}{c}\mathbf{2}^{\mathbf{a}} \\
\text { ampliação }\end{array}$ & $\begin{array}{c}\mathbf{3}^{\mathbf{a}} \\
\text { ampliação }\end{array}$ & $\begin{array}{c}\text { Aterro } \\
\text { Antigo }\end{array}$ \\
\hline 03.06 .09 & 2383 & 2257 & 1072 & \\
17.06 .09 & 2462 & 2751 & 826 & \\
25.06 .09 & 2602 & 2625 & 1239 & 1241 \\
01.07 .09 & 2538 & 2485 & 1608 & 1286 \\
07.07 .09 & 2651 & 1851 & 1661 & 1184 \\
14.07 .09 & 2643 & 2565 & 1471 & 1239 \\
04.08 .09 & 2552 & 2554 & 1151 & 1186 \\
11.08 .09 & 2574 & 2588 & 991 & 1106 \\
18.08 .09 & 2588 & 2494 & 1062 & 985 \\
24.08 .09 & 886 & 1404 & 651 & 541 \\
01.09 .09 & 1664 & 1851 & 897 & 800 \\
\hline MÉDIA & $\mathbf{2 2 9 0}$ & $\mathbf{2 2 6 7}$ & $\mathbf{1 1 4 8}$ & $\mathbf{1 0 6 3}$ \\
\hline
\end{tabular}


Os valores destacados na tabela anterior apresentaram erro durante a execução da análise, já que não é possível que os valores de $\mathrm{N}$ amoniacal sejam maiores que o de NTK. Estes não foram considerados na média.

\section{SÓLIDOS TOTAIS}

TABELA B11: Valores de sólidos totais no período seco (valores em mg/L)

\begin{tabular}{ccccc}
\hline Data & $\begin{array}{c}\mathbf{1}^{\mathbf{a}} \\
\text { ampliação }\end{array}$ & $\begin{array}{c}\mathbf{2}^{\mathbf{a}} \\
\text { ampliação }\end{array}$ & $\begin{array}{c}\mathbf{3}^{\mathbf{a}} \\
\text { ampliação }\end{array}$ & $\begin{array}{c}\text { Aterro } \\
\text { Antigo }\end{array}$ \\
\hline 03.06 .09 & 18043 & 10575 & 13352 & \\
17.06 .09 & 18077 & 14557 & 13321 & \\
25.06 .09 & 15815 & 11300 & 14028 & 9355 \\
01.07 .09 & 14915 & 9395 & 12669 & 14387 \\
07.07 .09 & 17880 & 16245 & 14355 & 9316 \\
14.07 .09 & 15320 & 12357 & 13643 & 10594 \\
04.08 .09 & 18026 & 15102 & 12777 & 9152 \\
11.08 .09 & 18594 & 16321 & 12282 & 9477 \\
18.08 .09 & 19880 & 14835 & 14018 & 9713 \\
24.08 .09 & 4851 & 7065 & 7089 & 3766 \\
01.09 .09 & 8590 & 8913 & 10440 & 5027 \\
\hline MÉDIA & $\mathbf{1 5 4 5 4}$ & $\mathbf{1 2 4 2 4}$ & $\mathbf{1 2 5 4 3}$ & $\mathbf{8 9 7 6}$ \\
\hline
\end{tabular}

TABELA B12: Valores de sólidos totais no período chuvoso (valores em mg/L)

\begin{tabular}{ccccc}
\hline \multirow{2}{*}{ Data } & $\begin{array}{c}\mathbf{1}^{\mathbf{a}} \\
\text { ampliação }\end{array}$ & $\begin{array}{c}\mathbf{2}^{\mathbf{a}} \\
\text { ampliação }\end{array}$ & $\begin{array}{c}\mathbf{3}^{\mathbf{a}} \\
\text { ampliação }\end{array}$ & $\begin{array}{c}\text { Aterro } \\
\text { Antigo }\end{array}$ \\
\hline 27.10 .09 & 7287 & 11984 & 12889 & 5902 \\
10.11 .09 & 5054 & 11670 & 9656 & 4893 \\
17.11 .09 & 8060 & 11450 & 11845 & 5080 \\
24.11 .09 & 6072 & 11038 & 8288 & 5298 \\
01.12 .09 & 5096 & 11462 & 9643 & 3538 \\
\hline MÉDIA & $\mathbf{6 3 1 4}$ & $\mathbf{1 1 5 2 1}$ & $\mathbf{1 0 4 6 4}$ & $\mathbf{4 9 4 2}$ \\
\hline
\end{tabular}




\section{SÓLIDOS TOTAIS FIXOS}

TABELA B13: Valores de sólidos totais fixos no período seco (valores em

$$
\mathrm{mg} / \mathrm{L} \text { ) }
$$

\begin{tabular}{ccccc}
\hline Data & $\begin{array}{c}\mathbf{1}^{\mathbf{a}} \\
\text { ampliação }\end{array}$ & $\begin{array}{c}\mathbf{2}^{\mathbf{a}} \\
\text { ampliação }\end{array}$ & $\begin{array}{c}\mathbf{3}^{\text {a }} \\
\text { ampliação }\end{array}$ & $\begin{array}{c}\text { Aterro } \\
\text { Antigo }\end{array}$ \\
\hline 03.06 .09 & 9209 & 8227 & 10507 & \\
17.06 .09 & 9395 & 9266 & 10434 & \\
25.06 .09 & 9626 & 8837 & 11206 & 6865 \\
01.07 .09 & 8854 & 7115 & 9708 & 11202 \\
07.07 .09 & 9293 & 8982 & 11101 & 6851 \\
14.07 .09 & 10141 & 9737 & 11008 & 7830 \\
04.08 .09 & 9080 & 8835 & 9220 & 6793 \\
11.08 .09 & 9018 & 8792 & 9573 & 6934 \\
18.08 .09 & 9965 & 9129 & 9880 & 7286 \\
24.08 .09 & 3250 & 5359 & 4871 & 2694 \\
01.09 .09 & 5932 & 6545 & 7923 & 3795 \\
\hline MÉDIA & $\mathbf{8 5 2 4}$ & $\mathbf{8 2 5 7}$ & $\mathbf{9 5 8 5}$ & $\mathbf{6 6 9 4}$ \\
\hline
\end{tabular}

TABELA B14: Valores de sólidos totais fixos no período chuvoso (valores em

$$
\mathrm{mg} / \mathrm{L} \text { ) }
$$

\begin{tabular}{ccccc}
\hline Data & $\begin{array}{c}\mathbf{1}^{\mathbf{a}} \\
\text { ampliação }\end{array}$ & $\begin{array}{c}\mathbf{2}^{\mathbf{a}} \\
\text { ampliação }\end{array}$ & $\begin{array}{c}\mathbf{3}^{\mathbf{a}} \\
\text { ampliação }\end{array}$ & $\begin{array}{c}\text { Aterro } \\
\text { Antigo }\end{array}$ \\
\hline 27.10 .09 & 5398 & 8545 & 8514 & 4666 \\
10.11 .09 & 4085 & 8223 & 6968 & 3629 \\
17.11 .09 & 5949 & 8779 & 8976 & 3680 \\
24.11 .09 & 4318 & 8116 & 5969 & 3847 \\
01.12 .09 & 3624 & 8209 & 6749 & 2608 \\
\hline MÉDIA & $\mathbf{4 6 7 5}$ & $\mathbf{8 3 7 4}$ & $\mathbf{7 4 3 5}$ & $\mathbf{3 6 8 6}$ \\
\hline
\end{tabular}




\section{SÓLIDOS TOTAIS VOLÁTEIS}

TABELA B15: Valores de sólidos totais voláteis no período seco (valores em

$$
\mathrm{mg} / \mathrm{L})
$$

\begin{tabular}{ccccc}
\hline Data & $\begin{array}{c}\mathbf{1}^{\mathbf{a}} \\
\text { ampliação }\end{array}$ & $\begin{array}{c}\mathbf{2}^{\mathbf{a}} \\
\text { ampliação }\end{array}$ & $\begin{array}{c}\mathbf{3}^{\mathbf{a}} \\
\text { ampliação }\end{array}$ & $\begin{array}{c}\text { Aterro } \\
\text { Antigo }\end{array}$ \\
\hline 03.06 .09 & 8834 & 2348 & 2845 & \\
17.06 .09 & 8682 & 5291 & 2887 & \\
25.06 .09 & 6189 & 2463 & 2822 & 2490 \\
01.07 .09 & 6061 & 2280 & 2961 & 3185 \\
07.07 .09 & 8587 & 7263 & 3254 & 2465 \\
14.07 .09 & 5179 & 2620 & 2635 & 2764 \\
04.08 .09 & 8946 & 6267 & 3557 & 2359 \\
11.08 .09 & 9576 & 7529 & 2709 & 2543 \\
18.08 .09 & 9915 & 5706 & 4138 & 2427 \\
24.08 .09 & 1601 & 1706 & 2218 & 1072 \\
01.09 .09 & 2658 & 2368 & 2517 & 1232 \\
\hline MÉDIA & $\mathbf{6 9 3 0}$ & $\mathbf{4 1 6 7}$ & $\mathbf{2 9 5 8}$ & $\mathbf{2 2 8 2}$ \\
\hline
\end{tabular}

TABELA B16: Valores de sólidos totais voláteis no período chuvoso (valores em $\mathrm{mg} / \mathrm{L})$

\begin{tabular}{ccccc}
\hline Data & $\begin{array}{c}\mathbf{1}^{\mathbf{a}} \\
\text { ampliação }\end{array}$ & $\begin{array}{c}\mathbf{2}^{\mathbf{a}} \\
\text { ampliação }\end{array}$ & $\begin{array}{c}\mathbf{3}^{\mathbf{a}} \\
\text { ampliação }\end{array}$ & $\begin{array}{c}\text { Aterro } \\
\text { Antigo }\end{array}$ \\
\hline 27.10 .09 & 1889 & 3439 & 4375 & 1236 \\
10.11 .09 & 969 & 3447 & 2688 & 1264 \\
17.11 .09 & 2111 & 2671 & 2869 & 1400 \\
24.11 .09 & 1754 & 2922 & 2319 & 1451 \\
01.12 .09 & 1472 & 3253 & 2894 & 930 \\
\hline MÉDIA & $\mathbf{1 6 3 9}$ & $\mathbf{3 1 4 6}$ & $\mathbf{3 0 2 9}$ & $\mathbf{1 2 5 6}$ \\
\hline
\end{tabular}




\section{SÓLIDOS SUSPENSOS TOTAIS}

TABELA B17: Valores de sólidos suspensos totais no período seco (valores em mg/L)

\begin{tabular}{ccccc}
\hline Data & $\begin{array}{c}\mathbf{1}^{\mathbf{a}} \\
\text { ampliação }\end{array}$ & $\begin{array}{c}\mathbf{2}^{\mathbf{a}} \\
\text { ampliação }\end{array}$ & $\begin{array}{c}\mathbf{3}^{\mathbf{a}} \\
\text { ampliação }\end{array}$ & $\begin{array}{c}\text { Aterro } \\
\text { Antigo }\end{array}$ \\
\hline 03.06 .09 & 87 & 59 & 430 & \\
17.06 .09 & 113 & 66 & 350 & \\
25.06 .09 & 95 & 144 & 251 & 167 \\
01.07 .09 & 93 & 89 & 315 & 100 \\
07.07 .09 & 87 & 77 & 305 & 206 \\
14.07 .09 & 76 & 117 & 285 & 164 \\
04.08 .09 & 91 & 81 & 159 & 110 \\
11.08 .09 & 86 & 76 & 258 & 368 \\
18.08 .09 & 93 & 90 & 235 & 180 \\
24.08 .09 & 53 & 90 & 234 & 40 \\
01.09 .09 & 57 & 165 & 157 & 43 \\
\hline MÉDIA & $\mathbf{8 5}$ & $\mathbf{9 6}$ & $\mathbf{2 7 1}$ & $\mathbf{1 5 3}$ \\
\hline
\end{tabular}

TABELA B18: Valores de sólidos suspensos totais no período chuvoso (valores em

$$
\mathrm{mg} / \mathrm{L} \text { ) }
$$

\begin{tabular}{ccccc}
\hline Data & $\begin{array}{c}\mathbf{1}^{\mathbf{a}} \\
\text { ampliação }\end{array}$ & $\begin{array}{c}\mathbf{2}^{\mathbf{a}} \\
\text { ampliação }\end{array}$ & $\begin{array}{c}\mathbf{3}^{\mathbf{a}} \\
\text { ampliação }\end{array}$ & $\begin{array}{c}\text { Aterro } \\
\text { Antigo }\end{array}$ \\
\hline 27.10 .09 & 49 & 116 & 173 & 150 \\
10.11 .09 & 21 & 97 & 143 & 478 \\
17.11 .09 & 37 & 158 & 150 & 640 \\
24.11 .09 & 66 & 111 & 206 & 686 \\
01.12 .09 & 30 & 73 & 139 & 103 \\
\hline MÉDIA & $\mathbf{4 1}$ & $\mathbf{1 1 1}$ & $\mathbf{1 6 2}$ & $\mathbf{4 1 1}$ \\
\hline
\end{tabular}




\section{SÓLIDOS SUSPENSOS FIXOS}

TABELA B19: Valores de sólidos suspensos fixos no período seco (valores em $\mathrm{mg} / \mathrm{L})$

\begin{tabular}{ccccc}
\hline Data & $\begin{array}{c}\mathbf{1}^{\mathbf{a}} \\
\text { ampliação }\end{array}$ & $\begin{array}{c}\mathbf{2}^{\mathbf{a}} \\
\text { ampliação }\end{array}$ & $\begin{array}{c}\mathbf{3}^{\mathbf{a}} \\
\text { ampliação }\end{array}$ & $\begin{array}{c}\text { Aterro } \\
\text { Antigo }\end{array}$ \\
\hline 03.06 .09 & 33 & 21 & 95 & \\
17.06 .09 & 23 & 28 & 110 & \\
25.06 .09 & 30 & 22 & 56 & 71 \\
01.07 .09 & 18 & 45 & 73 & 45 \\
07.07 .09 & 25 & 23 & 80 & 56 \\
14.07 .09 & 25 & 38 & 75 & 72 \\
04.08 .09 & 19 & 14 & 34 & 40 \\
11.08 .09 & 16 & 21 & 53 & 136 \\
18.08 .09 & 31 & 27 & 43 & 52 \\
24.08 .09 & 8 & 3 & 11 & 4 \\
01.09 .09 & 20 & 35 & 35 & 10 \\
\hline MÉDIA & $\mathbf{2 2}$ & $\mathbf{2 5}$ & $\mathbf{6 0}$ & $\mathbf{5 4}$ \\
\hline
\end{tabular}

TABELA B20: Valores de sólidos suspensos fixos no período chuvoso (valores em $\mathrm{mg} / \mathrm{L})$

\begin{tabular}{ccccc}
\hline Data & $\begin{array}{c}\mathbf{1}^{\mathbf{a}} \\
\text { ampliação }\end{array}$ & $\begin{array}{c}\mathbf{2}^{\mathbf{a}} \\
\text { ampliação }\end{array}$ & $\begin{array}{c}\mathbf{3}^{\mathbf{a}} \\
\text { ampliação }\end{array}$ & $\begin{array}{c}\text { Aterro } \\
\text { Antigo }\end{array}$ \\
\hline 27.10 .09 & 14 & 28 & 39 & 45 \\
10.11 .09 & 4 & 18 & 19 & 205 \\
17.11 .09 & 8 & 36 & 30 & 280 \\
24.11 .09 & 11 & 30 & 36 & 251 \\
01.12 .09 & 2 & 18 & 30 & 38 \\
\hline MÉDIA & $\mathbf{8}$ & $\mathbf{2 6}$ & $\mathbf{3 1}$ & $\mathbf{1 6 4}$ \\
\hline
\end{tabular}




\section{SÓLIDOS SUSPENSOS VOLÁTEIS}

TABELA B21: Valores de sólidos suspensos voláteis no período seco (valores

$$
\text { em mg/L) }
$$

\begin{tabular}{ccccc}
\hline Data & $\begin{array}{c}\mathbf{1}^{\mathbf{a}} \\
\text { ampliação }\end{array}$ & $\begin{array}{c}\mathbf{2}^{\mathbf{a}} \\
\text { ampliação }\end{array}$ & $\begin{array}{c}\mathbf{3}^{\mathbf{a}} \\
\text { ampliação }\end{array}$ & $\begin{array}{c}\text { Aterro } \\
\text { Antigo }\end{array}$ \\
\hline 03.06 .09 & 54 & 38 & 335 & \\
17.06 .09 & 90 & 38 & 240 & \\
25.06 .09 & 65 & 122 & 196 & 96 \\
01.07 .09 & 75 & 44 & 243 & 55 \\
07.07 .09 & 62 & 54 & 225 & 150 \\
14.07 .09 & 51 & 78 & 210 & 92 \\
04.08 .09 & 73 & 67 & 124 & 70 \\
11.08 .09 & 70 & 54 & 205 & 232 \\
18.08 .09 & 62 & 63 & 193 & 128 \\
24.08 .09 & 44 & 87 & 223 & 36 \\
01.09 .09 & 37 & 130 & 122 & 33 \\
\hline MÉDIA & $\mathbf{6 2}$ & $\mathbf{7 0}$ & $\mathbf{2 1 0}$ & $\mathbf{9 9}$ \\
\hline
\end{tabular}

TABELA B22: Valores de sólidos suspensos voláteis no período chuvoso (valores em $\mathrm{mg} / \mathrm{L}$ )

\begin{tabular}{ccccc}
\hline Data & $\begin{array}{c}\mathbf{1}^{\mathbf{a}} \\
\text { ampliação }\end{array}$ & $\begin{array}{c}\mathbf{2}^{\mathbf{a}} \\
\text { ampliação }\end{array}$ & $\begin{array}{c}\mathbf{3}^{\mathbf{a}} \\
\text { ampliação }\end{array}$ & $\begin{array}{c}\text { Aterro } \\
\text { Antigo }\end{array}$ \\
\hline 27.10 .09 & 35 & 88 & 134 & 105 \\
10.11 .09 & 17 & 80 & 124 & 273 \\
17.11 .09 & 29 & 122 & 120 & 360 \\
24.11 .09 & 55 & 81 & 170 & 434 \\
01.12 .09 & 28 & 55 & 109 & 65 \\
\hline MÉDIA & $\mathbf{3 3}$ & $\mathbf{8 5}$ & $\mathbf{1 3 2}$ & $\mathbf{2 4 7}$ \\
\hline
\end{tabular}


ANEXO C - RESULTADOS DOS METAIS 
$1^{\mathrm{a}}$ AMPLIAÇÃO - PERÍODO SECO

\begin{tabular}{|c|c|c|c|c|c|c|c|c|c|c|}
\hline $\begin{array}{c}\text { Data da } \\
\text { coleta }\end{array}$ & $\begin{array}{c}\mathrm{Zn} \\
(\mathrm{mg} / \mathrm{L})\end{array}$ & $\begin{array}{c}\mathrm{Pb} \\
(\mathrm{mg} / \mathrm{L})\end{array}$ & $\begin{array}{c}\mathrm{Cd} \\
(\mathrm{mg} / \mathrm{L})\end{array}$ & $\begin{array}{c}\mathrm{Ni} \\
(\mathrm{mg} / \mathrm{L})\end{array}$ & $\begin{array}{c}\mathrm{Fe} \\
(\mathrm{mg} / \mathrm{L})\end{array}$ & $\begin{array}{c}\mathrm{Mn} \\
(\mathrm{mg} / \mathrm{L})\end{array}$ & $\begin{array}{c}\mathrm{Cu} \\
(\mathrm{mg} / \mathrm{L})\end{array}$ & $\begin{array}{c}\mathrm{Cr} \\
(\mathrm{mg} / \mathrm{L})\end{array}$ & $\begin{array}{c}\mathrm{Na} \\
(\mathrm{mg} / \mathrm{L})\end{array}$ & $\mathrm{K}(\mathrm{mg} / \mathrm{L})$ \\
\hline 03.06 .09 & 0,476 & ND & 0,007 & 0,347 & 5,387 & 0,116 & 0,064 & 0,443 & & \\
\hline 17.06 .09 & 0,504 & 0,22 & 0,038 & 0,391 & 4,290 & 0,108 & 0,034 & 0,412 & & \\
\hline 25.06 .09 & 0,566 & 0,41 & 0,072 & 0,455 & 4,002 & 0,117 & 0,053 & 0,521 & & \\
\hline 01.07 .09 & 0,555 & 0,52 & 0,076 & 0,487 & 4,157 & 0,132 & 0,038 & 0,449 & 2578 & 2162 \\
\hline 07.07 .09 & 0,531 & ND & 0,018 & 0,355 & 3,971 & 0,102 & 0,035 & 0,486 & 2883 & 2266 \\
\hline 14.07 .09 & 0,502 & 0,22 & 0,024 & 0,401 & 4,135 & 0,106 & 0,030 & 0,463 & 2290 & 1923 \\
\hline 04.08 .09 & 0,347 & ND & ND & 0,226 & 2,912 & 0,071 & 0,025 & 0,396 & 2030 & 1781 \\
\hline 11.08 .09 & 0,482 & 0,32 & 0,035 & 0,434 & 3,072 & 0,108 & 0,047 & 0,464 & 2098 & 2011 \\
\hline 18.08 .09 & 0,423 & 0,17 & 0,022 & 0,407 & 4,266 & 0,098 & 0,024 & 0,473 & 4602 & 3828 \\
\hline 24.08 .09 & 0,087 & 0,29 & 0,019 & 0,146 & 2,319 & 0,137 & 0,015 & 0,077 & 895 & 691 \\
\hline 01.09 .09 & 0,278 & 0,58 & 0,037 & 0,339 & 2,802 & 0,142 & 0,012 & 0,218 & 1569 & 1233 \\
\hline
\end{tabular}


$1^{\mathrm{a}}$ AMPLIAÇÃO - PERÍODO CHUVOSO

\begin{tabular}{|c|c|c|c|c|c|c|c|c|c|c|}
\hline $\begin{array}{c}\text { Data da } \\
\text { coleta }\end{array}$ & $\begin{array}{c}\mathrm{Zn} \\
(\mathrm{mg} / \mathrm{L})\end{array}$ & $\begin{array}{c}\mathrm{Pb} \\
(\mathrm{mg} / \mathrm{L})\end{array}$ & $\begin{array}{c}\mathrm{Cd} \\
(\mathrm{mg} / \mathrm{L})\end{array}$ & $\begin{array}{c}\mathrm{Ni} \\
(\mathrm{mg} / \mathrm{L})\end{array}$ & $\begin{array}{c}\mathrm{Fe} \\
(\mathrm{mg} / \mathrm{L})\end{array}$ & $\begin{array}{c}\mathrm{Mn} \\
(\mathrm{mg} / \mathrm{L})\end{array}$ & $\begin{array}{c}\mathrm{Cu} \\
(\mathrm{mg} / \mathrm{L})\end{array}$ & $\begin{array}{c}\mathrm{Cr} \\
(\mathrm{mg} / \mathrm{L})\end{array}$ & $\begin{array}{c}\mathrm{Na} \\
(\mathrm{mg} / \mathrm{L})\end{array}$ & \begin{tabular}{c}
$\mathrm{K}(\mathrm{mg} / \mathrm{L})$ \\
\hline 27.10 .09
\end{tabular} \\
0,177 & 0,23 & 0,051 & 0,239 & 2,927 & 0,106 & 0,019 & 0,209 & 1363 & 1170 \\
\hline 10.11 .09 & 0,148 & 0,14 & 0,017 & 0,151 & 2,458 & 0,121 & 0,014 & 0,042 & 974 & 929 \\
\hline 17.11 .09 & 0,917 & 0,23 & 0,018 & 0,331 & 4,773 & 0,125 & 0,027 & 0,143 & 1579 & 1280 \\
\hline 24.11 .09 & 0,220 & $\mathrm{ND}$ & 0,048 & 0,152 & 3,274 & 0,116 & 0,058 & 0,108 & 1246 & 958 \\
\hline 01.12 .09 & 0,056 & $\mathrm{ND}$ & 0,014 & 0,120 & 2,333 & 0,139 & $\mathrm{ND}$ & 0,057 & 838 & 745 \\
\hline
\end{tabular}


$2^{\mathrm{a}}$ AMPLIAÇÃO - PERÍODO SECO

\begin{tabular}{|c|c|c|c|c|c|c|c|c|c|c|}
\hline $\begin{array}{c}\text { Data da } \\
\text { coleta }\end{array}$ & $\begin{array}{c}\mathrm{Zn} \\
(\mathrm{mg} / \mathrm{L})\end{array}$ & $\begin{array}{c}\mathrm{Pb} \\
(\mathrm{mg} / \mathrm{L})\end{array}$ & $\begin{array}{c}\mathrm{Cd} \\
(\mathrm{mg} / \mathrm{L})\end{array}$ & $\begin{array}{c}\mathrm{Ni} \\
(\mathrm{mg} / \mathrm{L})\end{array}$ & $\begin{array}{c}\mathrm{Fe} \\
(\mathrm{mg} / \mathrm{L})\end{array}$ & $\begin{array}{c}\mathrm{Mn} \\
(\mathrm{mg} / \mathrm{L})\end{array}$ & $\begin{array}{c}\mathrm{Cu} \\
(\mathrm{mg} / \mathrm{L})\end{array}$ & $\begin{array}{c}\mathrm{Cr} \\
(\mathrm{mg} / \mathrm{L})\end{array}$ & $\begin{array}{c}\mathrm{Na} \\
(\mathrm{mg} / \mathrm{L})\end{array}$ & $\mathrm{K}(\mathrm{mg} / \mathrm{L})$ \\
\hline 03.06 .09 & 0,456 & $\mathrm{ND}$ & 0,012 & 0,308 & 7,150 & 0,121 & 0,036 & 0,345 & \\
\hline 17.06 .09 & 0,578 & 0,19 & 0,031 & 0,363 & 7,884 & 0,115 & 0,013 & 0,432 & & \\
\hline 25.06 .09 & 0,529 & 0,48 & 0,070 & 0,449 & 6,510 & 0,114 & 0,031 & 0,419 & & 2290 \\
\hline 01.07 .09 & 0,499 & 0,36 & 0,057 & 0,414 & 6,753 & 0,102 & 0,032 & 0,372 & 2001 \\
\hline 07.07 .09 & 0,569 & 0,05 & 0,122 & 0,344 & 7,582 & 0,103 & 0,017 & 0,387 & 2763 & 2131 \\
\hline 14.07 .09 & 0,481 & 0,07 & 0,029 & 0,340 & 7,342 & 0,100 & 0,026 & 0,344 & 2098 & 1772 \\
\hline 04.08 .09 & 0,349 & $\mathrm{ND}$ & 0,039 & 0,258 & 5,446 & 0,063 & 0,008 & 0,295 & 2006 & 1837 \\
\hline 11.08 .09 & 0,375 & 0,26 & 0,021 & 0,395 & 6,583 & 0,095 & 0,027 & 0,344 & 2030 & 1991 \\
\hline 18.08 .09 & 0,402 & 0,24 & 0,024 & 0,393 & 6,580 & 0,091 & 0,017 & 0,385 & 2008 & 1962 \\
\hline 24.08 .09 & 0,212 & 0,32 & 0,018 & 0,248 & 4,793 & 0,084 & 0,004 & 0,192 & 1381 & 1131 \\
\hline 01.09 .09 & 0,413 & 0,56 & 0,060 & 0,349 & 5,738 & 0,104 & 0,021 & 0,248 & 1877 & 1420 \\
\hline
\end{tabular}


$2^{a}$ AMPLIAÇÃO - PERÍODO CHUVOSO

\begin{tabular}{|c|c|c|c|c|c|c|c|c|c|c|}
\hline $\begin{array}{c}\text { Data da } \\
\text { coleta }\end{array}$ & $\begin{array}{c}\mathrm{Zn} \\
(\mathrm{mg} / \mathrm{L})\end{array}$ & $\begin{array}{c}\mathrm{Pb} \\
(\mathrm{mg} / \mathrm{L})\end{array}$ & $\begin{array}{c}\mathrm{Cd} \\
(\mathrm{mg} / \mathrm{L})\end{array}$ & $\begin{array}{c}\mathrm{Ni} \\
(\mathrm{mg} / \mathrm{L})\end{array}$ & $\begin{array}{c}\mathrm{Fe} \\
(\mathrm{mg} / \mathrm{L})\end{array}$ & $\begin{array}{c}\mathrm{Mn} \\
(\mathrm{mg} / \mathrm{L})\end{array}$ & $\begin{array}{c}\mathrm{Cu} \\
(\mathrm{mg} / \mathrm{L})\end{array}$ & $\begin{array}{c}\mathrm{Cr} \\
(\mathrm{mg} / \mathrm{L})\end{array}$ & $\begin{array}{c}\mathrm{Na} \\
(\mathrm{mg} / \mathrm{L})\end{array}$ & \begin{tabular}{c}
$\mathrm{K}(\mathrm{mg} / \mathrm{L})$ \\
\hline 27.10 .09
\end{tabular} \\
0,339 & 0,13 & 0,067 & 0,311 & 6,242 & 0,118 & 0,029 & 0,239 & 2064 & 1809 \\
\hline 10.11 .09 & 0,546 & 0,18 & 0,023 & 0,349 & 6,877 & 0,142 & 0,020 & 0,222 & 1942 & 1763 \\
\hline 17.11 .09 & 1,139 & 0,45 & 0,026 & 0,491 & 7,133 & 0,158 & 0,030 & 0,265 & 2417 & 1809 \\
\hline 24.11 .09 & 0,431 & 0,05 & 0,015 & 0,306 & 7,160 & 0,141 & 0,014 & 0,245 & 2404 & 1680 \\
\hline 01.12 .09 & 0,348 & 0,24 & 0,034 & 0,328 & 7,639 & 0,125 & $\mathrm{ND}$ & 0,273 & 1877 & 1680 \\
\hline
\end{tabular}


$3^{\mathrm{a}}$ AMPLIAÇÃO - PERÍODO SECO

\begin{tabular}{|c|c|c|c|c|c|c|c|c|c|c|}
\hline $\begin{array}{l}\text { Data da } \\
\text { coleta }\end{array}$ & $\begin{array}{c}\mathrm{Zn} \\
(\mathrm{mg} / \mathrm{L})\end{array}$ & $\begin{array}{c}\mathrm{Pb} \\
(\mathrm{mg} / \mathrm{L})\end{array}$ & $\begin{array}{c}\mathrm{Cd} \\
(\mathrm{mg} / \mathrm{L})\end{array}$ & $\begin{array}{c}\mathrm{Ni} \\
(\mathrm{mg} / \mathrm{L})\end{array}$ & $\begin{array}{c}\mathrm{Fe} \\
(\mathrm{mg} / \mathrm{L})\end{array}$ & $\begin{array}{c}\mathrm{Mn} \\
(\mathrm{mg} / \mathrm{L})\end{array}$ & $\begin{array}{c}\mathrm{Cu} \\
(\mathrm{mg} / \mathrm{L})\end{array}$ & $\begin{array}{c}\mathrm{Cr} \\
(\mathrm{mg} / \mathrm{L})\end{array}$ & $\begin{array}{c}\mathrm{Na} \\
(\mathrm{mg} / \mathrm{L})\end{array}$ & $\mathrm{K}(\mathrm{mg} / \mathrm{L})$ \\
\hline 03.06 .09 & 0,424 & 0,28 & 0,067 & 0,327 & 7,671 & 0,064 & 0,057 & 0,079 & & \\
\hline 17.06 .09 & 0,274 & 0,26 & 0,048 & 0,341 & 6,975 & 0,065 & 0,027 & 0,054 & & \\
\hline 25.06 .09 & 0,380 & 0,52 & 0,101 & 0,377 & 10,810 & 0,129 & 0,051 & 0,096 & & \\
\hline 01.07 .09 & 0,416 & 0,55 & 0,094 & 0,374 & 8,450 & 0,133 & 0,050 & 0,116 & 2913 & 2843 \\
\hline 07.07 .09 & 0,305 & 0,21 & 0,026 & 0,306 & 8,372 & 0,072 & 0,036 & 0,086 & 3387 & 2771 \\
\hline 14.07 .09 & 0,310 & 0,20 & 0,029 & 0,362 & 10,072 & 0,071 & 0,031 & 0,117 & 2550 & 2395 \\
\hline 04.08 .09 & 0,207 & ND & ND & 0,197 & 5,346 & 0,072 & 0,025 & 0,035 & 1974 & 1923 \\
\hline 11.08 .09 & 0,277 & 0,34 & 0,054 & 0,350 & 3,601 & 0,085 & 0,045 & 0,072 & 3651 & 2298 \\
\hline 18.08 .09 & 0,284 & 0,50 & 0,061 & 0,382 & 4,253 & 0,087 & 0,034 & 0,070 & 2145 & 2266 \\
\hline 24.08 .09 & 0,115 & 0,26 & 0,025 & 0,171 & 6,604 & 0,361 & 0,017 & 0,043 & 1181 & 1025 \\
\hline 01.09 .09 & 0,174 & 0,57 & 0,045 & 0,319 & 5,404 & 0,113 & 0,007 & 0,052 & 2192 & 1818 \\
\hline
\end{tabular}


$3^{\mathrm{a}}$ AMPLIAÇÃO - PERÍODO CHUVOSO

\begin{tabular}{|c|c|c|c|c|c|c|c|c|c|c|}
\hline $\begin{array}{c}\text { Data da } \\
\text { coleta }\end{array}$ & $\begin{array}{c}\mathrm{Zn} \\
(\mathrm{mg} / \mathrm{L})\end{array}$ & $\begin{array}{c}\mathrm{Pb} \\
(\mathrm{mg} / \mathrm{L})\end{array}$ & $\begin{array}{c}\mathrm{Cd} \\
(\mathrm{mg} / \mathrm{L})\end{array}$ & $\begin{array}{c}\mathrm{Ni} \\
(\mathrm{mg} / \mathrm{L})\end{array}$ & $\begin{array}{c}\mathrm{Fe} \\
(\mathrm{mg} / \mathrm{L})\end{array}$ & $\begin{array}{c}\mathrm{Mn} \\
(\mathrm{mg} / \mathrm{L})\end{array}$ & $\begin{array}{c}\mathrm{Cu} \\
(\mathrm{mg} / \mathrm{L})\end{array}$ & $\begin{array}{c}\mathrm{Cr} \\
(\mathrm{mg} / \mathrm{L})\end{array}$ & $\begin{array}{c}\mathrm{Na} \\
(\mathrm{mg} / \mathrm{L})\end{array}$ & $\begin{array}{c}\mathrm{K}(\mathrm{mg} / \mathrm{L}) \\
27.10 .09\end{array}$ \\
0,227 & 0,24 & 0,059 & 0,267 & 3,711 & 0,074 & 0,043 & 0,135 & 2008 & 1942 \\
\hline 10.11 .09 & 0,190 & 0,07 & 0,018 & 0,179 & 3,836 & 0,146 & 0,022 & 0,018 & 1598 & 1609 \\
\hline 17.11 .09 & 1,092 & 0,52 & 0,024 & 0,379 & 5,323 & 0,091 & 0,039 & 0,078 & 2216 & 2080 \\
\hline 24.11 .09 & 0,144 & 0,03 & 0,019 & 0,167 & 4,092 & 0,142 & 0,022 & 0,056 & 1588 & 1321 \\
\hline 01.12 .09 & 0,117 & 0,09 & 0,033 & 0,179 & 3,889 & 0,174 & 0,004 & 0,074 & 1532 & 1583 \\
\hline
\end{tabular}


ATERRO ANTIGO - PERÍODO SECO

\begin{tabular}{|c|c|c|c|c|c|c|c|c|c|c|}
\hline $\begin{array}{c}\text { Data da } \\
\text { coleta }\end{array}$ & $\begin{array}{c}\mathrm{Zn} \\
(\mathrm{mg} / \mathrm{L})\end{array}$ & $\begin{array}{c}\mathrm{Pb} \\
(\mathrm{mg} / \mathrm{L})\end{array}$ & $\begin{array}{c}\mathrm{Cd} \\
(\mathrm{mg} / \mathrm{L})\end{array}$ & $\begin{array}{c}\mathrm{Ni} \\
(\mathrm{mg} / \mathrm{L})\end{array}$ & $\begin{array}{c}\mathrm{Fe} \\
(\mathrm{mg} / \mathrm{L})\end{array}$ & $\begin{array}{c}\mathrm{Mn} \\
(\mathrm{mg} / \mathrm{L})\end{array}$ & $\begin{array}{c}\mathrm{Cu} \\
(\mathrm{mg} / \mathrm{L})\end{array}$ & $\begin{array}{c}\mathrm{Cr} \\
(\mathrm{mg} / \mathrm{L})\end{array}$ & $\begin{array}{c}\mathrm{Na} \\
(\mathrm{mg} / \mathrm{L})\end{array}$ & $\mathrm{K}(\mathrm{mg} / \mathrm{L})$ \\
\hline 03.06 .09 & & & & & & & & & & \\
\hline 17.06 .09 & & & & & & & & & & \\
\hline 25.06 .09 & 1,057 & 0,42 & 0,106 & 0,490 & 146,600 & 3,226 & 0,156 & 0,677 & & 2456 \\
\hline 01.07 .09 & 0,581 & 0,47 & 0,072 & 0,432 & 15,610 & 0,200 & 0,057 & 0,247 & 2214 \\
\hline 07.07 .09 & 0,498 & 0,05 & 0,014 & 0,380 & 32,542 & 0,794 & 0,115 & 0,461 & 2064 & 1378 \\
\hline 14.07 .09 & 0,706 & 0,17 & 0,027 & 0,421 & 52,362 & 1,344 & 0,132 & 0,493 & 1764 & 1256 \\
\hline 04.08 .09 & 0,382 & $\mathrm{ND}$ & $\mathrm{ND}$ & 0,333 & 12,376 & 0,396 & 0,095 & 0,308 & 1542 & 1201 \\
\hline 11.08 .09 & 0,526 & 0,13 & 0,015 & 0,486 & 17,769 & 0,616 & 0,137 & 0,341 & 3038 & 1412 \\
\hline 18.08 .09 & 0,496 & 0,41 & 0,041 & 0,504 & 9,361 & 0,577 & 0,124 & 0,292 & 1794 & 1378 \\
\hline 24.08 .09 & 0,126 & 0,39 & 0,030 & 0,178 & 2,762 & 0,293 & 0,028 & 0,047 & 703 & 468 \\
\hline 01.09 .09 & 0,137 & 0,26 & 0,021 & 0,210 & 6,652 & 0,310 & 0,032 & 0,084 & 1004 & 698 \\
\hline
\end{tabular}


ATERRO ANTIGO - PERÍODO CHUVOSO

\begin{tabular}{|c|c|c|c|c|c|c|c|c|c|c|}
\hline $\begin{array}{c}\text { Data da } \\
\text { coleta }\end{array}$ & $\begin{array}{c}\mathrm{Zn} \\
(\mathrm{mg} / \mathrm{L})\end{array}$ & $\begin{array}{c}\mathrm{Pb} \\
(\mathrm{mg} / \mathrm{L})\end{array}$ & $\begin{array}{c}\mathrm{Cd} \\
(\mathrm{mg} / \mathrm{L})\end{array}$ & $\begin{array}{c}\mathrm{Ni} \\
(\mathrm{mg} / \mathrm{L})\end{array}$ & $\begin{array}{c}\mathrm{Fe} \\
(\mathrm{mg} / \mathrm{L})\end{array}$ & $\begin{array}{c}\mathrm{Mn} \\
(\mathrm{mg} / \mathrm{L})\end{array}$ & $\begin{array}{c}\mathrm{Cu} \\
(\mathrm{mg} / \mathrm{L})\end{array}$ & $\begin{array}{c}\mathrm{Cr} \\
(\mathrm{mg} / \mathrm{L})\end{array}$ & $\begin{array}{c}\mathrm{Na} \\
(\mathrm{mg} / \mathrm{L})\end{array}$ & \begin{tabular}{c}
$\mathrm{K}(\mathrm{mg} / \mathrm{L})$ \\
\hline 27.10 .09
\end{tabular} \\
0,411 & 0,08 & 0,035 & 0,252 & 64,872 & 1,594 & 0,084 & 0,292 & 1110 & 872 \\
\hline 10.11 .09 & 0,174 & $\mathrm{ND}$ & 0,011 & 0,139 & 7,327 & 0,559 & 0,044 & 0,064 & 916 & 780 \\
\hline 17.11 .09 & 0,569 & 0,50 & 0,014 & 0,327 & 14,983 & 1,034 & 0,060 & 0,121 & 974 & 752 \\
\hline 24.11 .09 & 0,202 & 0,03 & 0,018 & 0,185 & 22,210 & 1,080 & 0,051 & 0,105 & 1134 & 773 \\
\hline 01.12 .09 & 0,104 & 0,09 & 0,014 & 0,150 & 9,779 & 0,444 & 0,029 & 0,062 & 599 & 506 \\
\hline
\end{tabular}

